\title{
Expression and functional analysis of murine Brunol1 and Brunol4, members of Elav/Bruno family
}

\author{
Dissertation \\ zur Erlangung des Doktorgrades \\ der Mathematisch-Naturwissenschaftlichen Fakultäten \\ der Georg-August-Universität zu Göttingen
}

vorgelegt von

Arvind Dev

aus Meerut, Indien

Göttingen 2006 
D7

Referent: $\quad$ Prof. Dr. W. Engel

Korreferentin: $\quad$ Frau PD Dr. S. Hoyer-Fender

Tag der mündlichen Prüfungen 
CONTENTS

CONTENTS

ABBREVIATIONS

\section{INTRODUCTION}

1.1 Elav/Bruno/CELF RNA binding protein family.................................................. 1

1.2 The modular domains of Elav/Bruno RNA binding protein family ............................. 2

1.3 Functional role of ELAV/Bruno like RNA binding proteins ...................................... 3

1.4 Isolation and characterisation of murine Brunol1 and Brunol4 gene, members of

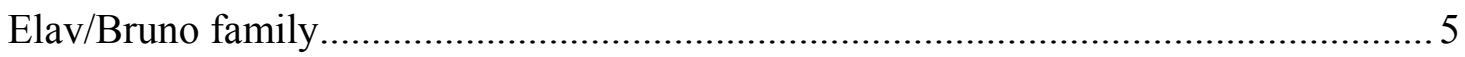

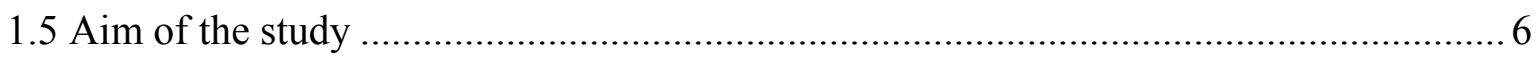

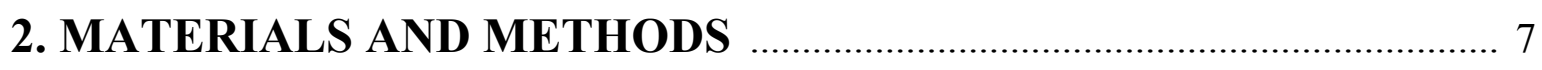

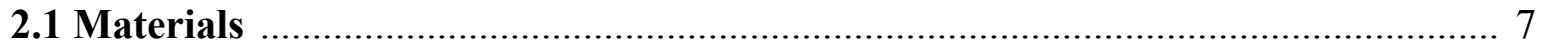

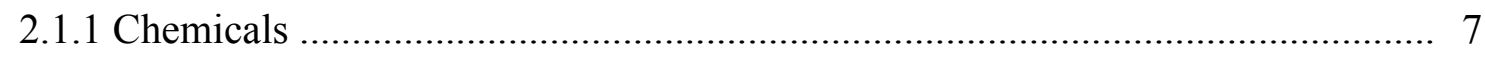

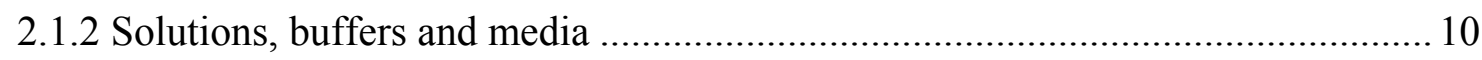

2.1.2.1 Agarose gel electrophoresis ........................................................... $\quad 10$

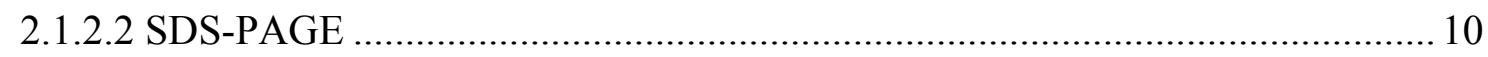

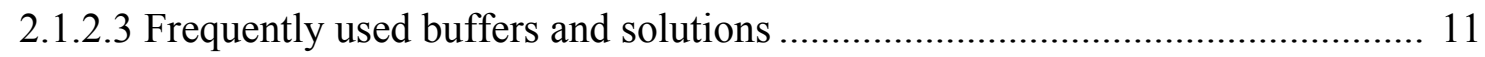

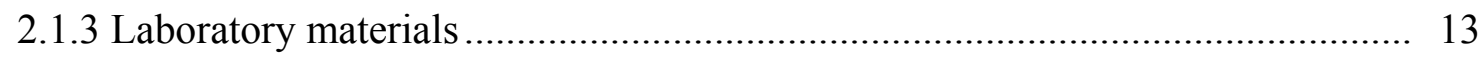

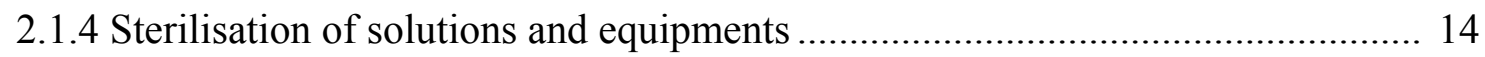

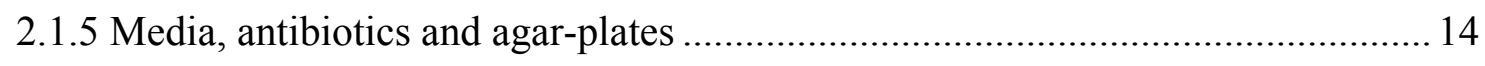

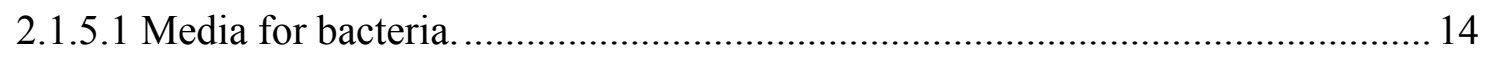

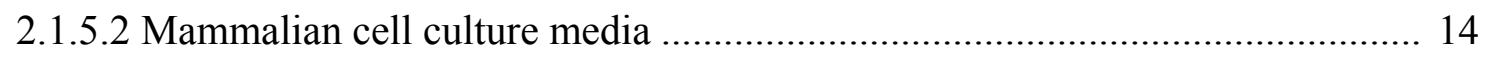

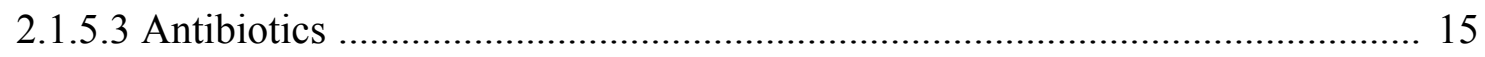

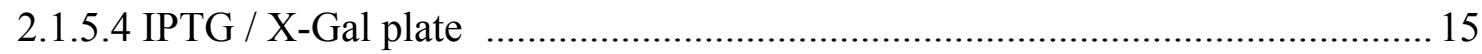

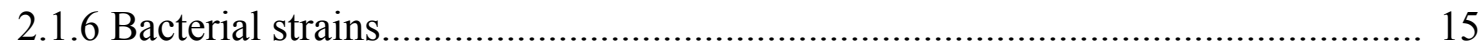

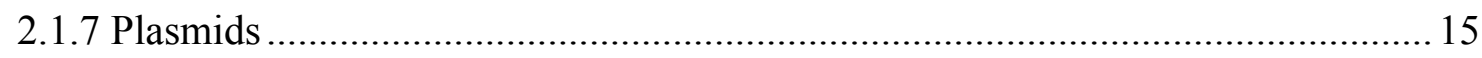

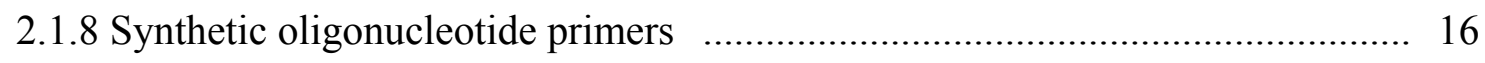

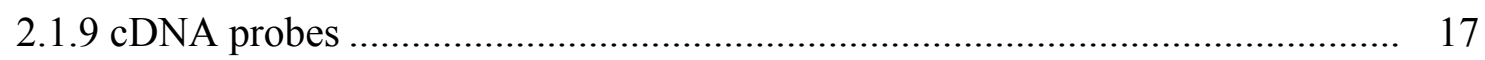

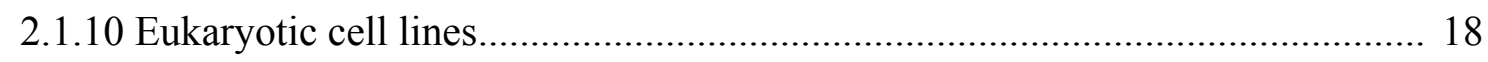

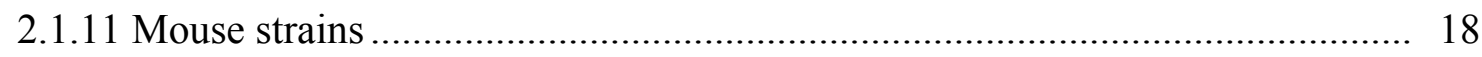

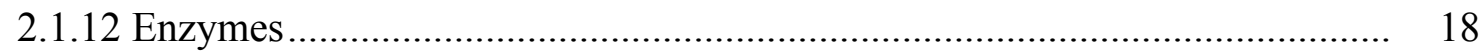




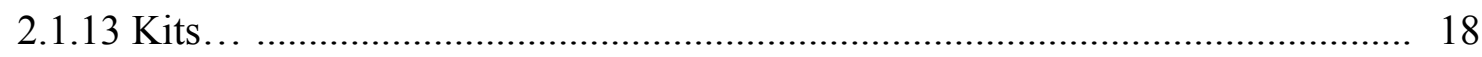

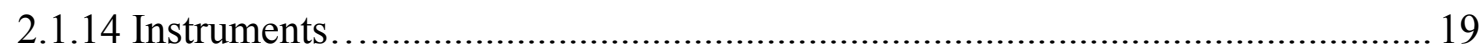

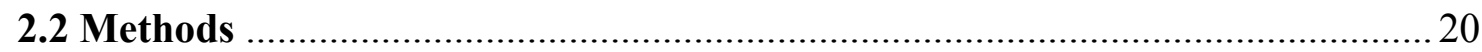

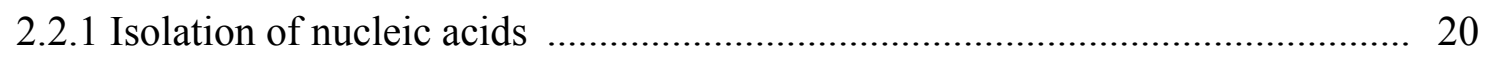

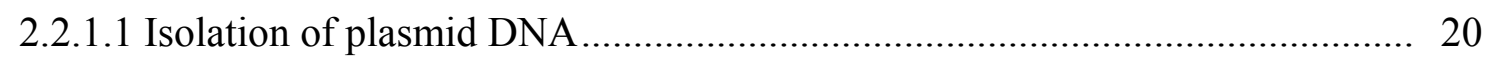

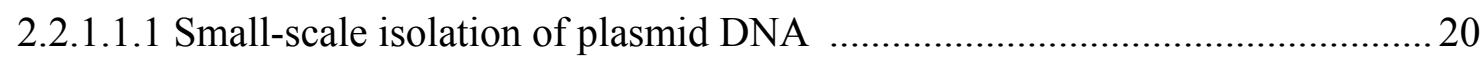

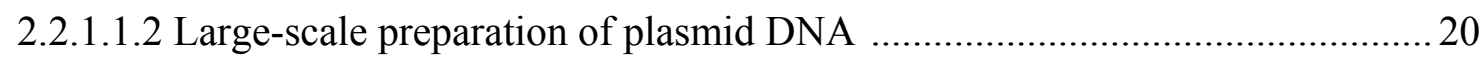

2.2.1.1.3 Endotoxin free preparation of plasmid DNA ……………………………..... 21

2.2.1.2 Isolation of genomic DNA from mouse tail samples ......................................21

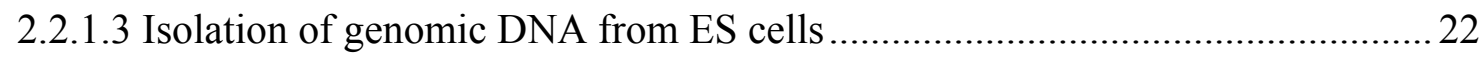

2.2.1.4 Isolation of genomic DNA from cultured blastocysts ........................................ 22

2.2.1.5 Preparation of genomic DNA from preimplantation embryo ............................ 23

2.2.1.6 Isolation of total RNA from tissue samples and cultured cells....................... 23

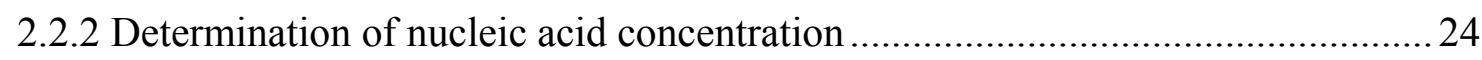

2.2.3 Gel electrophoresis ................................................................................ 24

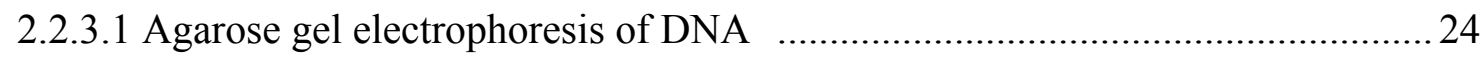

2.2.3.2 Agarose gel electrophoresis of RNA ………………................................ 25

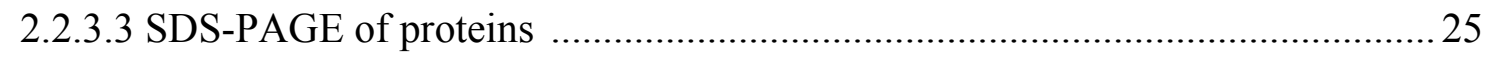

2.2.4 Isolation of DNA fragments from agarose gel ....................................................2 26

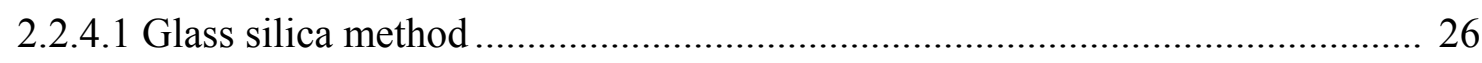

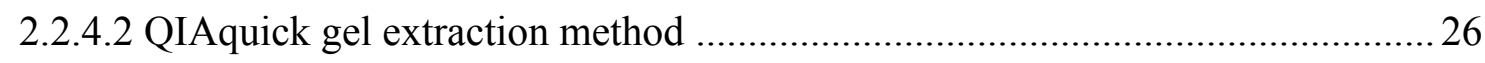

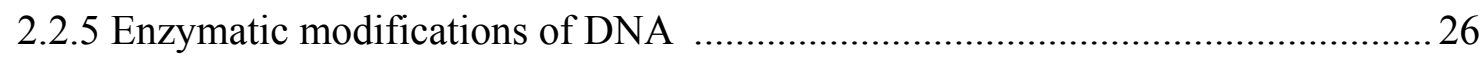

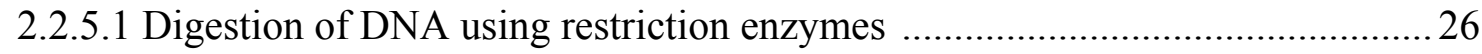

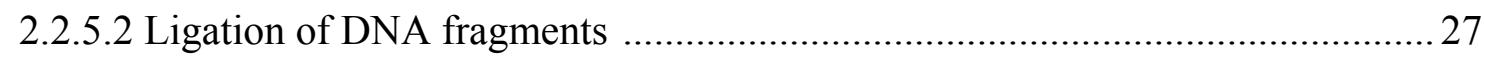

2.2.5.3 Phenol-chloroform extraction and ethanol precipitation ................................... 27

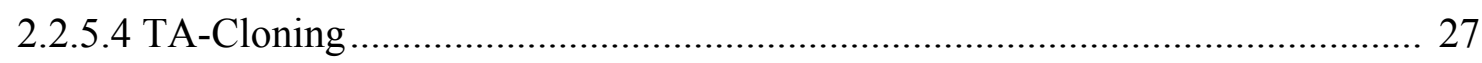

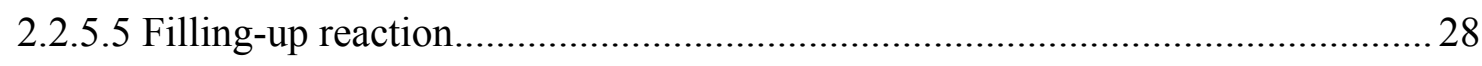

2.2.6 Transformation of competent bacteria ......................................................... 28

2.2.7 Polymerase Chain Reaction (PCR) ............................................................... 28

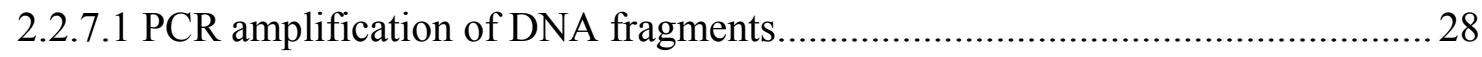

2.2.7.2 Reverse transcription PCR (RT-PCR) ........................................................ 29

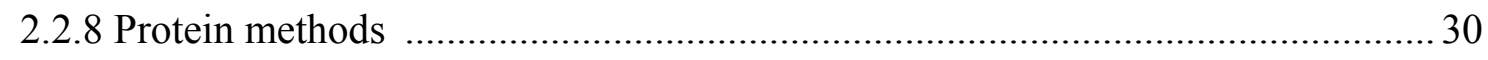

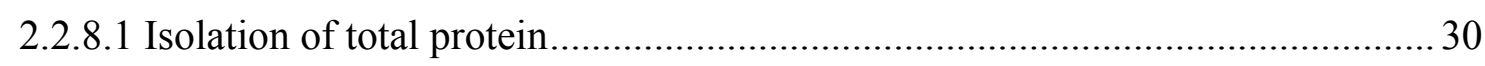




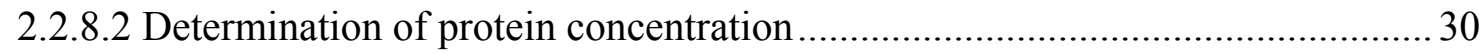

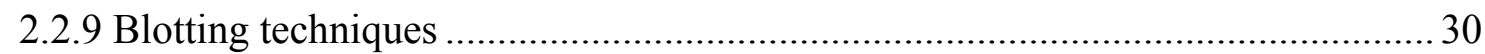

2.2.9.1 Southern blotting of DNA onto nitrocellulose filter ...................................... 30

2.2.9.2 Northern blotting of RNA onto nitrocellulose filter ...................................... 31

2.2.9.3 Western blotting of protein onto PVDF membrane.................................... 31

2.2.9.4 Incubation of protein-bound membranes with antibodies ............................... 32

2.2.10 "Random Prime" method for generation of ${ }^{32} \mathrm{P}$ labelled DNA......................... 32

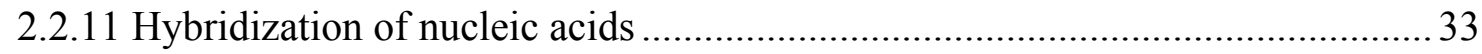

2.2.12 Non-radioactive dye terminator cycle sequencing......................................... 33

2.2.13 Transfection of NIH 3T3 cells with the Brunol1-EGFPC-1 and Brunol1

EGFPN-1 constructs ...................................................................... 34

2.2.14 Techniques for recovery and culture of preimplantation embryos ..................... 34

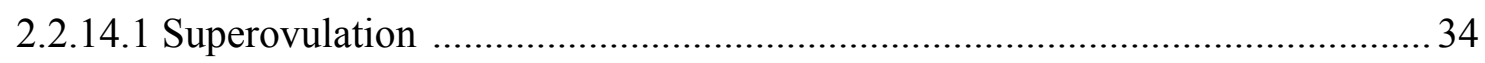

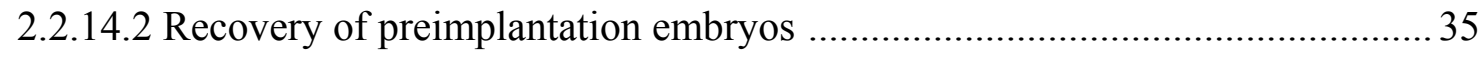

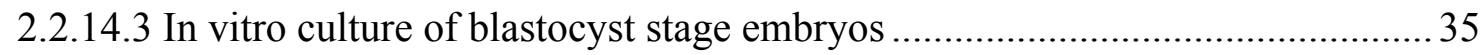

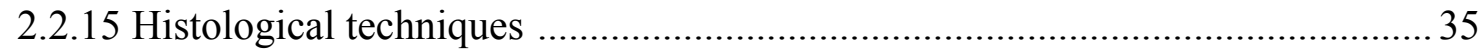

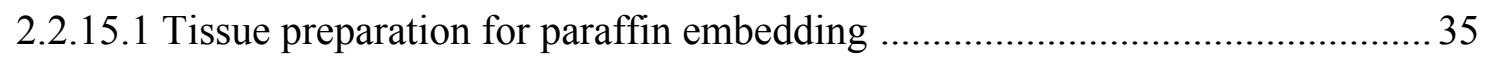

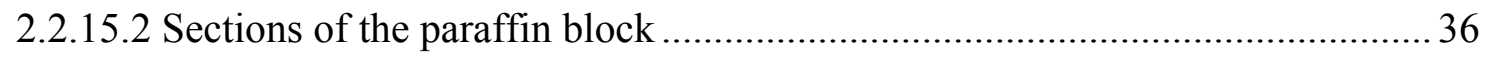

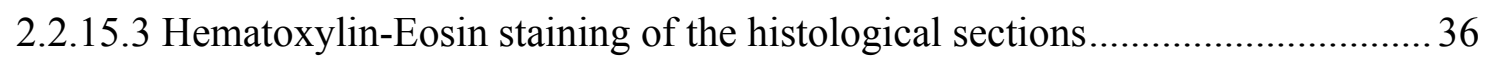

2.2.16 Techniques for production of targeted mutant mice ....................................... 36

2.2.16.1 Production of targeted embryonic stem cell clones ..................................... 37

2.2.16.1.1 Preparation of EMFI feeder layer.. ..................................................... 37

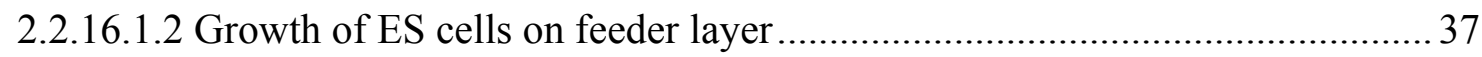

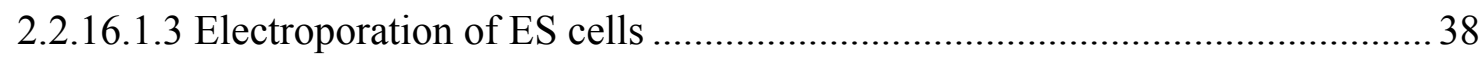

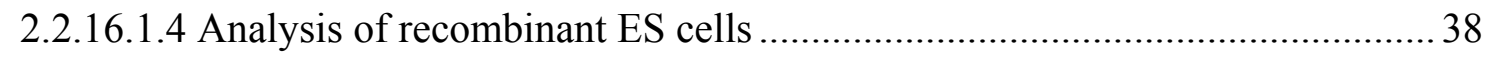

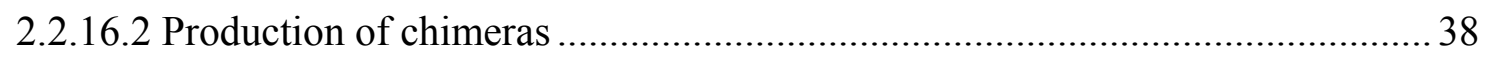

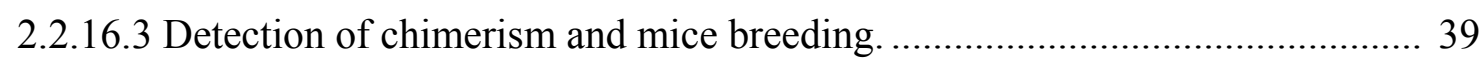

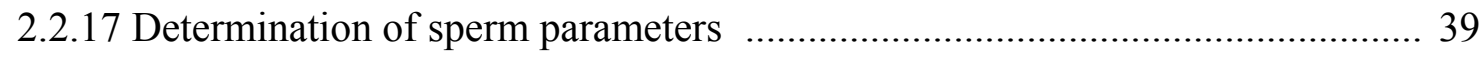

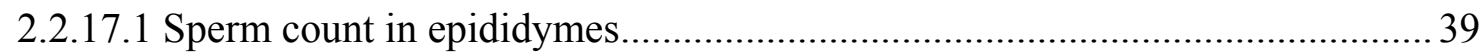

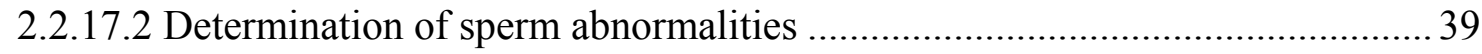

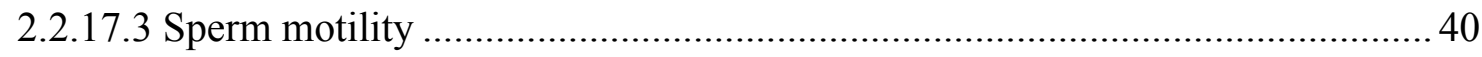

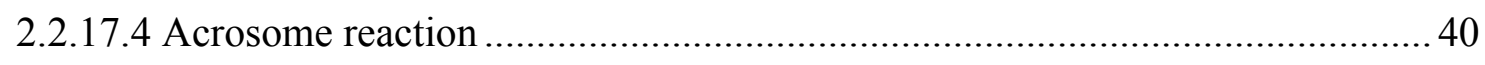

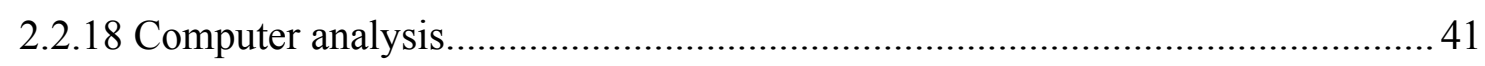


3. RESULTS

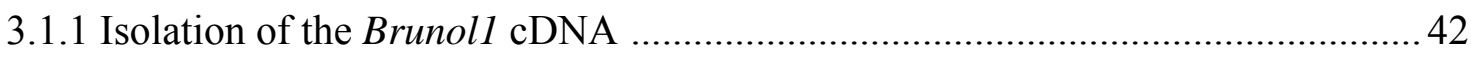

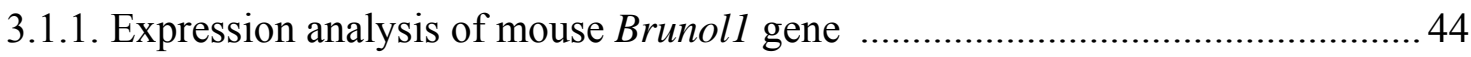

3.1.1.1 Analysis of Brunol1 during embryonic development .................................... 44

3.1.1.2 RT-PCR analysis of Brunol1 in adult mouse .................................................. 45

3.1.1.3 Northern Blot analysis of Brunol1 in adult mouse ........................................ 46

3.1.1.4 Localisation of Brunol1 protein in the cell .................................................... 47

3.1.2 Targeted inactivation of mouse Brunol1 gene .............................................. 48

3.1.2.1 Isolation and characterization of the cosmid clone with mouse genomic DNA 49

3.1.2.2 Construction of the Brunol1 knockout construct ........................................... 49

3.1.2.3 Subcloning of 5' wing of the Brunol1 knockout construct into the pGATA

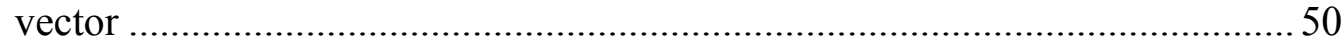

3.1.2.4 Subcloning of 3' wing of the Brunoll knockout construct into

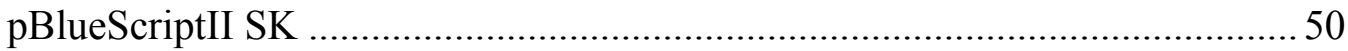

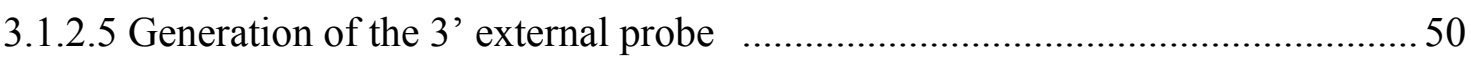

3.1.2.6 Electroporation of the ES cells and screening of ES cells for homologous

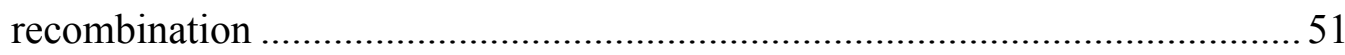

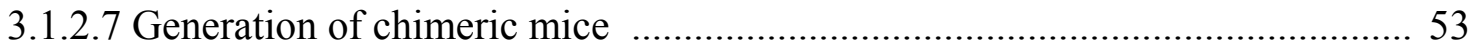

3.1.2.8 Generation and analysis of Brunol1 knock out mice ................................... 53

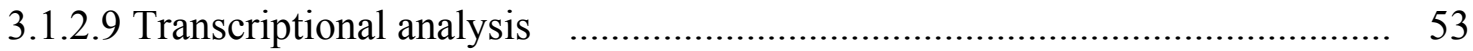

3.1.3 Phenotypic analysis of Brunol1 knockout mice .............................................. 54

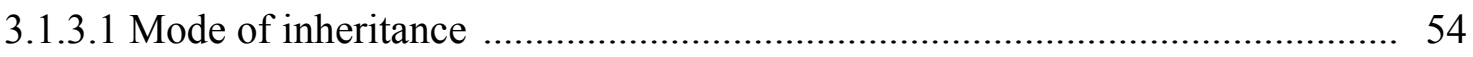

3.1.3.2 Analysing the fertility of Brunol1 deficient males ..................................... 56

3.1.3.3 Sperm count, acrosome reaction and analysis of sperm morphology of

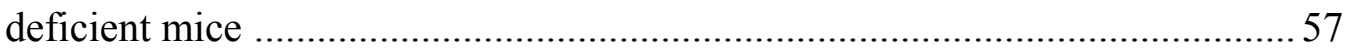

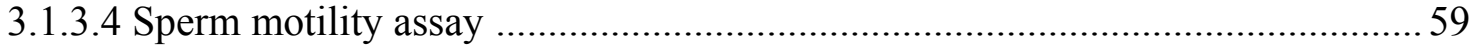

3.1.3.5 Histological analysis of Brunol1deficient males testes ..................................63

3.1.3.6 Expression analysis of Brunol6 by Northern blot in Brunol1 deficient mice

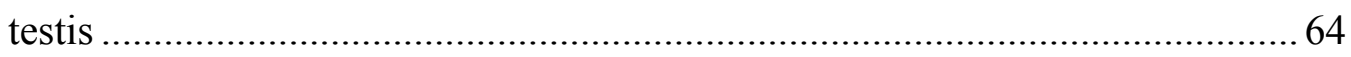

3.1.4 Histological analysis of brain of Brunol1 deficient mice $\quad$................................. 65

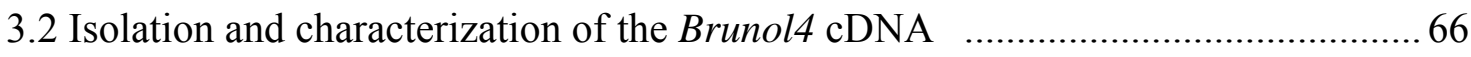

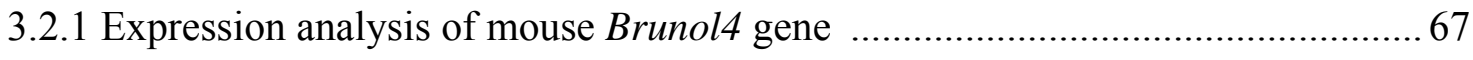

3. 2.1.1 RT PCR analysis of Brunol4 during development ........................................67 


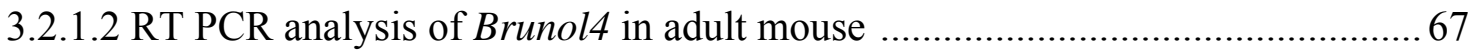

3.2.1.3 Northern Blot analysis of Brunol4 in adult mouse ....................................... 68

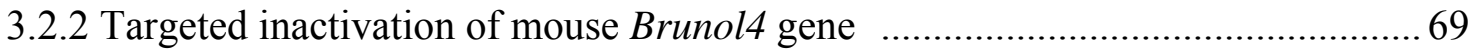

3.2.2.1 Generation of the Brunol4 knockout construct ........................................... 69

3.2.2.2 Subcloning of 5' wing of the Brunol4 knockout construct into the vector pBlueScriptII SK

3.2.2.3 Subcloning of 3' wing of the Brunol4 knockout construct into the pBlueScriptII SK

3.2.2.4 Generation of the 5' external probe

3.2.2.5 Electroporation of the ES cells and screening of ES cells for homologous recombination

3.2.2.6 Generation of chimeric mice

3.2.2.7 Generation and analysis of Brunol4 knock out mice 72

3.2.3 Determination of the stage of embryonic death of Brunol4 homozygous mice.. 73

3.2.4 Murine Brunol4 present in more than one copy ............................................. 77

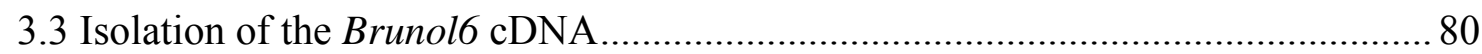

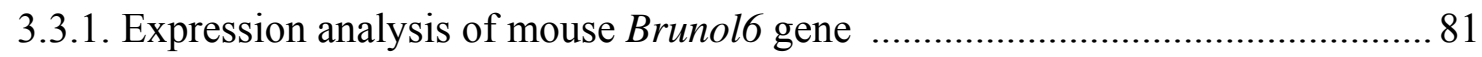

3.3.1.1. Expression analysis of Brunol6 during embryonic development .................... 81

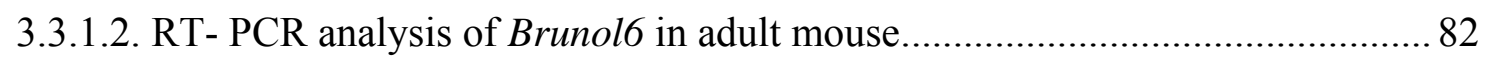

3.3.1.3 Northern Blot analysis of Brunol6 in adult mouse ......................................... 84

3.4 Study of the activation of the Brunol4 gene in preimplantation development .......85

3.4.1 Expression study of Brunol4 during embryonic development ........................... 85

3.4.2 Expression study of Brunol4 transcript of unfertilised oocytes .......................... 86

3.4.3 Study of the activation of Brunol4 gene at two-cell stage .................................. 87

3.4.4 Study of the activation of Brunol4 gene at four and eight-cell stage .................. 88

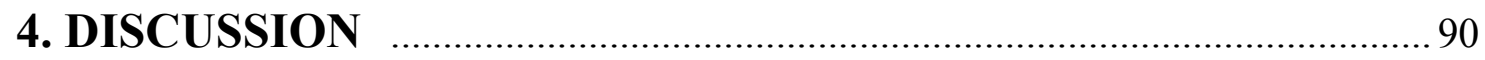

4.1 Evolutionary conservation of Elav/Bruno family …............................................. 90

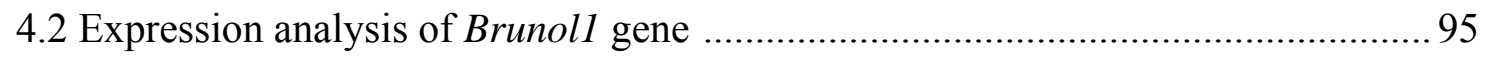

4.2.1 RT-PCR analysis of Brunol1 during embryonic development ........................... 95

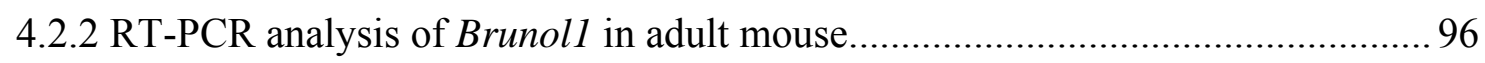

4.2.3 Expression analysis of Brunol1 in adult mouse by northern blot ....................... 97

4.2.4 Subcellular localization of Brunoll protein......................................................... 98 
4.3 Brunol1 deficient mice are fertile and undergo normal spermatogenesis ...............98

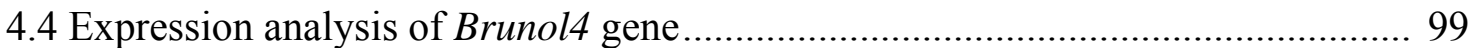

4.5 Functional analysis of Brunol4 gene by generation of Brunol4 deficient mice .... 102

4.5.1 Generation of Brunol4 knockout mice............................................................. 102

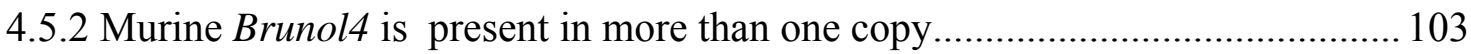

4.6 Activation of Brunol4 gene in preimplantation embryonic development ............. 104

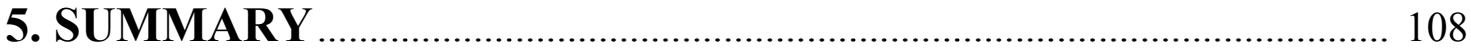

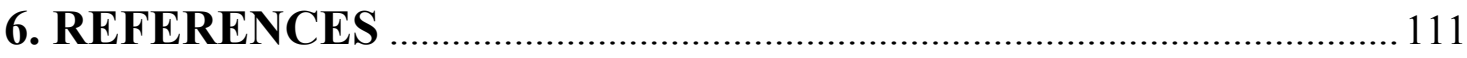

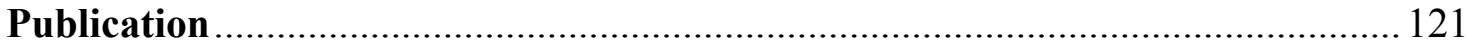

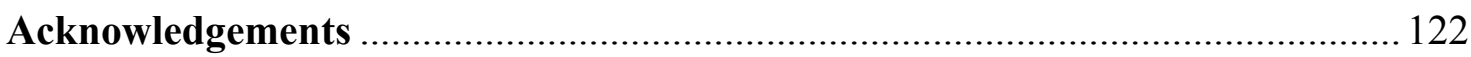

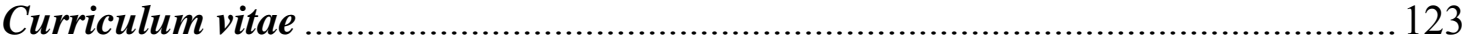


ABBREVIATIONS

ABI

AP

ATP

BCIP

bp

BSA

${ }^{\circ} \mathrm{C}$

CASA

cDNA

dATP

$\mathrm{dH}_{2} \mathrm{O}$

DAPI

dCTP

DMEM

DEPC

DNA

DNAse

dNTP

dpc

dT

DTT

EDTA

EGFP

ES

$\mathrm{EtBr}$

FCS

g

HBSS

HE
Applied Biosystem Instrument

Alkaline Phosphatase

Adenosinetriphosphate

1-bromo-3-chloropropane

base pair

Bovine Serum Albumin

Degree Celsius

Computer Assisted Semen Analysis

complementary DNA

desoxyriboadenosintriphosphate

distilled water

Diamidino-2-phenylindole dihydrochloride

Desoxyribocytosinetriphosphate

Dulbecco's Modified Eagle Medium

Diethylpyrocarbonate

Deoxyribonucleic acid

Deoxyribonuclease

deoxynucleotidetriphosphate

day post coitum

deoxythymidinate

Dithiothreitol

Ethylene Diamine Tetraacetic Acid

Enhanced Green Fluorescence Protein

Embryonic Stem

Ethidium Bromide

Fetal Calf Serum

gravity

Hanks' Balanced Salt Solution

Heterozygote 


\begin{tabular}{|c|c|}
\hline HEPES & N-(-hydroxymethyl)piperazin,N'-3-propanesulfoneacid \\
\hline $\operatorname{hr}(\mathrm{s})$ & hour(s) \\
\hline $\mathrm{HO}$ & Homozygote \\
\hline ICM & Inner Cell Mass \\
\hline ICSI & Intracytoplasmic Sperm Injection \\
\hline IPTG & Isopropyl- $\beta$-thiogalactopyranoside \\
\hline $\mathrm{kb}$ & kilobase \\
\hline Kda & Kilodalton \\
\hline mRNA & messenger Ribonucleic acid \\
\hline $\mathrm{mg}$ & milligram \\
\hline $\mathrm{ml}$ & millilitre \\
\hline$\mu 1$ & microlitre \\
\hline$\mu \mathrm{m}$ & micrometre \\
\hline $\min$ & minute \\
\hline $\mathrm{NaAc}$ & Sodium acetate \\
\hline NBT & Nitro-blue tetrazolium \\
\hline NCBI & National Center for Biotechnology Information \\
\hline Neo & Neomycin \\
\hline ng & nanogram \\
\hline $\mathrm{nm}$ & nanometer \\
\hline OD & Optimal Density \\
\hline ORF & Open Reading Frame \\
\hline
\end{tabular}

\section{Symbols of nucleic acids}

$\begin{array}{ll}\text { A } & \text { Adenosine } \\ \text { C } & \text { Cytidine } \\ \text { G } & \text { Guanosine } \\ T & \text { Thymidine } \\ \mathrm{U} & \text { Uridine }\end{array}$




\section{Symbols of amino acids}

\begin{tabular}{lll} 
A & Ala & Alanine \\
B & Asx & Asparagine or Aspartic acid \\
C & Cys & Cysteine \\
D & Asp & Aspartic acid \\
E & Glu & Glutamic acid \\
F & Phe & Phenylalanine \\
G & Gly & Glycine \\
H & His & Histidine \\
I & Ile & Isoleucine \\
K & Lys & Lysine \\
L & Leu & Leucine \\
M & Met & Methionine \\
N & Asn & Asparagine \\
P & Pro & Proline \\
Q & Gln & Glutamine \\
R & Arg & Arginine \\
S & Tyr & Serine \\
T & Thr & Threonine \\
V & Val & Valine \\
W & Trp & Tryptophan \\
Y & Tyrosine \\
\hline & Glutamine or Glutamic acid \\
\hline
\end{tabular}




\section{INTRODUCTION}

The post-transcriptional regulation of gene expression by RNA-binding proteins is an important element in controlling both normal cell functions and animal development. Proteins that contain RNA recognition motifs (RRMs) represent a large family with diverse functions in RNA metabolism (Burd and Dreyfuss, 1994). Many of these proteins have normal 'housekeeping' functions such as rRNA processing, translation initiation, constitutive RNA processing and RNA transport to the cytoplasm. Others are expressed in a tissue- or developmental specific manner, suggesting a role in regulating gene expression in specialized cells (Antic and Keene, 1997).

\subsection{Elav/Bruno/CELF RNA binding protein family}

Elav is the superfamily of RNA binding proteins; Bruno is a subfamily of the elav family. The members of the Bruno family have been predicted from database searches; They are named bruno-like genes due to their relation to the bruno sequence (Good et al., 2000). The founder member of Bruno-like family (BRUNOL) is the Drosophila protein, Bruno (Timchenko et al., 1996). Since then, other members have been identified mainly by sequence similarity. In fact, the founder member was cloned or identified in a number of laboratories which lead to profusion of names and the separate name systems. The other member of Bruno family, ETR (Embryonic lethal abnormal vision Type RNA-binding protein3) has $76 \%$ sequence identity with CUGBP1 (CUG repeats Binding Protein1) and was independently cloned during a screen for the genes expressed in apoptic neuroblastoma cells and from mouse liver using a probe to CUGBP1 and was named NAPRO and CUGBP2, respectively. The rapid increase in the amount of available sequence data allowed four other proteins with related sequences to be identified and the grouping of these seven gene products in families was proposed by Good et al. (2002) and Ladd et al. (2001). These authors suggested two different systems. Good's system is based on the similarity to the Drosophila protein, Bruno and the proteins are called Bruno-like (BRUNOL 1, 2 etc) whereas that of Ladd uses the similarity of the CUG-BP1 and ETR-3 proteins and the members are called CUG-BP1 and ETR-3 Like Factors (CELF). Neither system is complete as BRUNOL1 is not represented in the CELF family and similarly CELF3 is absent from BRUNOL system. The correspondence between these two systems and certain information on the expression pattern is given in Table1.0. 


\begin{tabular}{|c|c|c|c|c|c|c|c|}
\hline Species & & & UNOL/CEI & $F$ fam & member & & \\
\hline $\begin{array}{l}\text { Homo } \\
\text { sapiens }\end{array}$ & $\begin{array}{l}\text { BRUNOL1 } \\
\text { Brain }\end{array}$ & $\begin{array}{l}\text { CUG-BP1 } \\
\text { CELF1 }\end{array}$ & $\begin{array}{l}\text { CUG-BP2 } \\
\text { CELF2 } \\
\text { ETR-3 } \\
\text { BRUNOL3 } \\
\text { Human: heart, } \\
\text { skeletal muscle } \\
\text { and brain }\end{array}$ & $\begin{array}{l}\text { CELF3 } \\
\text { Brain }\end{array}$ & $\begin{array}{l}\text { CELF4 } \\
\text { BRUNOL4 } \\
\text { Many tissues }\end{array}$ & $\begin{array}{l}\text { CELF5 } \\
\text { BRUNOL5 } \\
\text { Brain }\end{array}$ & $\begin{array}{l}\text { CELF6 } \\
\text { BRUNOL6 } \\
\text { Many } \\
\text { tissues, } \\
\text { (Mainly, } \\
\text { kidney, } \\
\text { brain and } \\
\text { testis ) }\end{array}$ \\
\hline $\begin{array}{l}\text { Mus } \\
\text { musculus }\end{array}$ & $\begin{array}{l}\text { Brunol1 } \\
\text { CAGH4 } \\
\text { Etr-1 } \\
\text { Brain and } \\
\text { testis }\end{array}$ & $\begin{array}{l}\text { Brunol2 } \\
\text { Ubiquitous }\end{array}$ & $\begin{array}{l}\text { ETR-3 } \\
\text { ubiquitous } \\
\text { (Mainly brain } \\
\text { heart, lung, } \\
\text { skeletal muscle) }\end{array}$ & & $\begin{array}{l}\text { Brunol4 } \\
\text { Brain }\end{array}$ & $\begin{array}{l}\text { Brunol5 } \\
\text { Brain }\end{array}$ & $\begin{array}{l}\text { Brunol6 } \\
\text { Brain and } \\
\text { testis }\end{array}$ \\
\hline $\begin{array}{l}\text { Xenopus } \\
\text { laevis }\end{array}$ & $\begin{array}{l}\text { Etr-1 } \\
\text { BrunoL-1 } \\
\text { Nervous } \\
\text { system }\end{array}$ & $\begin{array}{l}\text { EDEN-BP } \\
\text { BrunoL-2 } \\
\text { Embryos }\end{array}$ & $\begin{array}{l}\text { Etr-3 } \\
\text { BrunoL-3 }\end{array}$ & & & & \\
\hline Rerio danio & $\begin{array}{l}\text { Etr-1 } \\
\text { Nervous } \\
\text { system } \\
\text { in embryos }\end{array}$ & $\begin{array}{l}\text { Brul } \\
\text { Vegetal pole } \\
\text { in oocytes } \\
\text { and early } \\
\text { embryos }\end{array}$ & $\begin{array}{l}\text { Etr-3 } \\
\text { Nervous system } \\
\text { in embryos }\end{array}$ & & & & \\
\hline
\end{tabular}

Table 1.0 Correspondence between the CELF/Bruno-like genes identified in vertebrates. The different names of the BRUNOL/ CELF family members cloned in vertebrates are given. The tissues in which the expression of each member has been observed is indicated.

\subsection{The modular domains of Elav/Bruno RNA binding protein family}

A model for the functional domains of ELAV/Bruno like RNA binding proteins is presented in Fig 1.0. All proteins within this family have the same domain structure: an amino terminal domain, two consecutive RRMs, a 50-70 amino acid tether or linker domain and a carboxyterminal third RRM (Burd and Dreyfuss, 1994). The most highly conserved sequences within the RRMs are the ribonucleoprotein 1 (RNP1 and RNP2) motifs that are signature sequences for the RRM and have been shown to specifically 
interact with RNA (Merrill et al., 1987). The bipartite structure of Bruno- like RNA binding proteins allows for two target RNAs to bind to the proteins, either in cis, allowing for interactions within the same RNA, or in trans, bringing two RNAs together. The binding of Bruno/ ELAV like RNA binding proteins to RNA could be accompanied by binding to other proteins to form a functional RNP complex. Protein interaction domains could be anywhere, including within the RRMs. Finally, this model proposes that ELAVlike proteins bind to specific target RNAs and regulate their expression by formation of a functional RNP complex.

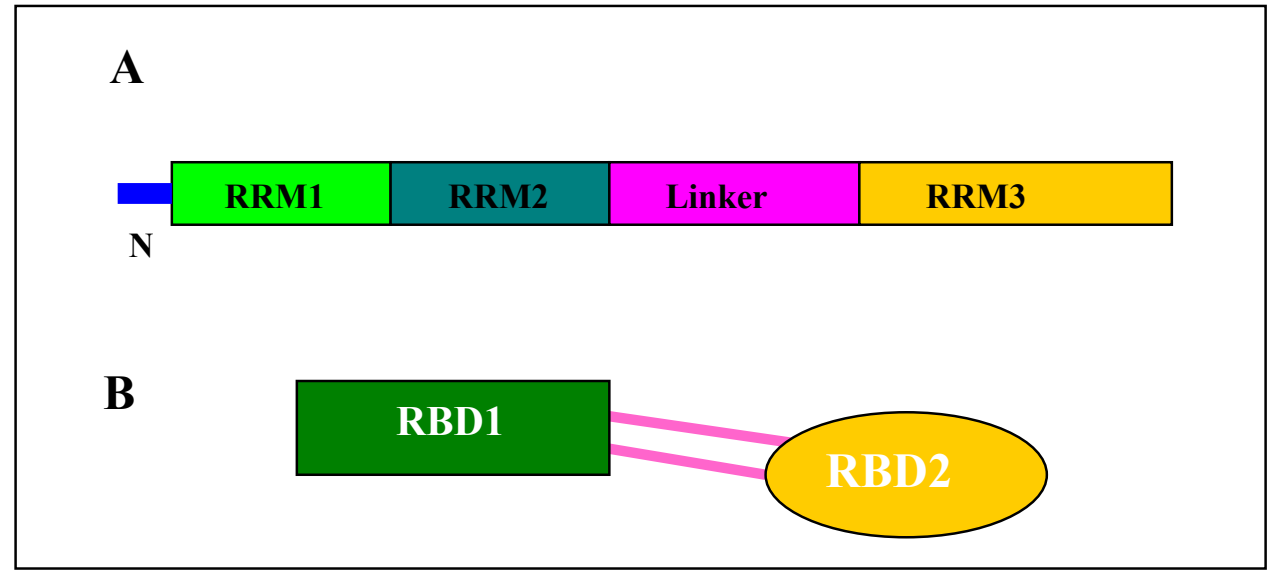

Figure 1.0. A model for the domain organization of a Bruno-like protein. (A) Linear representation of an ELAV-like protein is on top with the labeled boxes representing different domains. The box labeled $\mathrm{N}$ is the amino terminus while other boxes are labeled as described in the text. (B) The cartoon on the bottom is a proposed structure with two RNA-binding domains RBD separated by a linker region.

\subsection{Functional role of ELAV/Bruno like RNA binding proteins}

The importance of RNA binding proteins (RBPs) in development is underscored by the isolation of mutants with interesting developmental phenotypes where the defective gene encodes a RBP. In Drosophila melanogaster (Yao et al., 1993), Caenorhabditis elegans (Lundquist et al., 1996), mouse (Ebersole et al., 1996), and Arabidopsis thaliana (Macknight et al., 1997), mutants with defects in RBPs are defective in cell growth and differentiation.

An example of a RBP that regulates development is provided by the Bruno protein and its role as a translational repressor of oskar mRNA. In Drosophila, oskar is required for formation of germ cells and positioning of the posterior of the embryo (Lehmann and 
Nüsslein-Volhard, 1996). Both oskar mRNA and the encoded protein must be properly localized to the posterior pole of the oocyte for correct development (Ephrussi and Lehmann, 1992; Kim-Ha et al., 1995). Localized expression of Oskar protein is determined in part by translational silencing of the oskar mRNA outside of the posterior of the oocyte. This repression is mediated by cis-acting sequences in the 39-untranslated region (UTR) of oskar mRNA, called Bruno response elements (BREs) and a corresponding trans-acting factor, the Bruno protein. Deletion of these BREs results in inappropriate translation of oskar mRNA in the anterior end of the oocyte leading to embryos with two posterior poles. The Bruno protein is a RRM-containing protein present in oocytes. Extracts prepared from Drosophila ovaries recapitulate this Bruno-dependent translational repression of oskar mRNA in vitro (Lie and Macdonald,1999). By regulating the localized expression of oskar, Bruno has a key role in germ cell formation and early embryogenesis.

Members of the Elav family play roles in regulating differentiation because overexpression of different family members enhances the differentiation of 3T3-L1 cells into adipocytes (Jain et al., 1997), the teratocarcinoma cell line N-Tera2 into neurons (Antic and Keene, 1998; Antic et al., 1999), chicken neural crest stem cells into neurons (Wakamatsu and Weston, 1997) and the PC12 pheochromocytoma cells into neurons (Kasashima et al., 1999). In embryos, overexpression of Elav-like proteins results in altered neural differentiation in both frogs (Perron et al., 1999) and mice (Akamatsu et al., 1999). Thus, the Elav family has diverse roles in regulating development through several different mechanisms.

The Xenopus laevis Etr-1 gene was previously identified as a marker of the developing nervous system and is distantly related to the elav gene (Knecht et al., 1995). Subsequently, the Etr-1 protein was shown to be related to the Drosophila Bruno protein (Webster et al., 1997). Good et al. (2000) describe a family of human genes related to both Etr-1 and Bruno. The corresponding proteins have three RRMs and share a domain structure with the Elav family of proteins. The authors characterized in detail two members of this family, the BRUNOL2 gene, which is ubiquitously expressed, and the BRUNOL3 gene, which is expressed preferentially in muscle, heart, and the nervous system.

The BRUNOL2 and BRUNOL3 proteins bind to the same RNA sequence as the Drosophila Bruno protein, demonstrating a conservation of both protein sequence and RNA binding specificity. This binding occurs through the first two consecutive RRMs. The BRUNOL2 protein is identical to the CUGBP1, a RBP that binds to CUG repeats and is 
implicated in the etiology of the triplet repeat expansion disease myotonic dystrophy (Timchenko et al., 1996). Thus, members of this gene family may be involved in human disease as well as in differentiation of specific cell types.

\subsection{Isolation and characterisation of murine Brunol1 and Brunol4 gene, members of Elav/Bruno family}

The isolation of the genes, which play a role in human diseases, is of great importance for understanding and elucidating the molecular pathway that mediates progression in disease. Identifying the gene responsible for a human disease and elucidating its function not only help to determine the pathogenesis of the disease but also offer a possible therapy. Until now, there is a row of well-known genes like SCA7 (David et al., 1997), SCA2 (Sanpei et al.,1996) or Huntington (The Huntington 's disease Collaborative Research Group 1992), which play a role in the emergence of neurodegenerative diseases. A common characteristic of these diseases is the expansion of short tandem repeats of three (CAG or CTG) or five (ATTCT for SCA10) nucleotides (Orr et al., 1993; Nakamura et al., 2001). However, the genetic loci for at least $20 \%$ of familial autosomal dominant cerebellar ataxia (ADCSA) have yet to be identified, implying the presence of other unidentified responsible genes (Takano et al., 1998; Devos et al., 2001; Soong et al., 2001)

Thus, to identify a new candidate gene for neurodegenerative diseases, brain cDNA libraries of human and mouse were screened with 63 CAG repeats containing cDNA probes. The complete ORF of human and mouse Brunol1 consisting of 16 CAG repeats was isolated (Wilhelm et al 2001). When the cDNA and deduced amino acid sequences of Brunol1 were compared with the Genebank NCBI /EMBL and EST database, Brunol1 was shown to encode a novel protein belonging to the Elav/Bruno family. Further, Wilhelm et al. (2001) studied the patients, whose clinical and genetic findings indicated the absence of extended CAG repeats in the genetically characterized known genes responsible for neurodegenerative diseases. Then they examined, whether the Brunol1 cDNA of these patients have the variation in $\mathrm{CAG}$ repeats but none of them was found to have extended CAG repeats in Brunol1 cDNA.

Meins et al. (2002) had screened adult mouse brain library with a probe generated from conserved parts of mouse Brunol1 cDNA sequence to identify other novel members of the elav/bruno family expressed in mouse neural tissues. Analysis of the positive clone DKFZp598E0330Q2 revealed major parts of the cDNA sequence of a novel elav-type 
related gene Brunol4, which proves to be the murine homologue to human BRUNOL4. A sequence was predicted from database searches (Good et al., 2000). To further identify a new member of Bruno family we have searched the mouse genome database for proteins, which have homology with Bruno family. A previously uncharacterized gene Brunol6 was identified.

\subsection{Aim of the study}

The aim of this study was the expression and functional analysis of Brunol1and Brunol4 genes. Scientific approaches undertaken in this study are as follows:

1. An expression study of Brunol1, Brunol4 and Brunol6 gene by RT-PCR and Northern blot.

2. Subcellular localisation of Brunol1 protein in the cell.

3. Functional analysis of Brunol1 and Brunol4 genes in knockout mouse models.

4. Study of the embryonic genome activation of Brunol4 gene. 


\section{MATERIALS AND METHODS}

\subsection{Materials}

\subsubsection{Chemicals}

Acrylamide/Bisacrylamide

Roth, Karlsruhe

Acetic acid

Merck, Darmstadt

Agar

Roth, Karlsruhe

Agarose

Invitrogen, Karlsruhe

Ammonium acetate

Fluka, Neu Ulm

Ampicillin

Sigma, Deisenhofen

Ampuwa

Fresenius, Bad Homburg

Bacto-tryptone

Roth, Karlsruhe

Bacto-Yeast-Extract

Roth, Karlsruhe

BCIP

Applichem, Darmstadt

Blocking powder

Roth, Karlsruhe

Boric acid

Scharlau Chemie, Barcelona

BSA

Biomol, Hamburg

Cell culture media

Invitrogen, Karlsruhe

Clonfectin

BD Clontech, Palo Alto

Coomasie G-250

Sigma, Deisenhofen

Chloroform

Merck, Darmstadt

Crystal violet

Sigma, Deisenhofen

Vectashield (DAPI)

Vector, Burlingame

Diethyl pyrocarbonate (DEPC)

Sigma, Deisenhofen

Dulbecco's Modified Eagle Medium

(DMEM)

Merck, Darmstadt

Dimethyl sulfoxid (DMSO)

Sigma, Deisenhofen

Dithiothreitol

Invitrogen, Karlsruhe

DNA Markers

Invitrogen, Karlsruhe

dNTPs (100 mM)

Dye Terminator Mix

Invitrogen, Karlsruhe

Applied Biosystems

EDTA

Sigma, Deisenhofen

Ethanol

Baker, Deventer, NL

Ethidium bromide

Roth, Karlsruhe 
Ficoll 400

FCS

Formaldehyde

Formamide

Glutaraldehyde

Glycerol

Glycine

HBSS medium

Horse serum

$\mathrm{HCl}$

$\mathrm{H}_{2} \mathrm{O}_{2}$

HEPES

Ionophore A23187

IPTG

Isopropanol

IVF Media

$1 \mathrm{~kb}$ DNA Ladder

0.24-9.5 RNA Ladder

$\mathrm{KCl}$

M16 medium

Methanol

$\mathrm{MgCl}_{2}$

MOPS

$\beta$-Mercaptoethanol

Mineral oil

$\mathrm{Na}$ azide

$\mathrm{Na}$ acetate

$\mathrm{Na}$ citrate

$\mathrm{Na}$ deoxycholate

$\mathrm{NaCl}$

$\mathrm{Na}_{2} \mathrm{HPO}_{4}$

$\mathrm{NaH}_{2} \mathrm{PO}_{4}$

$\mathrm{NaN}_{3}$
Applichem, Darmstadt

Invitrogen, Karlsruhe

Merck, Darmstadt

Sigma, Deisenhofen

Serva, Heidelberg

Invitrogen, Karlsruhe

Biomol, Hamburg

Sigma, Deisenhofen

Sigma, Deisenhofen

Roth, Karlsruhe

Merck, Darmstadt

Merck, Darmstadt

Calbiochem, Bad Soden

Biomol, Hamburg

Merck, Darmstadt

Medicult, Berlin

Gibco BRL, Karlsruhe

Gibco BRL, Karlsruhe

Merck, Darmstadt

Sigma, Deisenhofen

Merck, Darmstadt

Merck, Darmstadt

Applichem, Darmstadt

Serva, Heidelberg

Sigma, Deisenhofen

Sigma, Deisenhofen

Merck, Darmstadt

Merck, Darmstadt

Merck, Darmstadt

Merck, Darmstadt

Merck, Darmstadt

Merck, Darmstadt

Merck, Darmstadt 
$\mathrm{NaOH}$

NBT

Neomycin (G-418)

NuPAGE LDS sample buffer (4x)

NuPAGE MOPS SDS running buffer

Orange $\mathrm{G}$

OPTI-MEM I

Penicillin/Streptomycin

PBS

Phosphoric acid

Picric acid

Phenol

Proteinase K

Protein marker

Radioactive substances:

$\left[\gamma^{32} \mathrm{P}\right]$-ATP $\left[\alpha^{32} \mathrm{P}\right]-\mathrm{dCTP}$

Rediprime $^{\mathrm{TM}}$.II

RNase Inhibitor

RNA length standard

RNA reagent

RNAse away

Saccharose

Salmon sperm DNA

SDS

S.O.C Medium

Triton X-100

Tris

Tween-20

X-Gal

Xylol
Merck, Darmstadt

Applichem, Darmstadt

PAN, Aidenbach

Invitrogen, Karlsruhe

Invitrogen, Karlsruhe

Sigma, Deisenhofen

Invitrogen, Karlsruhe

PAN, Aidenbach

Invitrogen, Karlsruhe

Merck, Darmstadt

Fluka, Neu Ulm

Biomol, Hamburg

Applichem, Darmstadt

Invitrogen, Karlsruhe

Amersham, Braunschweig

Amersham, Freiburg

Boehringer, Mannheim

Invitrogen, Eggenstein

Biomol, Hamburg

Biomol, Hamburg

Roth, Karlsruhe

Sigma, Deisenhofen

Serva, Heidelberg

Invitrogen, Karlsruhe

Serva, Heidelberg

Sigma, Deisenhofen

Promega, Mannheim

Biomol, Hamburg

Merck, Darmstadt

All those chemicals, which are not mentioned above, were ordered from Merck, Darmstadt or Roth, Karlsruhe 


\subsubsection{Solutions, buffers and media}

\subsubsection{Agarose gel electrophoresis}

5X TBE buffer

$450 \mathrm{mM}$ Trisbase

$450 \mathrm{mM}$ Boric acid

20 mM EDTA (pH 8.0)

Glycerol loading buffer-I

$10 \mathrm{mM}$ Tris/ $\mathrm{HCl}(\mathrm{pH} 7.5)$

10 mM EDTA (pH 8.0)

$0.025 \%$ Orange G

$30 \%$ Glycerol

\subsubsection{SDS-PAGE}

40\% Acrylamide stock solution

Acrylamide $29.2 \%(\mathrm{w} / \mathrm{w})$

Bis-acrylamide $0.8 \%(\mathrm{w} / \mathrm{w})$

$10 \%$ Ammonium persulfate solution in $\mathrm{H}_{2} \mathrm{O}$

NuPAGE gel SDS sample buffer (4x) 10\% Glycerol

$62.5 \mathrm{mM}$ Tris $/ \mathrm{HCl}(\mathrm{pH} 6.8)$

$2 \%$ SDS

$0.01 \mathrm{mg} / \mathrm{ml} \mathrm{BPB}$

Running buffer (5x)

$25 \mathrm{mM}$ Tris/ $\mathrm{HCl}(\mathrm{pH} 8.3)$

192 mM Glycine

$0.1 \%$ SDS

Stacking gel buffer (4x)

0.5 M Tris/HCl (pH 6.8)

$0.4 \%$ SDS

Separating gel buffer $(4 \mathrm{x})$

1.5 M Tris/ $\mathrm{HCl}(\mathrm{pH} 8.3)$

$0.4 \%$ SDS 


\subsubsection{Frequently used buffers and solutions}

AP buffer

BCIP-Solution

Blocking solution (immunostaining)

Bouin's solution

Carrier DNA

Denaturation solution

Depurination solution

E-buffer (10x)

Elution buffer

Ligation buffer (10x)
100 mM Tris- $\mathrm{HCl}(\mathrm{pH} 9.5)$

$100 \mathrm{mM} \mathrm{NaCl}$

$50 \mathrm{mM} \mathrm{MgCl}_{2}$

$50 \mathrm{mg} / \mathrm{ml} \mathrm{BCIP}$

$70 \%$ Dimethyl formamide

$60 \mu 1$ of horse serum,

$150 \mu 1$ of $10 \%$ Triton X-100

$2790 \mu \mathrm{l}$ PBS

15 volume of picric acid (in $\mathrm{H}_{2} \mathrm{O}$ )

5 volume $37 \%$ formaldehyde

1 volume acetic acid

sonicated salmon sperm DNA, $5 \mathrm{mg} / \mathrm{ml}$

$1.5 \mathrm{M} \mathrm{NaCl}$

$0.5 \mathrm{M} \mathrm{NaOH}$

$0.25 \mathrm{M} \mathrm{HCl}$

$300 \mathrm{mM} \mathrm{NaH}_{2} \cdot \mathrm{PO}_{4}$

$50 \mathrm{mM}$ EDTA

\section{$1.5 \mathrm{M} \mathrm{NaCl}$}

$20 \mathrm{mM}$ Tris/ $\mathrm{HCl}(\mathrm{pH} 7.5)$

$1 \mathrm{mM}$ EDTA

$600 \mathrm{mM}$ Tris/HCl (pH 7.5)

$80 \mathrm{mM} \mathrm{MgCl}_{2}$. 
$100 \mathrm{mM}$ DTT

Lysis-buffer I

$100 \mathrm{mM}$ Tris/ $\mathrm{HCl}(\mathrm{pH} 8.0)$

$100 \mathrm{mM} \mathrm{NaCl}$

100 mM EDTA

$0.5 \%$ SDS

Lysis-buffer II

$100 \mathrm{mM}$ Tris/HCl (pH 8.0)

$5 \mathrm{mM}$ EDTA

$200 \mathrm{mM} \mathrm{NaCl}$

$0.2 \%$ SDS

$100 \mu \mathrm{g} / \mathrm{ml}$ proteinase $\mathrm{K}$

10 X MOPS buffer

$41.8 \mathrm{~g}$ MOPS

$16.6 \mathrm{ml} 3 \mathrm{M}$ Sodium acetate

$20 \mathrm{ml} 0.5 \mathrm{M}$ EDTA

in 1 liter of DEPC Water

adjust $\mathrm{pH}$ to 6.75

NBT- Solution

$75 \mathrm{mg} / \mathrm{ml} \mathrm{NBT}$

70\% Dimethyl formamide

Neutralisation solution

$1.5 \mathrm{M} \mathrm{NaCl}$

$1 \mathrm{M}$ Tris $/ \mathrm{HCl}(\mathrm{pH} 7.0)$

PBS buffer

$130 \mathrm{mM} \mathrm{NaCl}$

$7 \mathrm{mM} \mathrm{Na}_{2} \mathrm{HPO}_{4}$

$4 \mathrm{mM} \mathrm{NaH}_{2} \cdot \mathrm{HPO}_{4}$

Protein lysis buffer

$150 \mathrm{mM} \mathrm{NaCl}$

10 mM EDTA

$50 \mathrm{mM}$ Tris/HCl pH7.6

$1 \%$ Triton $\mathrm{X}-100$ 
$1 \%$ sodium deoxycholate

Semidry transfer buffer $(1 \mathrm{x})$

$25 \mathrm{mM}$ Tris $\mathrm{pH} 8.3$

150 mM Glycin

$10 \%$ Methanol

$\operatorname{SSC}(20 x)$

$3 \mathrm{M} \mathrm{NaCl}$

$0.3 \mathrm{M} \mathrm{Na}_{3}$ citrate ( $\left.\mathrm{pH} 7.0\right)$

Stop-Mix

15\% Ficoll 400

200 mM EDTA

$0.1 \%$ Orange G

TE-buffer

$10 \mathrm{mM}$ Tris/ $\mathrm{HCl}$ (pH 8.0)

1 mM EDTA

Washing solution I

2x SSC

$0.1 \%$ SDS

Washing solution II

$0.2 \mathrm{xSC}$

\subsubsection{Laboratory materials}

The laboratory materials, which are not listed here, were bought from Schütt and Krannich (Göttingen).

Cell culture flasks

Dialysis hoses

Disposable filter Minisart

Filter paper 0858

Hybond - C

Hybond - N

Microcentrifuge tubes

Petri dishes
Greiner, Nürtingen

Serva, Heidelberg

NMI Sartorius, Göttingen

Schleicher and Schüll, Dassel

Amersham, Braunschweig

Amersham, Braunschweig

Eppendorf, Hamburg

Greiner, Nürtingen 
Pipette tips

Roti-plast paraffin

Superfrost slides

Culture slides

Whatman blotting paper

(GB 002, GB 003 and GB 004)

$\mathrm{X}$-ray films
Eppendorf, Hamburg

Roth, Karlsruhe

Menzel, Gläser

Lab-Tek/Nalge, Nunc, IL, USA

Schleicher and Schüll, Dassel

Amersham, Braunschweig

\subsubsection{Sterilisation of solutions and equipments}

All solutions that are not heat sensitive were sterilised at $121^{\circ} \mathrm{C}, 10^{5} \mathrm{~Pa}$ for $60 \mathrm{~min}$ in an autoclave (Webeco, Bad Schwartau). Heat sensitive solutions were filtered through a disposable sterile filter ( 0.2 to $0.45 \mu \mathrm{m}$ pore size). Plastic wares were autoclaved as above. Glassware were sterilised overnight in an oven at $220^{\circ} \mathrm{C}$.

\subsubsection{Media, antibiotics and agar-plates}

\subsubsection{Media for bacteria}

LB Medium (pH 7.5):

$$
\begin{aligned}
& 1 \% \text { Bacto-tryptone } \\
& 0.5 \% \text { Yeast extract } \\
& 1 \% \mathrm{NaCl}
\end{aligned}
$$

LB-Agar:

$$
\begin{aligned}
& 1 \% \text { Bacto-tryptone } \\
& 0.5 \% \text { Yeast extract } \\
& 1 \% \mathrm{NaCl} \\
& 1.5 \% \text { Agar }
\end{aligned}
$$

The LB medium was prepared with distilled water, autoclaved and stored at $4{ }^{\circ} \mathrm{C}$.

\subsubsection{Mammalian cell culture media}

M2 and M16 media were purchased from Sigma, (Deisenhofen) and were used for washing and cultivation of mouse preimplantation embryos.

Dulbecco's MEM (DMEM) medium containing:

$10 \%$ fetal calf serum (FCS)

2 mM L-Glutamine

$1 \%$ of penicillin $(6 \mathrm{mg} / \mathrm{ml}) / \mathrm{streptomycin}(5 \mathrm{mg} / \mathrm{ml})$ solution 
This medium was used to culture the NIH $3 \mathrm{~T} 3$ cells. For long time storage of the cells in liquid nitrogen, the following freezing medium was used:

$$
\begin{aligned}
& 90 \% \text { culture media } \\
& 10 \% \text { DMSO }
\end{aligned}
$$

\subsubsection{Antibiotics}

Stock solutions were prepared for the antibiotics. The stock solutions were then filtered through sterile disposable filters and stored at $-20^{\circ} \mathrm{C}$. When antibiotics were needed, in each case it was added after the autoclaved medium has cooled down to a temperature lower than $55^{\circ} \mathrm{C}$.

\section{Antibiotic}

Ampicillin

Kanamycin

G 418

Gancyclovir

Mitomycin C

\section{Master solution Solvent}

$50 \mathrm{mg} / \mathrm{ml}$

$25 \mathrm{mg} / \mathrm{ml}$

$40 \mathrm{mg} / \mathrm{ml}$

$100 \mathrm{mM}$

$1 \mathrm{mg} / \mathrm{ml}$
$\mathrm{H}_{2} \mathrm{O}$

$\mathrm{H}_{2} \mathrm{O}$

PBS

PBS

PBS

\section{Final concentration}

$50 \mu \mathrm{g} / \mathrm{ml}$

$50 \mu \mathrm{g} / \mathrm{ml}$

$400 \mu \mathrm{g} / \mathrm{ml}$

$2 \mu \mathrm{M}$

$10 \mu \mathrm{g} / \mathrm{ml}$

\subsubsection{IPTG / X-Gal plate}

LB-agar with $50 \mu \mathrm{g} / \mathrm{ml}$ ampicillin, $100 \mu \mathrm{M}$ IPTG and $0.4 \%$ X-Gal was poured into Petri dishes. The dishes were stored at $4{ }^{\circ} \mathrm{C}$.

\subsubsection{Bacterial strains}
E. coli DH5 $\alpha$
Invitrogen
E. coli BL21 (DE3)
Novagen

\subsubsection{Plasmids}

pTK-Neo

pPNT-M1
Prof. N. Brose, MPI für Experimentelle Medizin, Göttingen

Prof. R. Mulligan, Children's Hospital, Boston, USA; modified by Prof $H$. Hahn, Institut für 


$\begin{array}{ll}\text { pZERO-2 } & \text { Invitrogen } \\ \text { pBluescript SK }(+/-) & \text { Stratagene, Amsterdam } \\ \text { pBluescript KS }(+/-) & \text { Stratagene, Amsterdam } \\ \text { pGEM-T Easy } & \text { Promega, Mannheim } \\ \text { pEGFP 1 } & \text { Clontech, Palo Alto } \\ \text { pEGFP-N1 } & \text { Clontech, Palo Alto } \\ \text { pET 41a+ } & \text { Novagen }\end{array}$

\subsubsection{Synthetic oligonucleotide primers}

The synthetic oligonucleotide primers used in this study were obtained either from Eurogentec (Köln) or Roth (Karlsruhe) and dissolved in water to a final concentration of $100 \mathrm{pmol} / \mu \mathrm{l}$.

\begin{tabular}{|l|l|}
\hline Bru-4 Geno-F & 5'GAGAGCCCAGAGCAGAGCAAGGTGTAGGAA3' \\
Bru-4 Del-R & 5'TGAGAGGGAAAGGTGCTCTCACCTTTGTG3' \\
GFP-1405-R & 5'TGTGGTATGGCTGATTATGATCTAGAGTCG3' \\
Bru-4 Geno-F3 & 5'AAGATGGCCACGTTAGCAAACGGA3' \\
Bru-4 Geno-F4 & 5'CTGACAACGCGAGCCTCAGTACCAA3' \\
Bru-4 Del-R-3 & 5'TGAGAGGGAAAGGTGCTCTCACC3' \\
Bru-4 Del-R-4 & 5'GTGAACCTGTCCTTCAGAACCGTA3' \\
GFP-916-R & 5'AGTCGTGCTGCTTCATGTGGTC3', \\
GFP-936-R & 5'AGCCTTCGGGCATGGCGGACTTGAA3' \\
Bru4-Ext-Probe-F & 5'AATACCCTGGCATCCTGCTTCGCAA3', \\
Bru4-Ext-Probe-R & 5'GGCCACAATTATTCATCCAC 3' \\
Bru4-Ntern-Probe-F & 5'TTTATAAATGAGAACTGTTGGACGAC3', \\
Bru4-Ntern Probe-R & 5'CCATTCCACCTCTAATTGACAGAG3' \\
Bru-1Geno-F & 5'TGGCTGTTGAGCTCACTCCTCTCCAGCAA3' \\
Bru-1 Del-R & 5'TGTTCAGGTCCATCCCCCTCATTAACAGTC3' \\
PGK-352-R & 5'GCCAGAAAGCGAAGGAGCAAAGCT3' \\
Bru1-Ext-Probe-F & 5'GTGTTTCATGGGCCTGTCTC3' \\
Bru1-Ext-Probe-R & 5'CCTGACCCCCAGAATATGTG3 \\
Bru4-cDNA-F & 5'ATGAAGGACCACGATGCCATCAAGCT 3', \\
\hline
\end{tabular}




\begin{tabular}{|l|l|}
\hline Bru4-cDNA-R & 5'TCAGTACGGGCGATTGGCGTCT3' \\
Bru1-Notrn-Probe-F & 5'CTTCAGGTCTGGAGATACCAGAGG3' \\
Bru1- Notrn Probe-R & 5'TGAGAGCCCGGGGTTTGGAGTTC3' \\
Bru-1GFP-F & 5'CAAGCTTCTATGAAGGAGCCAGATGCCAT3' \\
Bru-1GFP-R & 5'TGGATCCCCACCGTAGGGCCTGTTTGCATCCTT3' \\
Bru1-cDNA-F & 5'AATGAAGGAGCCAGATGCCATCAAGCTG3' \\
Bru1-cDNA-R & 5'GGACCATGAAGCAGCTCTTGCCCCAGAGTC3' \\
Bru1-CAG-F & 5' TC5'CACAAAGCCAAAACATTTGC3' \\
Bru1-CAG-R & ATG5'ATACCAGAGGAAGGGGCACTTCA3' \\
Bru1-3'UTR-F & GCTTGTGATGCTCTC3' \\
Bru1-3'UTR-R & 5'GGAGATCTCCTACCTCTAGCT3', \\
pET41-R & 5'ATGCTAGTTATTGCTCAGCGG3' \\
T7: & 5'TAA TAC GAC TCA CTA TAG GG 3' \\
T3: & 5'ATT AAC CCT TCA CTA AAG 3' \\
SP6 & 5'AGG TGA CAC TAT AGA ATA C 3' \\
&
\end{tabular}

\subsection{9 cDNA probes}

\begin{tabular}{|l|l|}
\hline$\beta$-actin cDNA & Clontech \\
Neo probe & Generated in present study \\
GFP probe & Generated in present study \\
Brunol4 3' cDNA probe & Generated in present study \\
Brunol4 external probe & Generated in present study \\
Brunol1 3' cDNA probe & Generated in present study \\
Brunol1 external probe & Generated in present study \\
\hline
\end{tabular}




\subsubsection{Eukaryotic cell lines}

RI mouse embryonic stem cell line

Dr. A. Nagi, Toronto, Canada

NIH 3 T3

S.A. Aaronson, Bethesda, U.S.A.

\subsubsection{Mouse strains}

Mouse strains C57BL/6J, 129X1/SvJ, C3H/J and DBA/2J were initially ordered from Charles River Laboratories, Wilmington, USA, and further bred in animal facility of Institute of Human Genetics, Göttingen.

\subsubsection{Enzymes}

Alkaline phosphatase

New England Biolabs,

Frankfurt am Main

Platinum Taq polymerase

Invitrogen, Karlsruhe

Proteinase K

Sigma, Deisenhofen

Restriction enzymes (with supplied buffers)

Invitrogen, Karlsruhe,

RNase A

Invitrogen, Karlsruhe

RNase H

Invitrogen, Karlsruhe

RNase inhibitors

Invitrogen, Karlsruhe

Superscript-II

Invitrogen, Karlsruhe

Taq Polymerase

Invitrogen, Karlsruhe

T4 DNA ligase

Promega, Mannheim

T4 RNA ligase

Invitrogen, Karlsruhe

Trypsin

Invitrogen, Karlsruhe

\subsubsection{Kits}

Dye Terminator Cycle Sequencing-Kit

Applied Biosystem

DYEnamic ET-Terminator mix

Amersham Pharmacia

Endo Free Plasmid Maxi Kit

Qiagen, Hilden

Lipofectamine 2000

Invitrogen, Karlsruhe

Megaprime DNA Labelling Kit

Amersham Pharmacia,

Maxi Plasmid Kit

Qiagen, Hilden

Mega Plasmid Kit

Qiagen, Hilden

Mini Plasmid Kit

Qiagen, Hilden 
QIAquick Gel Extraction Kit

Rediprime $^{\mathrm{TM}}$ II Random Prime Labeling System

RNeasy Minikit

\subsubsection{Instruments}

ABI PRISM 377 DNA Sequencer

ABI 3100 Genetic Analyzer

Autoclave

Centrifuge 5415 D

Centrifuge $5417 \mathrm{R}$

Biophotometer

GeneAmp PCR System 9700

Histocentre 2 embedding machine

Inverted Microscope IX81

Megafuge 1.0 R

Microscope BX60

Microtom Hn 40 Ing.,

Microplate-Reader, Model 450

Neubauer cell chamber

Pipette

Power supply

Refrigerated Superspeed Centrifuge RC-5B

Semi-Dry-Blot Fast Blot

Spectrophotometer Ultraspec 3000

SpeedVac concentrator SVC 100H

Thermomixer 5436

Turboblotter $^{\mathrm{TM}}$

UV Stratalinker $^{\mathrm{TM}} \cdot 1800$

X-Ray Automatic Processor Curix 60
Stratagene, Amsterdam

Qiagen, Hilden

Qiagen, Hilden

Applied Biosystem

Applied Biosystem

Webeco, Bad Schwartau

Eppendorf, Hamburg

Eppendorf, Hamburg

Eppendorf, Hamburg

Perkin Elmer

Shandon, Karlsruhe

Olympus, Planegg

Heraeus, Hanau

Olympus, Planegg

Nut hole

BioRad, München

Schütt Labortechnik, Göttingen

Eppendorf, Hamburg

Gibco BRL, Karlsruhe

Sorvall, Langenselbold

Biometra, Göttingen

Amersham Pharmacia,

Braunschweig

Schütt Labortechnik,

Göttingen

Eppendorf, Hamburg

Schleicher \& Schüll, Dassel

Leica, Bensheim

Agfa, Köln 


\subsection{Methods}

\subsubsection{Isolation of nucleic acids}

2.2.1.1 Isolation of plasmid DNA (Sambrook et al., 1989)

\subsection{Small-scale isolation of plasmid DNA}

A single E.coli colony was inoculated in $5 \mathrm{ml}$ of LB medium with the appropriate antibiotic and incubated in a shaker for $16 \mathrm{hrs}$ at $37^{\circ} \mathrm{C}$ with a vigorous shaking. $0.5 \mathrm{ml}$ of this culture was used for making glycerol stock $(0.5 \mathrm{ml}$ of culture and $0.5 \mathrm{ml}$ of glycerol) and rest was centrifuged at $2000 \mathrm{x}$ g for $10 \mathrm{~min}$. The pellet was resuspended in $100 \mu \mathrm{l}$ of solution P1. The bacterial cells were lysed with $200 \mu 1$ of P2 solution and then neutralised with $150 \mu 1$ of $\mathrm{P} 3$ solution. The precipitated solution was centrifuged at $10,000 \mathrm{x} \mathrm{g}$ at $4^{\circ} \mathrm{C}$. The supernatant was transferred into a new tube and centrifugation was done again. The supernatant was transferred into a new tube and $1 \mathrm{ml}$ of $100 \%$ ethanol was added to precipitate the DNA. It was then stored on ice for $15 \mathrm{~min}$, centrifuged at full speed for 20 min, and finally the pellet was washed with $70 \%$ ethanol and after air-drying was dissolved in $30 \mu 1$ of sterile water.

P1

P3

P2

\author{
$50 \mathrm{mM}$ Tris- $\mathrm{HCl}, \mathrm{pH} 8.0$ \\ $10 \mathrm{mM}$ EDTA \\ $100 \mu \mathrm{g} / \mathrm{ml}$ RNase A \\ $200 \mathrm{mM} \mathrm{NaOH}$ \\ $1 \%$ SDS \\ 3.0 M Potassium acetate, $\mathrm{pH} 5.5$
}

\subsection{Large-scale preparation of plasmid DNA}

A single clone was inoculated in $2 \mathrm{ml} \mathrm{LB}$ medium with appropriate antibiotic as a preculture for $8 \mathrm{hrs}$ in $37^{\circ} \mathrm{C}$ shaker. This pre-culture was added in a dilution of 1:100 fold into $100 \mathrm{ml} \mathrm{LB}$ medium with appropriate antibiotic and incubated overnight at $37^{\circ} \mathrm{C}$ with shaking. The culture was centrifuged then at $6,000 \mathrm{x} \mathrm{g}$ for $15 \mathrm{~min}$. The pellet was resuspended in $4 \mathrm{ml}$ of solution P1 and cells were then lysed with $4 \mathrm{ml}$ of P2 and incubated on ice for $5 \mathrm{~min} .4 \mathrm{ml}$ of P3 buffer was added, mixed and incubated on ice for $15 \mathrm{~min}$. The precipitated solution was centrifuged at $20,000 \mathrm{x}$ g for $30 \mathrm{~min}$ at $4^{\circ} \mathrm{C}$. Meanwhile, the column (Qiagen-tip) that was provided with the midi preparation kit was equilibrated with 
$10 \mathrm{ml}$ of QBT solution. After centrifugation the lysate was poured into this equilibrated column, thus, allowing the DNA to bind with the resin present in the bed of the column. The column was then washed twice with $10 \mathrm{ml}$ of solution QC. Finally, the DNA was eluted with $5 \mathrm{ml}$ of QF solution. To precipitate the DNA, $3.5 \mathrm{ml}$ of isopropanol was added, mixed thoroughly and centrifuged at $14000 \mathrm{x}$ g for $30 \mathrm{~min}$ at $4{ }^{\circ} \mathrm{C}$. The DNA pellet was washed with $70 \%$ ethanol and dissolved in $100 \mu$ of TE buffer.

$\begin{array}{ll}\text { QBT } & 750 \mathrm{mM} \text { Sodium chloride } \\ & 50 \mathrm{mM} \text { MOPS }(\mathrm{pH} 7.0) \\ & 15 \% \text { Ethanol } \\ & 0.5 \% \text { Triton } \mathrm{X}-100 \\ \text { QF } & 1 \mathrm{mM} \text { Sodium chloride } \\ & 50 \mathrm{mM} \text { MOPS }(\mathrm{pH} 7.0) \\ \text { QC } & 15 \% \text { Ethanol } \\ & 1.25 \mathrm{M} \text { Sodium chloride } \\ & 50 \mathrm{mM} \text { Tris } / \mathrm{HCl}(\mathrm{pH} 8.5) .\end{array}$

\subsection{Endotoxin free preparation of plasmid DNA}

Endotoxins, also known as lipopolysaccharides (LPS), are cell membrane components of Gram-negative bacteria (e.g. E.coli). During lysis of bacterial cells for plasmid preparation, endotoxin molecules are released from the outer membrane into the lysate. Endotoxins strongly influence transfection of DNA into primary cells and cultured cells like embryonic stem (ES) cells. Increased endotoxin levels lead to sharply reduced transfection efficiencies. Endofree plasmid preparation kit integrates endotoxin removal into standard plasmid preparation procedure. The neutralised bacterial lysate was filtered through a QIAfilter cartridge (provided in kit) and incubated on ice with a specific Endotoxin Removal buffer (patented by Qiagen). The endotoxin removal buffer prevents LPS molecules from binding to the resin in the columns (QIAGEN-tips), thus allowing purification of DNA containing less than 0.1 endotoxin unit per $\mu \mathrm{g}$ plasmid DNA.

2.2.1.2 Isolation of genomic DNA from mouse tail samples (Laird et al., 1991) Lysis buffer I

$100 \mathrm{mM}$ Tris $/ \mathrm{HCl}(\mathrm{pH} 8.0)$ $100 \mathrm{mM} \mathrm{NaCl}$ 


\section{$100 \mathrm{mM}$ EDTA}

$0.5 \%$ SDS

The method was performed according to Laird et al. (1991). 1 to $2 \mathrm{~cm}$ of mouse tail was incubated in $700 \mu \mathrm{l}$ of lysis buffer I containing $30 \mu \mathrm{l}$ Proteinase $\mathrm{K}(10 \mu \mathrm{g} / \mu \mathrm{l})$ at $55^{\circ} \mathrm{C}$ for overnight in Thermomixer 5436. To the tissue lysate, equal volume of phenol was added, mixed by inverting several times, and centrifuged at $10000 \mathrm{x} g$ at RT for $5 \mathrm{~min}$. After transferring the upper aqueous layer into a new tube, the same procedure was repeated, first with 1:1 ratio of phenol and chloroform and then with chloroform alone. Finally, the DNA was precipitated with $700 \mu \mathrm{l}$ of isopropanol, washed with $500 \mu 1$ of $70 \%$ ethanol, dissolved in 100-200 $\mu \mathrm{l}$ of sterile water and incubated at $60^{\circ} \mathrm{C}$ for $10-20 \mathrm{~min}$. DNA was then stored at $4^{\circ} \mathrm{C}$.

\subsubsection{Isolation of genomic DNA from ES cells}

To isolate the DNA from ES cells, cells in a 24 well plate were washed with PBS and incubated overnight in $500 \mu \mathrm{l}$ lysis buffer II at $55^{\circ} \mathrm{C}$. Equal volume of isopropanol was added and mixed for 15 min to precipitate the DNA. After washing with 70\% ethanol, the DNA was transferred into a microcentrifuge cup containing $80 \mu l$ sterile water and incubated at $60^{\circ} \mathrm{C}$ for $10-20 \mathrm{~min}$.

Lysis buffer II

$100 \mathrm{mM}$ Tris/ $\mathrm{HCl}(\mathrm{pH} 8.0)$

$$
\begin{aligned}
& 5 \mathrm{mM} \text { EDTA } \\
& 200 \mathrm{mM} \mathrm{NaCl} \\
& 100 \mu \mathrm{g} / \mathrm{ml} \text { Proteinase K } \\
& 0.2 \% \mathrm{SDS}
\end{aligned}
$$

\subsubsection{Isolation of genomic DNA from cultured blastocysts}

Culturing of blastocysts is described in 2.2.14.3 After culturing, DNA was prepared by incubating the individual embryos with $20 \mu \mathrm{l}$ of lysis buffer II for $4 \mathrm{hr}$ at $60^{\circ} \mathrm{C}$ followed by incubation at $90^{\circ} \mathrm{C}$ for $30 \mathrm{~min}$. Three microliters of embryonic DNA was used for PCR.

$$
\begin{aligned}
& \text { Lysis-buffer II } \\
& 50 \mathrm{mM} \text { Tris/ } \mathrm{HCl}(\mathrm{pH} 8.0) \\
& 0.5 \mathrm{mM} \text { EDTA (pH 8.0) } \\
& 0.5 \% \text { Tween } 20 \\
& 0.2 \mathrm{mg} / \mathrm{ml} \text { Proteinase K }
\end{aligned}
$$




\subsubsection{Preparation of genomic DNA from preimplantation embryos}

Embryos were obtained from superovulated and plugged female mice (2.2.14.1) at the following stages: 1-cell (18-20 hrs p.c.), 2-cell (42-44 hrs p.c.), 4-cell (50-52 hrs p.c.), 8cell (66-72 hrs p.c.), morulae and blastocysts (90-92 hrs p.c.). Individual embryos were collected in a PCR tube $(0.2 \mathrm{ml})$ containing $5 \mu$ Ampuwa $\mathrm{H}_{2} \mathrm{O}$. Samples were repeatedly (2-3 cycles) frozen and thawed $\left(-80^{\circ} \mathrm{C}\right.$ and $\left.95^{\circ} \mathrm{C}\right)$. Then samples were directly used for genotyping by using PCR approach.

\subsubsection{Isolation of total RNA from tissue samples and cultured cells}

(according to Chomczynski and Sacchi, 1987)

Total RNA isolation reagent (Biomol) is an improved version of the single-step method for total RNA isolation described first by Chomczynski and Sacchi (1987). The composition of reagent includes phenol and guanidine thiocyanate in a monophase solution. In order to avoid any RNase activity, homogeniser used for RNA isolation was previously treated with RNase away and DEPC water and special RNase free Eppendorf cups were used during the procedure. $100 \mathrm{mg}$ tissue sample was homogenised in $1 \mathrm{ml}$ of RNA reagent by using a glass-teflon homogeniser. The sample volume should not exceed $10 \%$ of the volume of reagent used for the homogenisation. The homogenate was vortexed and incubated on ice for $5 \mathrm{~min}$ to permit the complete dissociation of nucleoprotein complexes. Then, $0.2 \mathrm{ml}$ of chloroform was added, vortexed and incubated on ice for $5 \mathrm{~min}$. After centrifuging at $8000 \mathrm{x} \mathrm{g}$ for $15 \mathrm{~min}$ at $4^{\circ} \mathrm{C}$, the colourless upper aqueous phase was transferred into a new tube. $500 \mu 1$ of isopropanol was added, solution was mixed by vortexing and RNA was precipitated by centrifugation at $10000 \mathrm{x} g$ for $1 \mathrm{~min}$. Finally, the pellet was washed with 75\% ethanol, and dissolved in 50-100 $\mu 1$ DEPC- $\mathrm{H}_{2} \mathrm{O}$. The RNA was stored at $-80^{\circ} \mathrm{C}$. To isolate total RNA from cultured cells, $350 \mu 1$ of reagent was added to the $6 \mathrm{~cm}$ diameter Petri dish. Cells were collected with a rubber stick and the lysate was transferred into a QIA shredder in $2 \mathrm{ml}$ cup. Probe was then centrifuged for $2 \mathrm{~min}$ at 10000 $\mathrm{x} g$ in order to homogenise. $350 \mu 1$ of $70 \%$ ethanol was added and mixed. Mixture was put in RNeasy mini spin column, centrifuged for $15 \mathrm{sec}$ at $6000 \mathrm{x} \mathrm{g}$ and washed with $700 \mu \mathrm{l}$ RWI buffer. Filter was put into new cup, $500 \mu \mathrm{l}$ of RPE was added and centrifuged for 2 min at $6000 \mathrm{x}$ g. After removing of supernatant, washing with buffer RPI was repeated. Finally filter was put into new $1.5 \mathrm{ml}$ cup, 30- $50 \mu \mathrm{l}$ of DEPC treated $\mathrm{H}_{2} \mathrm{O}$ was added and centrifuged for $1 \mathrm{~min}$ at $6000 \mathrm{x} \mathrm{g}$. 


\subsubsection{Determination of nucleic acid concentrations}

The concentration of nucleic acids was determined spectrophotometrically by measuring absorption of the samples at $260 \mathrm{~nm}$. The quality of nucleic acids, i.e. contamination with salt and protein was checked by the measurements at 230, 280, and 320 $\mathrm{nm}$. The concentration was calculated according to the formula:

$\mathrm{C}=(\mathrm{E} 260-\mathrm{E} 320) \mathrm{fc}$

$\mathrm{C}=$ concentration of sample $(\mu \mathrm{g} / \mu \mathrm{l})$

E $260=$ ratio of extinction at $260 \mathrm{~nm}$

E $320=$ ratio of extinction at $320 \mathrm{~nm}$

$\mathrm{f}=$ dilution factor

$\mathrm{c}=$ concentration (standard) / absorption (standard)

for double stranded DNA : $\mathrm{c}=0.05 \mu \mathrm{g} / \mu 1$

for RNA : $\mathrm{c}=0.04 \mu \mathrm{g} / \mu \mathrm{l}$

for single stranded DNA : $\mathrm{c}=0.03 \mu \mathrm{g} / \mu \mathrm{l}$

\subsubsection{Gel electrophoresis}

Gel electrophoresis is the technique by which mixture of charged macromolecules, especially nucleic acids and proteins, are separated in an electrical field according to their mobility which is directly proportional to macromolecule's charge to mass ratio.

\subsubsection{Agarose gel electrophoresis of DNA}

Agarose gels are used to electrophorese nucleic acid molecules from as small as 50 base pairs to more than 50 kilobases, depending on the concentration of the agarose and the precise nature of the applied electrical field (constant or pulse). Usually, $1 \mathrm{~g}$ of agarose was added in $100 \mathrm{ml} \mathrm{0.5x}$ TBE buffer, and boiled in the microwave to dissolve the agarose, then cooled down to about $60^{\circ} \mathrm{C}$ before adding $3 \mu \mathrm{l}$ ethidium bromide $(10 \mathrm{mg} / \mathrm{ml})$. This $1 \%$ agarose gel was poured into a horizontal gel chamber. 0.5x TBE buffer was used as electrophoresis buffer. Before loading the samples, about 0.1 volume of loading buffer was added and mixed. The samples were then loaded into the wells of the gel and electrophoresis was carried out at a steady voltage (50 - $100 \mathrm{~V})$. Size of the DNA fragments on agarose gels was determined using $1 \mathrm{~kb}$ DNA ladder, which was loaded with samples in parallel slots. DNA fragments were observed and photographed under UV light. 


\subsubsection{Agarose gel electrophoresis of RNA (Hodge, 1994)}

Single-stranded RNA molecules often have complementary regions that can form secondary structures. Therefore, RNA was run on a denaturing agarose gel that contained formaldehyde, and before loading, the RNA was pre-treated with formaldehyde and formamide to denature. $2 \mathrm{~g}$ of agarose was added to $20 \mathrm{ml}$ of 10x MOPS buffer and $148 \mathrm{ml}$ of DEPC water and dissolved by heating in microwave oven. After cooling it to about $50^{\circ} \mathrm{C}, 33.2 \mathrm{ml}$ of formaldehyde $(37 \%)$ was added, stirred and poured into a horizontal gel chamber. RNA samples were prepared as follows:

$10-20 \mu \mathrm{g}$ RNA

$2 \mu 110 \times$ MOPS Buffer

$3 \mu$ Formaldehyde

$7 \mu$ Formamide (40\%)

$1 \mu 1$ Ethidium bromide

$5 \mu 1$ Loading buffer

Samples were denatured at $65^{\circ} \mathrm{C}$ for $10 \mathrm{~min}$ and chilled on ice before loading into the gel. The gel was run at $30 \mathrm{~V}$ at $4^{\circ} \mathrm{C}$ overnight. To determine the size of the nucleic acid fragments on agarose gels, molecular weight ladder (0.24 - 9.5 kb RNA ladder) was loaded with samples in parallel slots.

\subsubsection{SDS-PAGE of proteins (Laemmli, 1970)}

SDS-Page (Sodium Dodecylsulfate-Polyacrylamide Gel Electrophoresis) can be used for separating proteins for analysis and molecular weight determination. The proteins are denatured and rendered monomeric by boiling in the presence of reducing agents ( $\beta$ mercaptoethanol or dithiothreitol) and negatively charged detergent (SDS). The proteins, which normally differ according to their charges, are all coated with the SDS molecules, which are negatively charged. Hence, all the proteins in the sample become negatively charged and achieve constant charge to mass ratio. In this way, the separation is according to the size of the proteins. A SDS-PAGE consists of two gels; firstly a 10-12\% separating gel was poured. In order to achieve a smooth boundary between separating and stacking gel, the separating gel was covered with a layer of water. After polymerisation of the separating gel, a $4 \%$ stacking gel was poured over it. The samples were heated in $70^{\circ} \mathrm{C}$ NuPage SDS sample buffer for $10 \mathrm{~min}$ before loading into the gel. The gel was run in NuPage MOPS SDS running buffer at $15 \mathrm{~mA}$ for $1 \mathrm{hr}$, then at a constant current of $30 \mathrm{~mA}$. 


\subsubsection{Isolation of DNA fragments from agarose gel}

\subsubsection{Glass silica method (Vogelstein and Gillespie, 1979)}

For the isolation of DNA fragments of 300-4000 base pairs (bp) in length from agarose gels, the QIAEX II Gel Extraction System kit from Qiagen was used. The principle of this method depends on the binding capacity of DNA to silica in high salt concentrations and elution in low salt solutions. After separation of DNA on an agarose gel, the DNA fragment to be isolated was excised with a razor blade and weighed. DNA isolation was performed according to protocol in QIAEXII handbook supplied with the kit.

\subsubsection{QIAquick gel extraction method}

This method is designed to extract and purify DNA of $70 \mathrm{bp}$ to 10 kilobase pairs $(\mathrm{kb})$ in length from agarose gels. Up to $400 \mathrm{mg}$ agarose can be processed per spin column. The principle of this method depends on selective binding of DNA to uniquely designed silicagel membrane. Excised DNA fragments in agarose were isolated as described in QIAquick Spin Handbook supplied by producer (Qiagen).

\subsubsection{Enzymatic modifications of DNA}

\subsubsection{Digestion of DNA using restriction enzymes}

Restriction enzymes are class of bacterial enzymes that cut DNA at specific sites. In bacteria their function is to destroy foreign DNA, such as that of bacteriophages. This attribute of restriction endonucleases is widely utilized in molecular biology. Restriction enzyme digestions were performed by incubating double-stranded DNA with an appropriate amount of restriction enzyme in its respective buffer as recommended by the supplier, and at the optimal temperature for that specific enzyme. Standard digestions include 2-10 U enzyme per microgram of DNA. These reactions were usually incubated for 1-3 hrs to ensure complete digestion at the optimal temperature for enzyme activity, which was typically $37^{\circ} \mathrm{C}$. However, for genomic DNA digestion the reaction solution was incubated overnight at $37^{\circ} \mathrm{C}$.

\subsubsection{Ligation of DNA fragments}

The ligation of an insert DNA into a vector (digested with appropriate restriction enzyme) was carried out in the following reaction mix:

30 ng vector DNA (digested) 
50-100 ng insert DNA (1:3, vector: insert ratio)

$1 \mu 1$ ligation buffer $(10 \mathrm{x})$

$1 \mu 1 \mathrm{~T} 4$ DNA ligase $(5 \mathrm{U} / \mu \mathrm{l})$

in a total volume of $10 \mu 1$

Blunt-end ligations were carried out at $16^{\circ} \mathrm{C}$ for overnight, whereas overhang-end ligations were carried out at $4^{\circ} \mathrm{C}$ overnight.

\subsubsection{Phenol-chloroform extraction and ethanol precipitation}

Protein impurities were removed by vigorous shaking of nucleic acid solution with an equal volume of phenol/chloroform/isoamyl alcohol mixture (25:24:1). The emulsion was then centrifuged for $5 \mathrm{~min}, 10000 \mathrm{xg}$, at RT, and the upper aqueous phase was collected, mixed with an equal volume of chloroform and centrifuged ( $5 \mathrm{~min}, \mathrm{RT}, 10000 \mathrm{xg}$ ). Finally, the upper aqueous phase was collected for precipitation. Nucleic acids were precipitated by addition of $\mathrm{NaAc}$ (final conc. $0.3 \mathrm{M}$ ) and 2.6 volume of absolute ethanol. The mixture was then vortexed and centrifuged $\left(5 \mathrm{~min}, 4^{\circ} \mathrm{C}, 10000 \mathrm{x} \mathrm{g}\right)$. The pellet was washed with $70 \%$ ethanol and centrifuged ( $5 \mathrm{~min}$, RT, $10000 \mathrm{x} \mathrm{g}$ ). After washing, the supernatant was aspirated and the pellet was air dried. The dried pellet was redissolved in sterile RNase free water or TE buffer.

2.2.5.4 TA-Cloning (Clark, 1988; Hu, 1993)

Taq and other polymerases have a terminal transferase activity that results in the nontemplate addition of a single nucleotide to the 3 ' ends of PCR products. In the presence of all 4 dNTPs, dATP is preferentially added. This terminal transferase activity is the basis of the TA- cloning strategy. For cloning of PCR products, pGEM-T Easy vector systems that have 5 ' $\mathrm{T}$ overhangs were used. The followings were mixed:

$50 \mathrm{ng}$ of pGEM-T Easy Vector

PCR product (1:3, vector to insert ratio)

$1 \mu 1$ T4 DNA Ligase 10x buffer

$1 \mu 1$ T4 DNA Ligase

in a total volume of $10 \mu 1$.

The content was mixed with pipetting and the reaction was incubated for $1 \mathrm{hr}$ at RT. For transformation of the ligation reaction, DH5 $\alpha$ competent cells were used (Invitrogen). 
2.2.5.5 Filling-up reaction (Costa and Weiner, 1994)

To make blunt-end from overhang-end 0.1-4 $\mu \mathrm{g}$ of digested DNA was mixed with 0.05 $\mathrm{mM}$ dNTPs and 1-5 U of Klenow fragment with reaction buffer in a total volume of $50 \mu 1$. The reaction was incubated at $37^{\circ} \mathrm{C}$ for $15 \mathrm{~min}$, and then stopped by heating at $75^{\circ} \mathrm{C}$ for 10 $\min$.

\subsubsection{Transformation of competent bacteria (Ausubel et al., 1994)}

Transformation of the bacteria was done by gently mixing one aliquot of competent bacteria $(50 \mu \mathrm{l})$ with $10 \mu \mathrm{l}$ of ligation reaction. After incubation for $35 \mathrm{~min}$ on ice, bacteria were heat shocked for $20-60 \mathrm{sec}$ at $42^{\circ} \mathrm{C}$ and cooled down for $2 \mathrm{~min}$ on ice. After adding $600 \mu \mathrm{l}$ of S.O.C. medium, bacteria were incubated at $37^{\circ} \mathrm{C}$ with shaking for $1 \mathrm{hr}$ to allow recovery of heat shocked bacteria. They were then plated out on LB-agar plates containing appropriate antibiotic $(50 \mu \mathrm{g} / \mathrm{ml})$, and whenever required $1 \mathrm{mM}$ IPTG and X-Gal $40 \mathrm{mg} / \mathrm{ml}$ were added for "Blue-White" selection.

\subsubsection{Polymerase Chain Reaction (PCR)}

The polymerase chain reaction (PCR) is one of the most important techniques in the field of molecular biology. It is a very sensitive and powerful technique (Saiki et al., 1988) that is widely used for the exponential amplification of specific DNA sequences in vitro by using sequence specific synthetic oligonucleotides (primers). The general principle of PCR starts from a pair of oligonucleotide primers that are designed so that a forward or sense primer directs the synthesis of DNA towards a reverse or antisense primer, and vice versa. During the PCR, the Taq DNA polymerase (a heat stable polymerase) (Chien et al., 1976) catalyses the synthesis of a new DNA strand that is complementary to a template DNA from the $5^{\prime}$ to $3^{\prime}$ direction by a primer extension reaction, resulting in the production of the DNA region flanked by the two primers. It allows the rapid and unlimited amplification of specific nucleic acid sequences that may be present at very low concentrations in very complex mixtures.

\subsubsection{PCR amplification of DNA fragments}

The amplification cycles were performed in an automatic thermocycler. The PCR reaction contains in general, the following substances:

$1 \mu 1 \quad$ DNA 
$1 \mu \mathrm{l} \quad$ Forward primer (10 pmol)

$1 \mu \mathrm{l} \quad$ Reverse primer (10 pmol)

$1 \mu 1 \quad 10 \mathrm{mM}$ dNTPs

$5 \mu 1 \quad$ 10x PCR buffer

$1.5 \mu 1 \quad 50 \mathrm{mM} \mathrm{MgCl} 2$

$1 \mu \mathrm{l} \quad$ Taq DNA polymerase $(5 \mathrm{U} / \mu \mathrm{l})$

Up to $50 \mu 1 \mathrm{H}_{2} \mathrm{O}$

The reaction mixture was placed in a $200 \mu \mathrm{l}$ reaction tube and placed in a thermocycler. A standard PCR program is shown here:

Initial denaturation $\quad 95^{\circ} \mathrm{C} \quad 5 \mathrm{~min}$

\begin{tabular}{|c|c|c|c|}
\hline \multirow[t]{3}{*}{ Elongation } & $95^{\circ} \mathrm{C}$ & $30 \mathrm{sec}$ (denaturation) & \multirow{3}{*}{$30-35$ cycles } \\
\hline & $55^{\circ} \mathrm{C}-65^{\circ} \mathrm{C}$ & $30-45 \mathrm{sec}$ (annealing) & \\
\hline & $72^{\circ} \mathrm{C}$ & 1-2 min (extension) & \\
\hline
\end{tabular}

Final extension $\quad 72^{\circ} \mathrm{C} \quad 10 \mathrm{~min}$

\subsubsection{Reverse transcription PCR (RT-PCR)}

RT-PCR is a technique, which generates cDNA fragments from RNA templates, and thereafter amplifies it by PCR. It is very useful to determine the expression of genes in specific tissues or in different development stages. 1-5 $\mu \mathrm{g}$ of total RNA was mixed with 1 $\mu \mathrm{l}$ of oligo $(\mathrm{dT})_{18}$ primer $(10 \mathrm{pmol} / \mu \mathrm{l})$ and sterile water was added to total volume of $12 \mu \mathrm{l}$. To avoid the possible secondary structure of the RNA, which might interfere with the synthesis, the mixture was heated to $70^{\circ} \mathrm{C}$ for $10 \mathrm{~min}$, and then quickly chilled on ice. After a brief centrifugation, the following were added to the mixture:

$4 \mu \mathrm{l} \quad 5 \mathrm{x}$ First strand buffer

$2 \mu \mathrm{l} \quad 0.1 \mathrm{M} \mathrm{DTT}$

$1 \mu \mathrm{l} \quad 10 \mathrm{mM}$ dNTPs

The content of the tube was mixed gently and incubated at $42^{\circ} \mathrm{C}$ for $2 \mathrm{~min}$. Then, $1 \mu 1$ of reverse transcriptase enzyme (Superscript II) was added and further incubated at $42^{\circ} \mathrm{C}$ for $50 \mathrm{~min}$ for the first strand cDNA synthesis. Then, heating at $70^{\circ} \mathrm{C}$ for $15 \mathrm{~min}$ inactivated the reaction. One $\mu 1$ of the first strand reaction was used for the PCR reaction (as described above). 


\subsubsection{Protein methods}

\subsubsection{Isolation of total protein}

Proteins were extracted from fresh or frozen mouse tissues by homogenization in protein lysis buffer $(150 \mathrm{mM} \mathrm{NaCl}, 10 \mathrm{mM}$ EDTA, $50 \mathrm{mM}$ Tris/HCl, pH7.6, 1\% Triton X-100 and $1 \%$ sodium deoxycholate) containing protease inhibitors $(1 \mu \mathrm{g} / \mu \mathrm{l}$ leupeptin, $3 \mu \mathrm{g} / \mu \mathrm{l}$ aprotinin, $1 \mu \mathrm{g} / \mu \mathrm{l}$ pepstatin). Lysates were sonicated on ice (about 20 impulses) and centrifuged at $12000 \mathrm{xg}$ for $10 \mathrm{~min}$ at $4^{\circ} \mathrm{C}$. Supernatant, containing membrane, organelles and cytosol proteins was collected and stored at $-80^{\circ} \mathrm{C}$, or used immediately for Western blot.

\subsubsection{Determination of protein concentration (Bradford, 1976)}

To determine the protein concentration, Bio-Rad protein assay was employed which is a dye-binding assay based on the differential colour change of a dye in response to various concentrations of protein. The assay is based on the observation that the absorbance maximum for an acidic solution of Coomasie Blue G-250 shifts from 494 to $595 \mathrm{~nm}$ when the binding to protein occurs. The bovine serum albumin (BSA) stock solution of $1 \mathrm{mg} / \mathrm{ml}$ was diluted in order to obtain standard dilutions in range of $10 \mu \mathrm{g} / \mathrm{ml}$ to $100 \mu \mathrm{g} / \mathrm{ml}$. The Bio-Rad's color reagent was diluted 1:5 with $\mathrm{H}_{2} \mathrm{O}$ and filtered through $0.45 \mu \mathrm{m}$ filters. In a 96-well microtiter plate, $20 \mu \mathrm{l}$ of each standard dilution and the samples to be measured were pipetted with $280 \mu 1$ of the colour reagent. The absorption of the colour reaction was measured at $595 \mathrm{~nm}$ in a microplate reader (Microplate Reader 450, Bio-Rad).

\subsubsection{Blotting techniques}

\subsubsection{Southern blotting of DNA to nitrocellulose filters (Southern, 1975)}

In Southern blotting, the transfer of denatured DNA from agarose gels to nitrocellulose membrane is achieved by capillary flow. 20 x SSC buffer, in which nucleic acids are highly soluble, is drawn up through the gel into the nitrocellulose membrane, taking with it the single-stranded DNA that becomes immobilised in the membrane matrix. After electrophoresis of DNA, the gel was treated for 10 min with $0.25 \mathrm{M} \mathrm{HCl}$ for depurination. It was followed by denaturation solution for $30 \mathrm{~min}$ and $30 \mathrm{hrs}$ in neutralization solution. The transfer of the DNA to the nitrocellulose membrane was done in a Turbo-Blotapparatus (Schleicher \& Schuell, Dassel). About 24 Whatman filter papers (GB 003) were layered on a Stack Tray followed by 3 Whatman filter papers (GB 002) and 1 Whatman 
filter paper GB 002 soaked with 2 x SSC. The equilibrated nitrocellulose filter that was also soaked with $20 \mathrm{x}$ SSC was laid on the top. The agarose gel, which was treated as described above was placed on the filter, and was covered with 3 Whatman filter papers GB 002 soaked with 20 x SSC. The buffer tray was placed and filled with $20 \times$ SSC. Finally a wick, which was soaked with $20 \mathrm{x}$ SSC, and the wick cover were put on the top of the blot. The transfer was carried out for overnight. Finally, after disassembling of the blot, the filter was dried on air and the DNA was fixed onto the filter by either baking it at $80^{\circ} \mathrm{C}$ for $2 \mathrm{hrs}$ or by UV-crosslinking in UV Stratalinker 1800.

\subsubsection{Northern blotting of RNA onto nitrocellulose filters}

For the transfer of RNA onto a nitrocellulose filter, the same procedure as described above (2.2.9.1) was performed. In this case, however, the gel does not need to be denatured, but was transferred directly onto the nitrocellulose filter, as described in section 2.2.9.1.

2.2.9.3 Western blotting of protein onto PVDF membrane (Gershoni and Palade, 1982)

Semi-dry transfer buffer $(1 \mathrm{x})$ : $\quad 25 \mathrm{mM}$ Tris $\mathrm{pH} 8.3$

$$
150 \mathrm{mM} \text { Glycin }
$$

$10 \%$ Methanol

After the electrophoresis of proteins on a SDS-PAGE, the gel and the PVDF membrane, which were cut of the size of the gel, were first moistened with methanol and then equilibrated in semidry transfer buffer. Six pieces of GB004 Whatman filter paper were also cut of the size of the gel. First, three papers soaked with transfer buffer were placed on semi dry transfer machine's lower plate and then equilibrated membrane was placed over them. Next the gel was placed avoiding any air bubbles. Another three Whatman paper soaked with transfer buffer were placed over to complete the sandwich model. The upper plate was placed over this sandwich and the transfer was carried out at $10 \mathrm{~W}(150-250$ $\mathrm{mA}, 39 \mathrm{~V}$ ) for $1 \mathrm{hr}$. For protein dot blot, specified amounts of protein solution in different concentrations were poured onto PVDF membrane. Membrane was air-dried and used for incubation with antibodies. To confirm transfer efficiency of proteins onto nitrocellulose membranes, the gel was incubated for $30 \mathrm{~min}$ in Coomassie blue solution at RT 


\subsubsection{Incubation of protein-bound membranes with antibodies}

The membrane was first incubated in P1 buffer with $5 \%$ non-fat dry milk for $1 \mathrm{hr}$ at RT in order to block unspecific binding sites, followed by incubation with $2 \%$ milk in P1 buffer for $5 \mathrm{~min}$. Membrane was then incubated with a primary antibody at the recommended antibody dilution in P1 buffer with $2 \%$ non-fat dry milk for overnight at $4{ }^{\circ} \mathrm{C}$. Then, the membrane was washed 4 times in P1 buffer with $2 \%$ dry milk for 5 to 10 min and then incubated with the alkaline phosphatase conjugated secondary antibody in P1 buffer with $2 \%$ non-fat dry milk for $1 \mathrm{hr}$ at RT. After this step, the membrane was washed 4 times in P1 with $2 \%$ dry milk, one time in P1 without dry milk and one time in AP buffer for 5 min at RT. Finally, the proteins on the membrane were visualized by an incubation step in the dark with $10 \mathrm{ml}$ of staining solution (alkaline phosphatase substrate solution) for $15 \mathrm{~min}$ and rinsed with water to stop the reaction.

P1 buffer:

$1.5 \mathrm{M} \mathrm{NaCl}$

$1 \mathrm{M}$ Tris/ $\mathrm{HCl} \mathrm{pH} 7.5$

AP buffer:

100 mM Tris- $\mathrm{HCl}$ (pH 9.5)

$100 \mathrm{mM} \mathrm{NaCl}$

$50 \mathrm{mM} \mathrm{MgCl}_{2}$

Staining Solution:

$66 \mu 1 \mathrm{NBT}$

$33 \mu 1$ BCIP

in $5 \mathrm{ml}$ of AP buffer

2.2.10 "Random Prime" method for generation of ${ }^{32}$ P labelled DNA (Denhardt, 1966; Feinberg and Vogelstein, 1989)

Rediprime $^{\mathrm{TM}} \mathrm{II}$ Random Prime Labeling System (Amersham Pharmacia) was used for labelling of DNA probes. The method depends on the random priming principle developed by Feinberg and Vogelstein (1989). The reaction mix contained dATP, dGTP, dTTP, dCTP, Klenow fragment (4 - $8 \mathrm{U}$ ) and random oligodeoxyribonucleotides. Firstly, 10 - 25 ng of DNA were denatured in a total volume of $46 \mu 1$ in boiling water for 10 min and quick chilled on ice for $5 \mathrm{~min}$. After pipetting the denatured probe to Rediprime ${ }^{\mathrm{TM}}$. II Random Prime Labeling System cup, $4 \mu \mathrm{l}$ of $\left[\alpha-{ }^{32} \mathrm{P}\right] \mathrm{dCTP}(3000 \mathrm{Ci} / \mathrm{mmol})$ was added to the reaction mixture. The labelling reaction was carried out at $37^{\circ} \mathrm{C}$ for $0.5-1 \mathrm{hr}$. The labelled probe was purified from unincorporated $\left[\alpha-{ }^{32} \mathrm{P}\right] \mathrm{dCTP}$ by using microspin columns (Amersham Pharmacia). 


\subsubsection{Hybridization of nucleic acids (Denhardt, 1966)}

The membrane to be hybridised was equilibrated in $2 \times \mathrm{SSC}$ and transferred to a hybridisation tube. After adding $8 \mathrm{ml}$ of hybridisation solution and $150 \mu \mathrm{l}$ of sheared salmon DNA, the membrane was incubated for 6 to $8 \mathrm{hrs}$ in the hybridization oven at an appropriate temperature, which was usually $65^{\circ} \mathrm{C}$. Then, the labelled probe was denatured at $95^{\circ} \mathrm{C}$ for $10 \mathrm{~min}$, quick chilled on ice, and added to the hybridisation solution, together with $150 \mu \mathrm{l}$ of sheared salmon DNA. The hybridisation was carried out overnight in the oven. Next day, the filter was washed for 10 min with 2 x SSC at RT. Finally it was washed with $0.2 \times$ SSC containing $0.1 \%$ SDS and then with $0.02 \times \mathrm{SSC}$ at the hybridisation temperature. After drying the filter, it was sealed in plastic foil and exposed to autoradiography overnight to few days (depending on the value of radioactive signal) at $80^{\circ} \mathrm{C}$. The film was developed in X-ray automatic processor Curix 60. If membrane has to be used again, it was stripped in $0.2 \times \mathrm{SSC}$ at $80^{\circ} \mathrm{C}$, until radioactive signal was no longer detected.

\subsubsection{Non-radioactive dye terminator cycle sequencing}

Non-radioactive sequencing was performed with the Dye Terminator Cycle Sequencing-Kit (Applied Biosystem). The reaction products were analysed with automatic sequencer (Mega Base 1000). For the sequencing reaction, four different dye labelled dideoxy nucleotides were used (Sanger et al., 1977), which, when exposed to an argon laser, emit fluorescent light which can be detected and interpreted. The reaction was carried out in a total volume of $10 \mu \mathrm{l}$ containing $1 \mu \mathrm{g}$ plasmid DNA or 100 - $200 \mathrm{ng}$ purified PCR products, 10 pmol primer and $4 \mu 1$ reaction mix (contains dNTPs, dideoxy dye terminators and Taq DNA polymerase). Elongation and chain termination take place during the following program in a thermocycler: 4 min denaturation followed by 25 cycles at $95^{\circ} \mathrm{C}, 30$ sec, denaturation; $55^{\circ} \mathrm{C}, 15 \mathrm{sec}$, annealing; $60^{\circ} \mathrm{C}, 4 \mathrm{~min}$, elongation. After the sequencing reaction, the DNA was precipitated with $1 / 10$ volume $3 \mathrm{M}$ sodium acetate and 2.5 volume $100 \%$ ethanol and washed in $70 \%$ ethanol. The pellet was dissolved in $4 \mu 1$ of loading buffer, denatured at $95^{\circ} \mathrm{C}$ for $3 \mathrm{~min}$, and finally loaded into the sequence gel. 


\subsubsection{Transfection of NIH 3T3 cells with the Brunol1-EGFPC-1and Brunol1- EGFPN-1 constructs}

Approximately $4 \times 10^{5}$. fibroblast cells (NIH 3T3) were plated on a cell culture slide (Falcon) and cultured overnight in $1 \mathrm{ml}$ DMEM medium containing 10\% FCS and penicillin/streptomycin at $37^{\circ} \mathrm{C}$ and $5 \% \mathrm{CO}_{2}$. On the day of the transfection, fresh liposome solution was prepared. $90 \mathrm{ml}$ of HEPES-NaCl buffer warmed to $45-55^{\circ} \mathrm{C}$ was added to a $100 \mathrm{mg}$ aliquot of CLONfectin stock (CLONTECH laboratories. Inc) to make a final concentration of $1 \mathrm{mg} / \mathrm{ml} \mathrm{CLONfectin.} \mathrm{After} \mathrm{gently} \mathrm{vortexing,} \mathrm{mixture} \mathrm{was} \mathrm{placed} \mathrm{on} \mathrm{ice.}$ Two solutions, A and B were prepared in sterile tubes:

\section{Solution A:}

2-4 mg Brunol1-EGFPC-1

$100 \mathrm{ml}$ Serum-free medium

\section{Solution B:}

2-8 mg CLONfectin (1 mg/ml in HEPES-Buffered Saline [HBS])

$100 \mathrm{ml} \mathrm{Serum}$-free medium

Solutions A and B were combined into one tube, mixed gently and incubated at room temperature for 10-30 min. Then $1.8 \mathrm{ml}$ of serum-free medium was added to tube containing the CLONfectin/DNA solution and mixed gently. Old medium was removed from the culture and CLONfectin/DNA/media solution was applied. Cell culture slides were gently moved back and forth to distribute transfection solution evenly. Slides were incubated at $37^{\circ} \mathrm{C}$ for $4 \mathrm{hrs}$ in a $\mathrm{CO}_{2}$ incubator, after this time CLONfectin/DNA containing medium was removed and cells were washed with PBS prewarmed to $37^{\circ} \mathrm{C}$. About $2 \mathrm{ml}$ of fresh complete growth medium was applied and cells were incubated at $37^{\circ} \mathrm{C}$. After $24 \mathrm{hrs}$, cell culture slides were fixed and immunostaining was applied.

\subsubsection{Techniques for recovery and culture of preimplantation embryos}

\subsubsection{Superovulation}

Seven to eight week old female mice were superovulated by intraperitoneal injections of 5 IU of pregnant mare's serum gonadotropin (PMSG, Sigma St Louis, MO, USA) followed 44-48 hrs later by 5 IU of human chorionic gonadotrophin (HCG; Sigma). After the second injection, females were housed overnight with males and were checked by a vaginal plug the following morning. The E0.5 was considered to be 12:00 noon at the day of vaginal plug. 


\subsubsection{Recovery of preimplantation embryos}

1-cell to 8-cell stage embryos were flushed from the oviduct of superovulated females. Plugged female mice (1.5-2.5 days pc) were killed by cervical dislocation. The skin and peritoneum were opened with the large transverse incision to expose the abdominal cavity. The oviducts with the upper part of the uterus were dissected and placed into a drop of M2 medium. Under dissection microscope, the needle attached to a $1 \mathrm{ml}$ syringe was inserted in the fimbrial end of the oviduct. The needle was then held with forceps and oviducts were flashed with $0.05 \mathrm{ml}$ of M2 medium (2.1.5.2.). Embryos were collected with a pipette and washed through several M2 drops. To remove the zona pellucida, embryos were treated in one drop of Tyrode's acid solution and transferred into the drop of M2-medium as soon as their zona pellucida was dissolved. 2 cell and 4 cell stage embryos were incubated in a drop of acutase in order to remove the polar bodies. The collected embryos were washed five times in a drop of PBS and each single embryo was transferred into a PCR cup (0.2 ml) containing $5 \mu \mathrm{dH}_{2} \mathrm{O}$. Those samples were used for genotyping. In order to decrease the possible contamination with maternal cells, 2 cell stage embryos were cultivated in M16 medium at $37^{\circ} \mathrm{C}$ and $5 \% \mathrm{CO}_{2}$ until they developed to expected developmental stages as a 4cell to blastocyst.

\subsubsection{In vitro culture of blastocyst stage embryos}

Embryos were flushed out from the uteri of plugged females at day 3.5 and placed in gelatinized 96-well dish. Embryos were cultured in ES cell medium without the addition of leukemia inhibitory factor. The dish was kept in a humid incubator at $37{ }^{\circ} \mathrm{C}, 5 \% \mathrm{CO}_{2}$ and embryonic outgrowth was scored daily. Every second day, $5 \mu 1$ of fresh medium was added to the wells. DNA was prepared on the fourth day of the culture (2.2.1.4).

\subsubsection{Histological techniques}

\subsubsection{Tissue preparation for paraffin embedding}

The freshly prepared tissues were fixed in Bouin's solution for $24-72 \mathrm{hrs}$ to prevent the alterations in the cellular structure. The tissue to be embedded in paraffin should be free of water. The dehydration process was accomplished by passing the tissue through a series of increasing alcohol concentrations. For this purpose, the tissue was let in 70\%, 80\%, 90\%, $96 \%$ and $100 \%$ ethanol for at least $1 \mathrm{hr}$ at RT. Later, the ethanol was removed from the tissue by incubating it in isopropanol overnight. Tissue was then incubated in different 
mixtures of isopropanol/xylol (histoclear) in ratios 3:1, 1:1 and 1:3 for $30 \mathrm{~min}-1 \mathrm{hr}$ at RT. Then tissue was incubated in 100\% xylol overnight. Further, tissue was incubated in paraplast at $60^{\circ} \mathrm{C}$ overnight. Before embedding, paraplast was changed at least three times. Finally, the tissue was placed in embedding mould and melted paraffin was poured into the mould to form a block. The block was allowed to cool and was then ready for sectioning or stored at $4^{\circ} \mathrm{C}$.

\subsubsection{Sections of the paraffin block}

The paraffin blocks were pre-cut to the optimal size and clamped into the microtom (Hn 40 Ing., Nut hole, Germany). The cut-thickness of the paraffin embedded was for 3 - $7 \mu \mathrm{m}$. The sections were floated on $40^{\circ} \mathrm{C}$ water to allow actual spread and subsequently put onto Superfrost slides. A fine brush was used to transfer the sections to slides. Slides were then dried at $40^{\circ} \mathrm{C}$ and incubated in $80^{\circ} \mathrm{C}$ for about 15 min to get rid off excess of paraffin. Slides were then stored at RT for further analysis.

\subsubsection{Hematoxylin-eosin staining of the histological sections}

The stored slides with the paraffin sections were stained by the following method:

1. Slides were incubated three times in histoclear (Xylol) for $3 \mathrm{~min}$.

2. Incubation in $100 \%, 96 \%, 80 \%, 70 \%$ and $50 \%$ ethanol each for $2 \mathrm{~min}$.

3. $1 \mathrm{~min}$ in $\mathrm{H}_{2} \mathrm{O}$ and then stained for $15 \mathrm{~min}$ in hematoxylin.

4. Running tap water (control) for $10 \mathrm{~min}$, then $1 \mathrm{~min}$ in $\mathrm{dH}_{2} \mathrm{O}$.

5. Eosin $0.1 \%+2$ drops acetic acid for $5 \mathrm{~min}$, then in $\mathrm{dH}_{2} \mathrm{O}$ for $1 \mathrm{~min}$.

6. Incubation in $50 \%, 70 \%, 80 \%, 90 \%, 96 \%$ and $100 \%$ ethanol each for $2 \mathrm{~min}$.

7. Slides were incubated two times in histoclear (Xylol) for $3 \mathrm{~min}$.

\subsubsection{Techniques for production of targeted mutant mice (Joyner, 2000)}

The discovery that cloned DNA introduced into cultured mouse embryonic stem cells can undergo homologous recombination at specific loci has revolutionized our ability to study gene function in vitro and in vivo. This technique allows us to generate any type of mutation in any cloned gene. Over twenty years ago, pluripotent mouse embryonic stem (ES) cells derived from inner cell mass cells of mouse blastocysts were isolated and cultured (Martin, 1981; Evans and Kaufman, 1981). Using stringent culture conditions, these cells can maintain their pluripotent developmental potential even after many passages 
and following genetic manipulations. Genetic alterations introduced into ES cells in this way can be transmitted into the germ line by producing mouse chimeras. Therefore, applying gene targeting technology to ES cells in culture gives the opportunity to alter and modify endogenous genes and study their functions in vivo.

\subsubsection{Production of targeted embryonic stem cell clones}

\subsection{Preparation of EMFI feeder layers}

A frozen vial of EMFI cell was quickly thawed at $37^{\circ} \mathrm{C}$ and transferred to $10 \mathrm{ml}$ EMFI medium. After centrifugation at $2700 \mathrm{X}$ g for $5 \mathrm{~min}$, the cell pellet was gently resuspended in $10 \mathrm{ml}$ EmFi medium and plated on a $50 \mathrm{~mm}$ culture flask. Cells were incubated at $37^{\circ} \mathrm{C}$, $5 \% \mathrm{CO}_{2}$. When the cells formed a confluent monolayer (three days), they were trypsinized, transferred to five $150 \mathrm{~mm}$ dishes and grown until they formed confluent monolayer, or directly treated with mitomycin $\mathrm{C}$. To treat the EmFi with mitomycin $\mathrm{C}$, the medium was removed and $10 \mathrm{ml}$ fresh medium containing $100 \mu \mathrm{l}$ mitomycin $\mathrm{C}(1 \mathrm{mg} / \mathrm{ml})$ was added. After 2-3 hrs of incubation, the monolayer of cells was washed twice with $10 \mathrm{ml}$ PBS. The cells were then resuspended with $10 \mathrm{ml}$ medium, and gentle pipetting dissolved any cell aggregates. The cells were centrifuged, resuspended in EmFi medium and plated onto dishes, which were treated with $0.1 \%$ gelatine for $30 \mathrm{~min}$. The feeder cells were allowed to attach by incubation overnight at $37^{\circ} \mathrm{C}, 5 \% \mathrm{CO}_{2}$ or used after $2 \mathrm{hrs}$ of incubation. Before adding ES cells on the feeder layer, the medium was changed to ES cell medium.

\subsection{Growth of ES cells on feeder layer}

One vial of frozen ES cells was quickly thawed and cells were transferred to a $12 \mathrm{ml}$ tube containing $6 \mathrm{ml}$ ES cell medium. After centrifugation, the cell pellet was resuspended in 5 $\mathrm{ml}$ ES cell medium and plated on $60 \mathrm{~mm}$ dishes containing EmFi cells at $37^{\circ} \mathrm{C}, 5 \% \mathrm{CO}_{2}$. Next day the medium was changed. The second day, cells were washed with PBS, treated with $2 \mathrm{ml}$ trypsin/EDTA at $37^{\circ} \mathrm{C}, 5 \% \mathrm{CO}_{2}$ for $5 \mathrm{~min}$. The cells were gently pipetted up and down to dissolve cell clumps, resuspended with $5 \mathrm{ml}$ ES medium and centrifuged. The cell pellet was resuspended in $10 \mathrm{ml}$ ES cell medium and distributed either to 5 or 6 dishes (60 $\mathrm{mm})$ or to 2 dishes $(100 \mathrm{~mm})$ containing feeder layers. The cells were passaged every second day as described above. 


\subsection{Electroporation of ES cells}

ES cells, which have grown for two days on $100 \mathrm{~mm}$ dishes, were trypsinized. The cell pellet was resuspended in $20 \mathrm{ml}$ PBS and centrifuged. The cell pellet was then resuspended in $1 \mathrm{ml}$ PBS. Cell suspension $(0.8 \mathrm{ml})$ was mixed with $40 \mu \mathrm{g}$ of linearized DNA-construct and transferred into an electroporation cuvette. The electroporation was performed at 240 $\mathrm{V}, 500 \mu \mathrm{F}$ with the BIO RAD gene pulser ${ }^{\mathrm{TM}}$. After electroporation, the cuvette was placed on ice for $20 \mathrm{~min}$. The cell suspension was transferred from cuvette into $20 \mathrm{ml}$ of ES cell medium and plated onto two $100 \mathrm{~mm}$ dishes containing feeder layers. The medium was changed every two days. Two days after the electroporation, the drugs for the selection were added (active G418 at 150-250 $\mu \mathrm{g} / \mathrm{ml}$ and gancyclovir at $2 \mu \mathrm{M}$ ). The medium was changed every day. After about eight days of selection, drug resistant colonies have appeared and were ready for screening by Southern blot analysis.

\subsection{Analysis of recombinant ES cells}

The drug resistant colonies that were formed after about eight days of selection were picked with a drawn-out Pasteur pipette under a dissecting microscope. Each colony was transferred into a 24 well plate containing feeders and ES cell medium. After 2 days, the ES cells were trypsinized for $5 \mathrm{~min}$ and resuspended in $500 \mu \mathrm{l} \mathrm{ES}$ cell medium. Half of the cell suspension in each well was transferred to a well on two different 24 well plates, one gelatinised plate, and the other containing feeder cells (master plate). The gelatinised plate was used for preparing DNA and the master plate was kept frozen. Prepared DNA was subjected for Southern blot analysis.

\subsubsection{Production of chimeras}

The ability of mammalian embryos to incorporate foreign cells and develop as chimeras has been exploited for a variety of purposes including the perpetuation of mutations produced in embryonic stem (ES) cells by gene targeting and the subsequent analysis of these mutations. The standard procedure is to inject 10-20 ES cells, which are recombinant for a targeted locus into the blastocoel cavity of blastocysts that have been recovered by flushing the uteri of day 3.5 pregnant mice $(\mathrm{C} 57 \mathrm{BL} / 6 \mathrm{~J})$. After injection, embryos are cultured for a short period (2-3 hrs) to allow re-expansion of the blastocoel cavity, which collapses upon injection. Then the embryos were transferred to the uterine horns of day 3 
CD1 pseudopregnant mice. Pseudopregnant females were obtained by mating 6-8 weeks old oestrous females with vasectomized males.

\subsubsection{Detection of chimerism and mice breeding}

The most convenient and readily apparent genetic marker of chimerism is coat colour. Chimeric males (and sometimes females) are test bred to ascertain contribution of the ES cells to germ line. Once a germ line chimera has been identified, the first priority will be to obtain and maintain the targeted allele in living animals (inbred background). The chimeras were bred with C57BL/6J and with 129/SvJ background mice to compare the phenotype in two different genetic backgrounds.

\subsubsection{Determination of sperm parameters}

\subsubsection{Sperm count in epididymes, uterus and oviducts}

Epididymes of mice were dissected under aseptic condition and put in $0.5 \mathrm{ml}$ of in vitro fertilization (IVF) medium. Spermatozoa were allowed to swim out of the epididymes for 1 hr at $37^{\circ} \mathrm{C}, 5 \% \mathrm{CO}_{2}$. Sperm suspension was diluted $10-40$ times with PBS before counting, when necessary. $5 \mu 1$ of this suspension was put into Neubauer counting chamber and spermatozoa were counted in 8 independent fields (each having an area of $0.0025 \mathrm{~mm}^{2}$ ) under the microscope (Olympus BX60) with 20x magnification. Total spermatozoa were calculated by following formula:

Total Sperm $=$ average No. of sperm $\times 10 \times 500 \times$ B $\quad$ (B is the dilution)

For determination of sperm number in the uterus and the oviducts, Brunol1 deficient males were mated with wild type females. The uteri and oviducts of those mice, which were positive for vaginal plug, were dissected in IVF medium and the spermatozoa were flushed out.

\subsubsection{Determination of sperm abnormalities}

For the determination of sperm abnormalities, sperm suspensions were spread onto Superfrost slides, air-dried and fixed in 4\% PFA for $10 \mathrm{~min}$ at RT. Slides were then washed $1 \mathrm{~min}$ in $\mathrm{H}_{2} \mathrm{O}$ and then stained $15 \mathrm{~min}$ in haematoxylin. Next, they were washed in running tap water for approximately 10 min and finally stained with eosin $(0.1 \%+2 \%$ acetic acid $)$ for $1 \mathrm{~min}$ and washed in $\mathrm{H}_{2} \mathrm{O}$ for $1 \mathrm{~min}$. 200 spermatozoa were counted and designed as 
normal or abnormal (normal or unusual sperm head shape). Percentage of abnormal sperm was determined.

\subsubsection{Sperm motility}

$10 \mu 1$ of sperm suspension was put on a dual sided sperm analysis chamber. Sperm motility was quantified using the computer assisted semen analysis (CASA) system (CEROS version 10, Hamilton Thorne Research). Then, 5000-10000 spermatozoa from 3 mice of mutant line and 2 of wild type were analyzed using the following parameters: average path velocity (VAP), straight line velocity (VSL), curvilinear velocity (VCL), lateral head amplitude (ALH), beat frequency (BCF) and straight forward movement (STR). Frequencies of these six sperm motility parameters were examined by probability plots categorised by mouse type (wild-type/mutant) and by time of observation $(1.5,3.5$ and $5.5 \mathrm{hrs}$ after preparation) for statistical analysis.

\subsubsection{Acrosome reaction}

Spermatozoa were isolated and capacitated by incubating for $1 \mathrm{hr}$ at $37^{\circ} \mathrm{C}, 5 \% \mathrm{CO}_{2}$. Sperms were transferred into two microcentrifuge tubes and centrifuged for $2 \mathrm{~min}$ at $3000 \mathrm{x}$ g. The supernatant was aspirated, leaving only $50 \mu \mathrm{l}$ for resuspension of sperms. $2.5 \mu \mathrm{l}$ of Ionophore A23187 (final concentration $10 \mu \mathrm{m}$ in DMSO) was added to sperm suspension. For negative control $2.5 \mu 1$ of phosphoric acid $(5 \mathrm{mM})$ was added and incubated at $37^{\circ} \mathrm{C}$ for $1 \mathrm{hr}$. The sperms were then fixed in $500 \mu \mathrm{l}$ of $2 \%$ formaldehyde (in PBS) for $30 \mathrm{~min}$ at $4^{\circ} \mathrm{C}$. After completion of fixation, sperms were centrifuged at $4000 \times \mathrm{g}$ for $2 \mathrm{~min}$. Sperms were further washed twice with $0.15 \mathrm{mM}$ ammonium acetate. Finally they were resuspended in $100 \mu \mathrm{l}$ of PBS and $30 \mu \mathrm{l}$ of suspension was spread on superfrost slide and air-dried. The slides were stained with Coomasie $\mathrm{G}-250$ in $3.5 \% \mathrm{H}_{2} \mathrm{O}_{2}$ for 2.5 min. Unbound dye was removed by washing several times with water. The slides were mounted with $30 \%$ glycerol and observed under microscope. At least 200 sperms with and without blue head were counted. Here, blue head sperms mean those sperms which failed to undergo acrosome reaction. The acrosome reaction was calculated as follows:

$$
\text { Acrosome reaction (in percentage) }=\frac{\text { Number of sperm without blue head }}{\text { Total number of sperm }} \times 100
$$




\subsubsection{Computer analysis}

For the analysis of the nucleotide sequences, programs like BLAST, MEGABLAST and other programs from National Center for Biotechnology Information (NCBI) were used (www.ncbi.nlm.nih.gov). For restriction analysis of DNA NEBcutter V2.0 programm was used (http://tools.neb.com/NEBcutter2/index.php). Information about mouse alleles, phenotypes and strains were used from Jackson Laboratory (www.informatics.jax.org). For proteins studies ExPASy tools (www.expasy.ch) were used. Mouse genome sequence and other analysis on mouse genes, transcript and putative proteins were downloaded from Celera discovery system ( $\underline{w w w . c e l e r a . c o m})$. For statistical analysis Statistica software

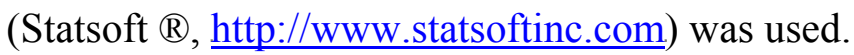




\section{RESULTS}

\subsection{Isolation of the Brunol1 cDNA}

To identify new candidate genes for neurodegenerative diseases, the fetal cDNA library was screened with a probe containing $63 \mathrm{CAG}$ repeats. The complete ORF frame of mouse Brunol1 was isolated.The cDNA of Brunol1 has 1485 nucleotides, consisting of 13 exons and it encodes a protein consisting of 495 amino acids. On position 1161 to 1209, it contains a 16 amino acid long stretch of glutamine. Brunol1 has been mapped on mouse chromosome 1q23. The size of Brunol1 is around $18 \mathrm{~kb}$ due to large size of several introns. Like the other member of elav family, Brunol1 also has three RNA recognition motifs (RRM) and one variable motif (Fig. 3.1 A).

A

\section{RRM1 \\ RRM2 \\ Divergent Domain \\ RRM3}

B 1 atgaaggagccagatgccatcaagctgtttgtggggcagatcccg $\begin{array}{lllllllllllllll}M & K & E & P & D & A & I & K & L & F & V & G & Q & I & P\end{array}$ 46 aggcatctggaggaaaaggacctgaagcccatcttcgagcagttt $\begin{array}{lllllllllllllll}R & H & L & E & E & K & D & L & K & P & I & F & E & Q & F\end{array}$

91 ggtcggatcttcgagctgactgtcatcaaggacaagtacaccggg $\begin{array}{llllllllllllllllll}G & R & I & F & E & L & T & V & I & K & D & K & Y & T & G\end{array}$

136 ctgcacaagggatgtgctttcctgacgtactgtgctcgcgattca $\begin{array}{lllllllllllllllll}L & H & K & G & C & A & F & L & T & Y & C & A & R & D & S\end{array}$

181 gccctgaaggcccagagtgccctgcacgaacagaagactctccca $\begin{array}{llllllllllllllll}A & L & K & A & Q & S & A & L & H & E & Q & K & T & L & P\end{array}$

226 gggatgaacaggccgatccaggtcaagccagccgacagcgagagt $\begin{array}{llllllllllllllllllllllll}G & M & N & R & P & I & Q & V & K & P & A & D & S & E & S\end{array}$

271 cgaggagaagaccggaagctctttgtgggcatgctaggaaagcag $\begin{array}{lllllllllllllll}R & G & E & D & R & K & L & F & V & G & M & L & G & K & Q\end{array}$

316 cagacagatgaggatgtccggaagatgtt tgaaccatt tgggact

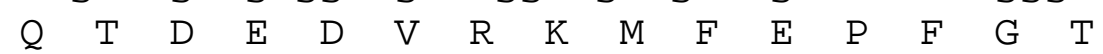

361 atagacgagtgcactgtgctccgggggccagacggtaccagcaaa $\begin{array}{llllllllllllllll} & I & D & E & C & T & V & L & R & G & P & D & G & T & S & K\end{array}$

406 ggctgtgcctttgtgaagttccagactcacgctgaggcccaggca $\begin{array}{lllllllllllllllllllllllll}G & C & A & F & V & K & F & Q & T & H & A & E & A & Q & A\end{array}$

451 gccatcaacacccttcacagcagccggaccctaccgggtgcctca

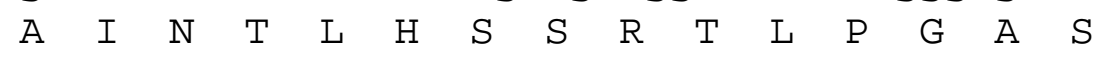

496 tccagcctggtggtaaagtttgctgacacggagaaggagcgaggt

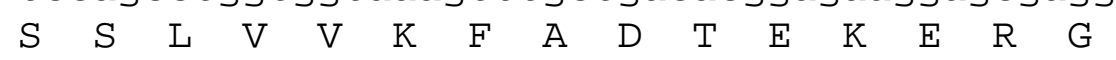

541 ctccgtcgaatgcagcaggtggctacccagctgggcatgttcagc 
$\begin{array}{lllllllllllllll}\mathrm{L} & \mathrm{R} & \mathrm{R} & \mathrm{M} & \mathrm{Q} & \mathrm{Q} & \mathrm{V} & \mathrm{A} & \mathrm{T} & \mathrm{Q} & \mathrm{L} & \mathrm{G} & \mathrm{M} & \mathrm{F} & \mathrm{S}\end{array}$

586 ccgatcgccctccagtttggagcctacagcgectacacccaggcc

$\begin{array}{lllllllllllllll}P & I & A & L & Q & F & G & A & Y & S & A & Y & T & Q & A\end{array}$

631 ctgatgcagcagcaggcggccctggtagcagctcacagtgcctac

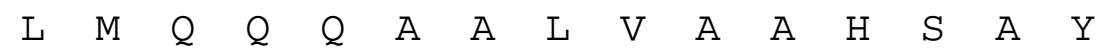

676 ctcagccctatggccaccatggctgccgtgcagatgcagcacatg $\begin{array}{lllllllllllllll}L & S & P & M & A & T & M & A & A & V & Q & M & Q & H & M\end{array}$

721 gctgccatcagtgccaatggcctcatcgccaccccatcactcca $\begin{array}{lllllllllllllll}A & A & I & S & A & N & G & L & I & A & T & P & I & T & P\end{array}$

766 tcctcaggaaccagcacccctcctgccattgctgccacgccogtc $\begin{array}{lllllllllllllll}S & S & G & T & S & T & P & P & A & I & A & A & T & P & V\end{array}$

811 tctgccatccetgctgccttgggcgtcaacggctacagccoggtg

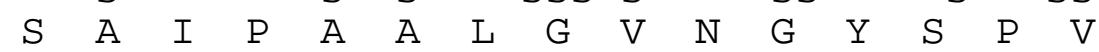

856 cccacccagcctacagggcagcctgccccggatgctctgtatccc $\begin{array}{lllllllllllllll}P & T & Q & P & T & G & Q & P & A & P & D & A & L & Y & P\end{array}$

901 aacggggttcacccttacccagatgaggctctgtctgctgagaga $\begin{array}{lllllllllllllll}N & G & V & H & P & Y & P & D & E & A & L & S & A & E & R\end{array}$

946 agtgctggcggggttcccataatgtcccaggcccactcatggctt $\begin{array}{lllllllllllllll}S & A & G & G & V & P & I & M & S & Q & A & H & S & W & L\end{array}$

991 gtgatgctctctgcagcccagagcccggcagcccccgtggaccct

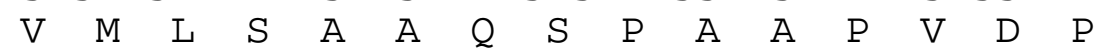

1036 ctccagcaggcctatgcaggaatgcagcactacacagcagcgtac $\begin{array}{lllllllllllllll}L & Q & Q & A & Y & A & G & M & Q & H & Y & T & A & A & Y\end{array}$

1081 cccgcagcctacagcctggttgcacctgcgttcccgcagcctcca $\begin{array}{llllllllllllllll}P & A & A & Y & S & L & V & A & P & A & F & P & Q & P & P\end{array}$

1126 gccotggttgcccagcagccccaccaccacctcagcaacagcag $\begin{array}{lllllllllllllll}A & L & V & A & Q & Q & P & P & P & P & P & Q & Q & Q & Q\end{array}$

1171 cagcagcagcagcagcaacagcaacagcagcagcaacgggaaggc

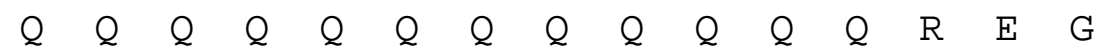

1216 cctgatggctgcaacatcttcatctaccacctgcccaggagttc $\begin{array}{lllllllllllllll}P & D & G & C & N & I & F & I & Y & H & L & P & Q & E & F\end{array}$

1261 acagactcagagatcctccagatgtttgtccctttggtcatgtc $\begin{array}{lllllllllllllll}T & D & S & E & I & L & Q & M & F & V & P & F & G & H & V\end{array}$

1306 atctcagccaaagtctttgttgaccgggccaccaatcagagcaaa $\begin{array}{lllllllllllllll}I & S & A & K & V & F & V & D & R & A & T & N & Q & S & K\end{array}$

1351 tgtttggctttgtgagtttcgacaatccggccagtgcccaggct $\begin{array}{lllllllllllllll}C & F & G & F & V & S & F & D & N & P & A & S & A & Q & A\end{array}$

1396 gccatccaggctatgaacggtttccagattggcatgaagcgcctc $\begin{array}{llllllllllllllll}A & I & Q & A & M & N & G & F & Q & I & G & M & K & R & L\end{array}$

1441 aaagtccagctaaagcggcctaaggatgcaaacaggccctactaa 1485 $\begin{array}{lllllllllllllll}K & V & Q & L & K & R & P & K & D & A & N & R & P & Y & *\end{array}$

Figure 3.1 (A) Schematic representation of Brunol1 protein. (B) Nucleotide sequence of Brunol1 cDNA (from NCBI). ATG codon, indicating start of translation and TAA terminating codon are bold and coloured in blue. 


\subsubsection{Expression analysis of mouse Brunol1 gene}

\subsubsection{Analysis of Brunol1 during embryonic development}

To examine the expression of Brunol1 during embryonic development, RT-PCR analysis was performed with RNA range of different embryonic stages. Brunol1 expression was detected as early as 9.5 days post coitum (dpc) stage (Fig. 3.2 B). Interestingly, expression of Brunol1 was detected in ES cells, but not in early preimplantation stages (2-, 4- and 8-cell stages). Taken together, these data indicate that Brunol1 gene expression starts at $9.5 \mathrm{dpc}$ and is also observed in embryonic stem cells (Fig. 3.2 A).
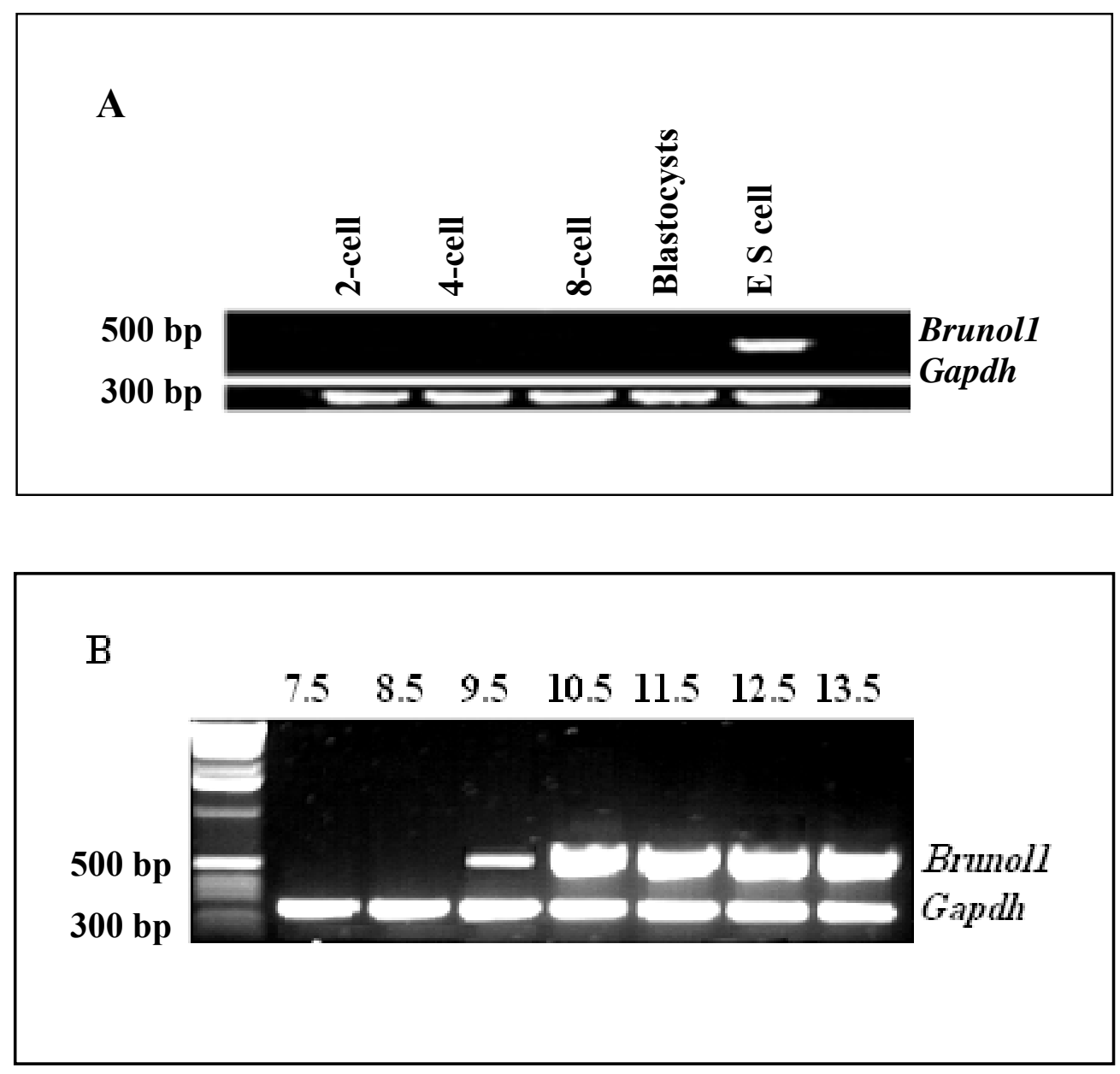

Figure 3.2 RT-PCR expression analysis of Brunol1 during embryonic development.

(A) Preimplantation stages of development. Expression of Brunol1 was detected in ES cells but not in 2-, 4- and 8-cell stages. (B) Postimplantation stages. Expression of Brunol1 starts at early stage 9.5 dpc. Gapdh served as a control. 


\subsubsection{RT-PCR analysis of Brunol1 in adult mouse}

To analyse the expression of Brunol1 in adult mouse at the RNA level, total RNA was isolated from different adult mouse tissues including brain, heart, liver, lung, testis, ovary, muscle and kidney. By RT-PCR analysis, Brunol1 transcript could be detected from samples of brain and testis. Integrity of the RNA used for RT-PCR was proven by amplification of the Gapdh transcript (Figure 3.3 A). RT-PCR was done also with RNA from testes of different mutants with spermatogenesis defects: $\mathrm{W} / \mathrm{W}$., Tfm/y, Leyl-/-, olt/olt and qk/qk. W/W ${ }^{\mathrm{V}}$ mice were characterised by lack of any germ cell (Rooij and Boer, 2003), in Tfm/y and Leyl-/- mutants spermatogenesis is arrested at spermatocyte stage (Lyon and Hawkes, 1970; Zimmermann et al., 1999). Spermatogenesis arrest is known in olt/olt at round spermatid stage and in $\mathrm{qk} / \mathrm{qk}$ at elongated spermatid stage, respectively (Bennett et al., 1971; Moutier, 1976). Brunol1 transcript was detectable in Leyl-/-, olt/olt and $\mathrm{qk} / \mathrm{qk}$ mutants but not in $\mathrm{W} / \mathrm{W}^{\mathrm{V}}$. and $\mathrm{Tfm} / \mathrm{y}$ mutants (Figure $3.3 \mathrm{~B}$ ). This indicates that expression starts as early as in spermatocyte stage. Because there is no expression in $\mathrm{W} / \mathrm{W}^{\mathrm{V}}$ and $\mathrm{Tfm} / \mathrm{y}$ mutants, it can be concluded that expression of the gene is restricted to germ cells. Expression studies were also done in postnatal stages. Brunol1 transcript was detectable from day P20 to P40 in all tested postnatal stages (Figure 3.3 C).
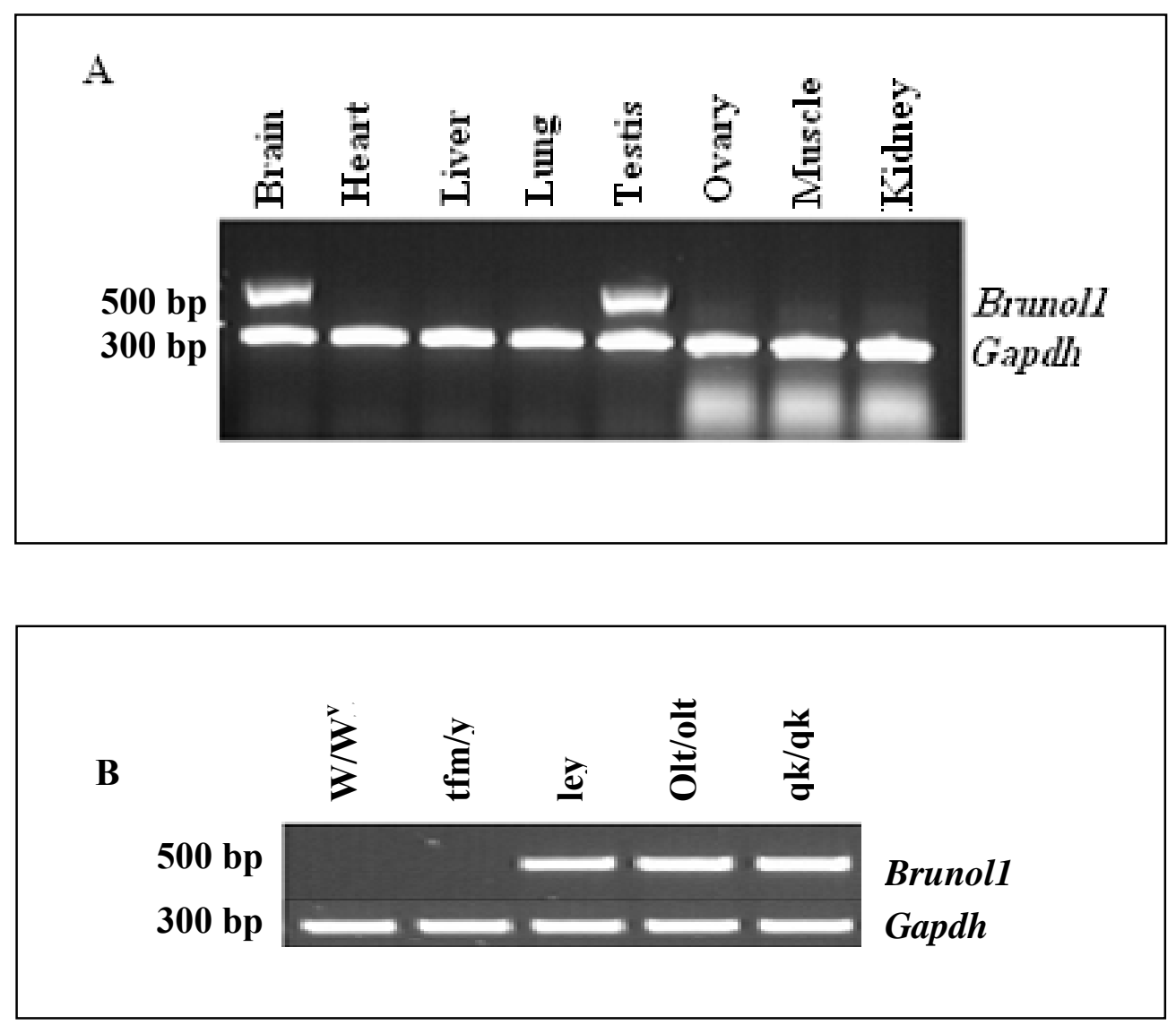


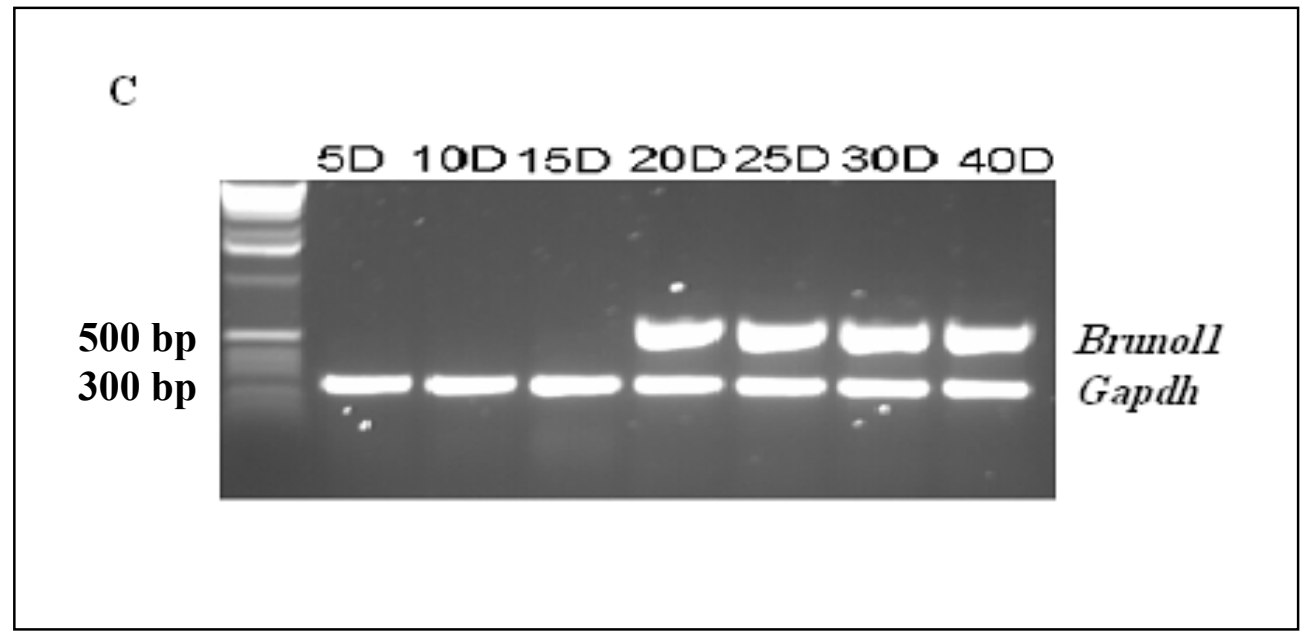

Figure 3.3 RT-PCR expression analysis of Brunol1, (A) in different tissues, (B) in testes of mutants and $(C)$ in postnatal testis development.

\subsubsection{Northern Blot analysis of Brunol1 in adult mouse}

To determine the expression of Brunol1 at the Northern blot level, total RNA from heart, liver, lung, muscle, kidney, ovary, testis and brain was size fractionated in a $1 \%$ agarose/MOPS gel containing $5.5 \%$ formaldehyde and blotted onto Hybond-XL membrane. The Northern blot was hybridised with a ${ }^{32} \mathrm{P}$-labelled 500-bp fragment from the 3' UTR of the murine Brunol1 cDNA probe, which detected approximately $3.0 \mathrm{~kb}$ and 4.0 $\mathrm{kb}$ strong hybridisation signals in whole brain sample and testis. No signal was visible in other adult tissues tested. Integrity of RNA was checked by hybridization with HEF probe (Figure 3.4 )

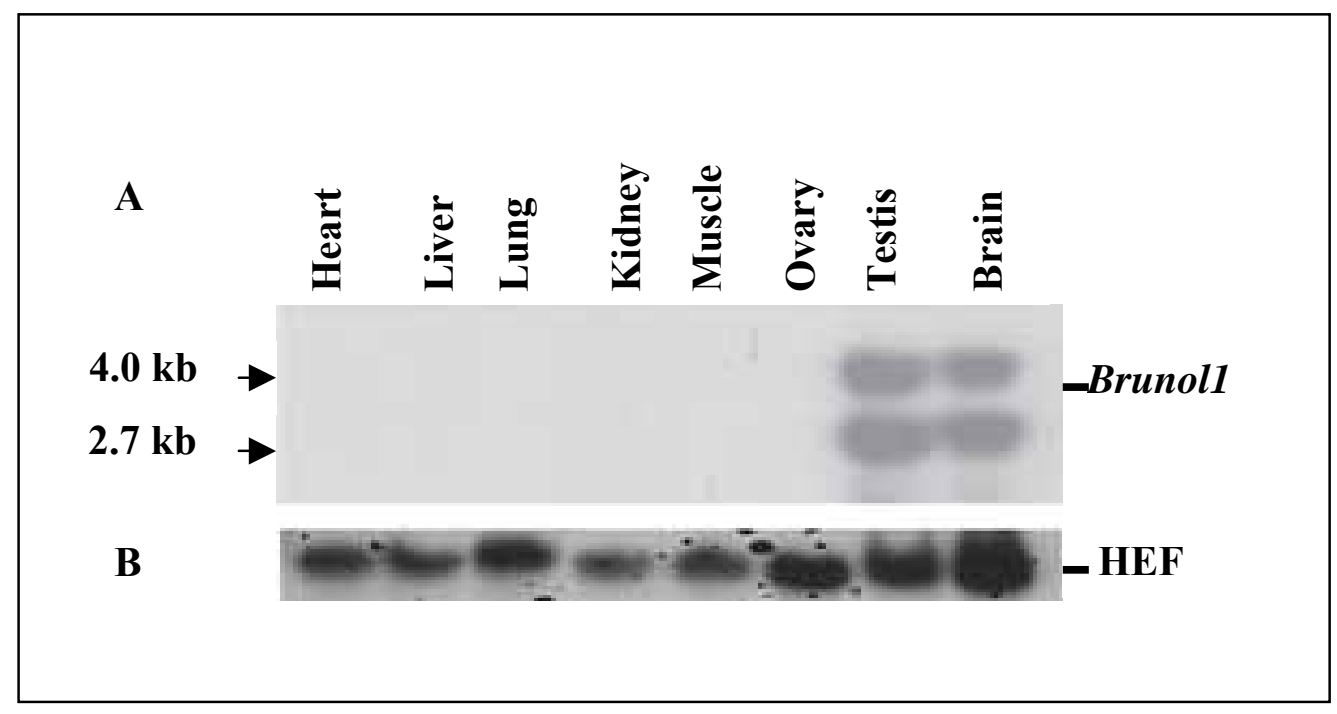


Figure 3.4. Northern blot analysis of Brunol1 gene in different adult mouse tissues. (A) Total RNA (20 $\mu \mathrm{g})$ was extracted from various tissues, heart, liver, lung, muscle, kidney, ovary, testis and brain of the adult mouse and subjected to Northern blot hybridization using the 500-bp fragment from the 3' UTR of Brunol1 as a probe. (B) The integrity of the RNA was checked by hybridization with HEF probe.

\subsubsection{Localisation of Brunol1 protein in the cell}

In order to study the subcellular localization of Brunol1 protein, Brunol1-EGFPC-1and Brunol1-EGFPN-1 fusion protein was generated. Coding region of Brunol1 gene was amplified with Brunol1GFPF and Brunol1GFPR primers and PCR product was checked for mismatches by sequencing. PCR product which showed no mutation was digested with EcoRI and BamHI, as restriction sites for these enzymes were introduced in Brunol1GFPF and Brunol1GFPR primers sequences, respectively. Vector pEGFPN-1 and pEGFPC-1 were digested with the same enzymes and cDNA was cloned. Brunol1EGFP fusion protein is expressed in this case under the control of CMVIE promoter (human cytomegalovirus immediate early promoter) (Fig 3.5). Construct was transiently transfected into cultured NIH3T3 fibroblast cells using Lipofectamin2000 kit, as it was described in section 2.2.13. After 24 hrs, cells were fixed and observed under the microscope using UV light. Taking advantage of green signal emitted from EGFP, we were able to localise Brunoll protein, since Brunol1 and EGFP build fusion protein. Brunoll is localised in the cytoplasm and nucleus (Figure 3.6)

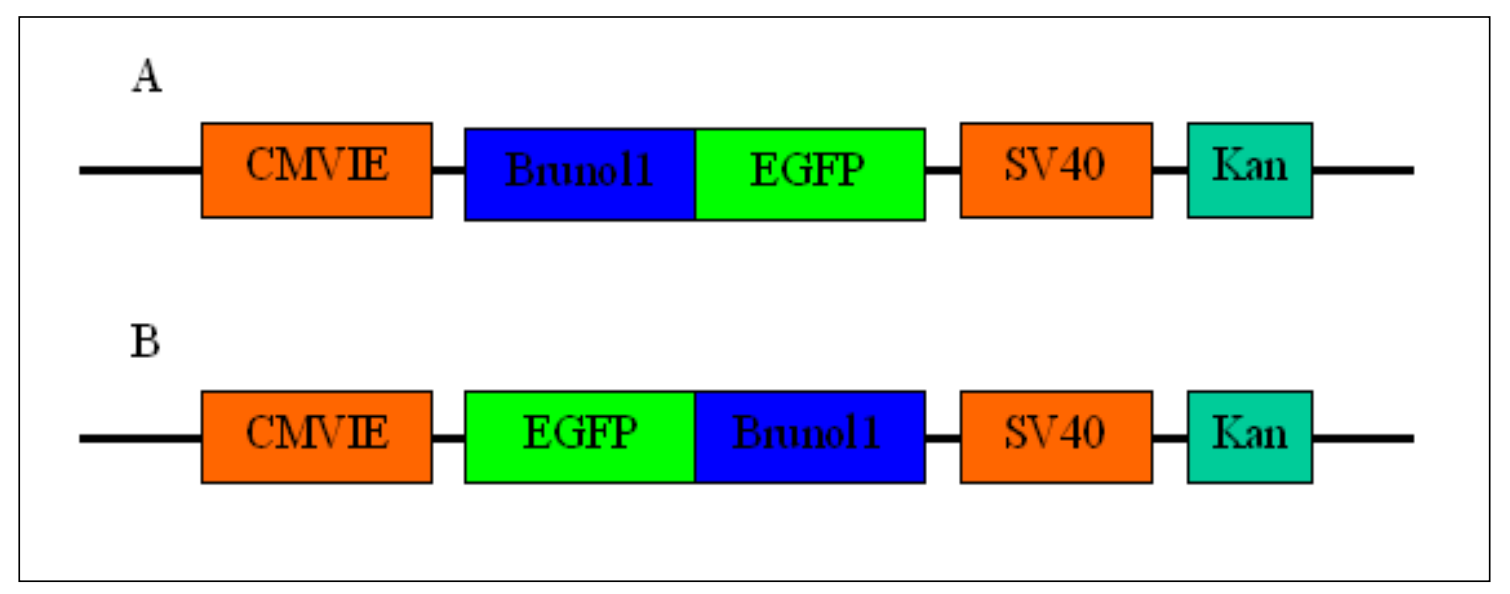


Figure. 3.5 Schematic representation of (A) Brunol1-EGFPC-1 and (B) Brunol1EGFPN-1 construct. Fusion protein was expressed under the control of CMVIE promoter.

DAPI

GFP

Overlay

A

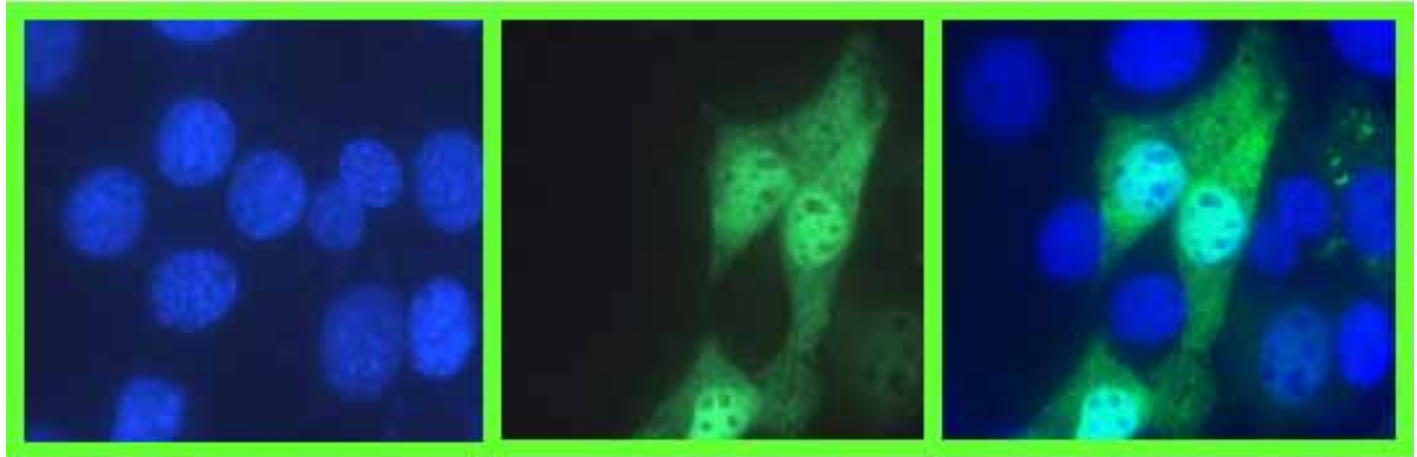

B

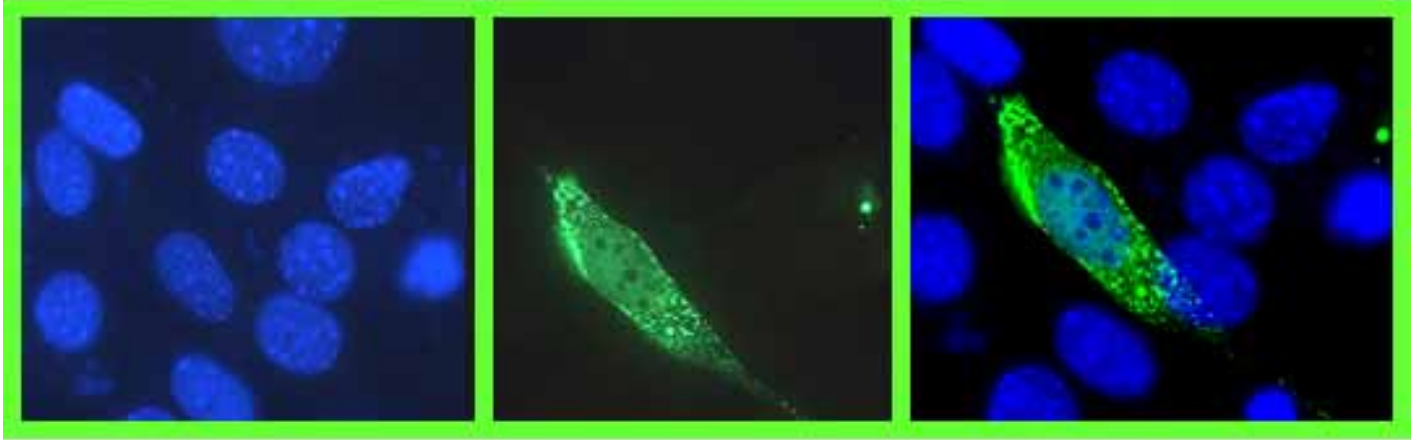

Fig.3.6 Subcellular localisation of Brunol1 protein. Microscopic fluorescence overlay image of transfected NIH3T3 cell expressing Gfp-tagged mouse Brunol1 protein. Green represents Gfp fluorescence from expressed mouse Brunol1 protein, blue represents DAPI-stained cell nuclei. (A) Brunol1-EGFPC-1 and (B)Brunol1-EGFPN-1

\subsubsection{Targeted inactivation of mouse Brunol1 gene}

One of the best ways to elucidate gene function is the generation of a knockout animal model. For this purpose, Brunol1 knockout mice were generated in this study. Analysis of the phenotype of mice with targeted disruption of Brunol1 gene could help in understanding the role of the Brunol1 gene during development and spermatogenesis. 


\subsubsection{Isolation and characterization of the cosmid clone with mouse genomic DNA}

Cosmid clone Mcos115 containing the complete Brunol1 gene was isolated by Schlickum; 1999. We characterized the cosmid clone by restriction digestion and Southern blot analysis. The cosmid clone Mcos115 was restricted with the enzymes XbaI and XhoI, blotted and radioactively hybridized with Brunol1 cDNA probe (Fig 3.7A and 3.7 B).

A

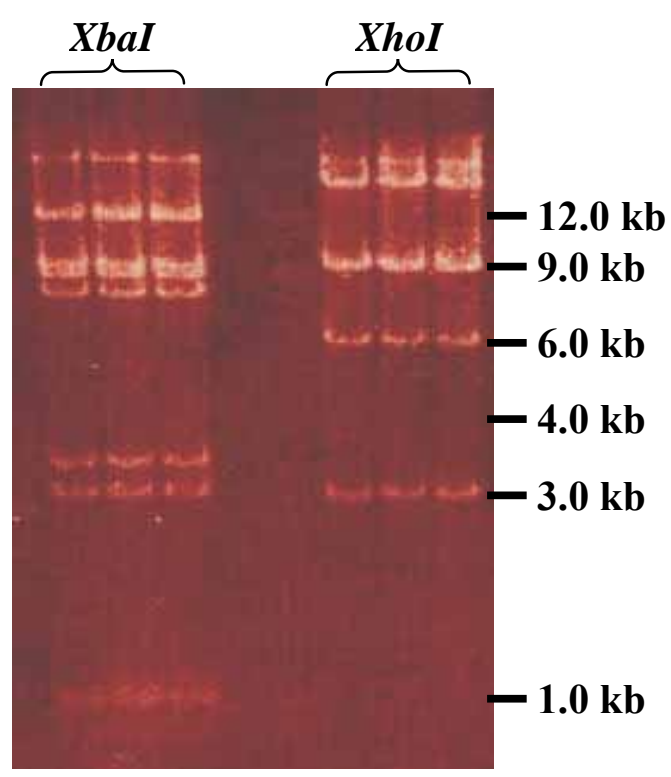

B

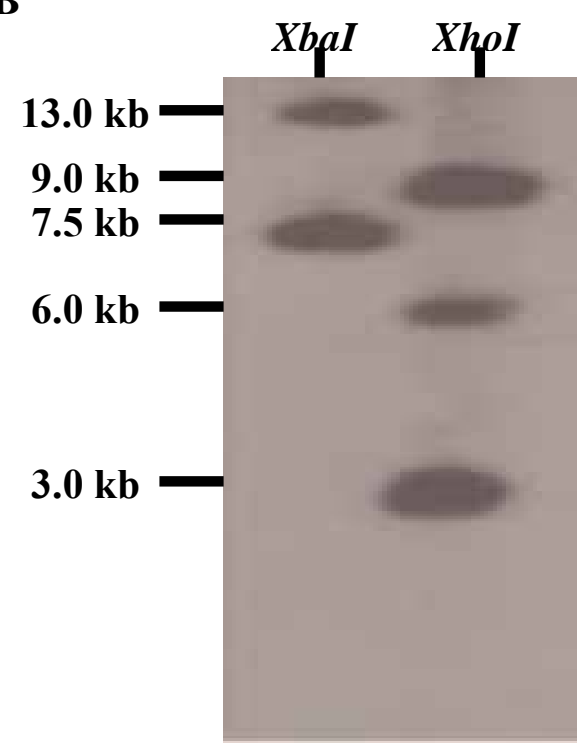

Figure 3.7 (A) Enzymatic digestion of a cosmid clone Mcos115 with XbaI and XhoI. (B) The clone of Mcos115 was digested with $\mathrm{XbaI}$ and XhoI enzymes and hybridized with Brunol1 cDNA probe.

\subsubsection{Construction of the Brunol1 knockout construct}

In order to generate the Brunol1 targeting vector, a region of $7.5 \mathrm{~kb}$ of the Brunol1 gene consisting of exon 3 to exon 12 was replaced by Neomycin phosphotransferase gene cassette under the control of phosphoglycerate kinase promoter. In this construct, neomycin was used as marker for positive selection while two copies of thymidine kinase from Herpes simplex virus was used as a negative selection marker.

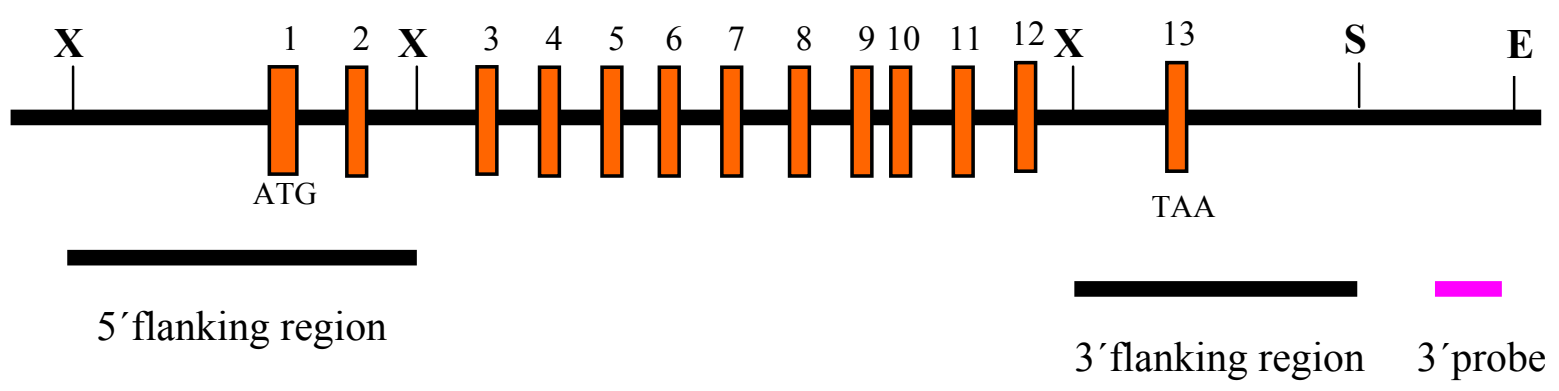


Figure 3.2 Restriction digestion map of Brunol1 genomic DNA and fragments, which were cloned. The cloning strategy for subcloning the 5' and 3' regions of the Brunol1 gene and subcloning of the 3 ' external probe are designated. Abbreviations are: E, EcoRI, X, XhoI and S, SacI.

\subsubsection{Subcloning of 5 ' wing of the Brunol1 knockout construct into the pGATA vector}

The clones which were designated as positive during cosmid library screening were digested with XhoI enzyme. A $6.0 \mathrm{~kb}$ XhoI fragment containing the 5'-flanking region with exon-1 and exon-2 of the Brunol1 gene (Figure 3.8) was isolated from the cosmid clone (Mcos115 from R.Z.P.D) and purified from the agarose gel. This fragment was subcloned into pGATA vector using the XhoI site. The fragment was again extracted from pGATA vector by XhoI enzyme and cloned into the pPNTM-1 vector using the same restriction site.

\subsubsection{Subcloning of 3' wing of the Brunol1 knockout construct into pBlueScriptII SK}

For the generation of 3' wing of the Brunol1 knockout construct, a $9.0 \mathrm{~kb}$ XhoI fragment containing the 3'-flanking region of the Brunol1gene with exon13 (Figure 3.8) was isolated from the cosmid clone (Mcos115 from R.Z.P.D) and purified from the agarose gel. This fragment was subcloned into pBlueScript SK vector using the XhoI site and then $5.0 \mathrm{~kb}$ SacI fragment was extracted from pBlueScript and ligated into pZero vector. Then $5.0 \mathrm{~kb}$ EcoRI fragment from pZero vector was cloned into pPNT-M-1 Neo targeting vector. The replacement vector BrunolI-Neo-Tk; pPNTM-1 Neo vector containing 5'- $6.0 \mathrm{~kb}$ arm and 3'-5.0 kb arm) was sequenced in order to check right orientation of both wings in the vector. Bru-1-6kb-F; Bru-1-6kb-R and Neo-R primers, specific for construct, were used for sequencing and the construct was linearized at the unique NheI site present at the 5'multiple cloning site.

\subsubsection{Generation of the 3 ' external probe}

The 3' external probe for screening of ES cells was generated to distinguish between wild type and recombinant clones. For this purpose, a fragment of $600 \mathrm{bp}$ was amplified by PCR, using primers Bru-1-Ext-Probe-F and Bru-1-Ext-Probe-R. The PCR fragment was cloned in pGEM T-Easy vector and then extracted with EcoRI restriction enzyme. This external probe recognizes a $16 \mathrm{~kb}$ fragment in case of wild type and $11 \mathrm{~kb}$ in case of 
recombinant clone in Southern blot hybridization after digestion of genomic DNA with EcoRI enzyme (Fig 3.7).

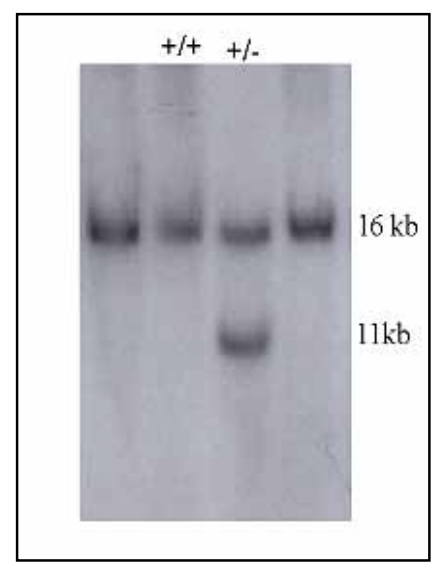

Figure 3.7. Southern blot analysis of ES clones by using 3'external probe. Genomic DNA extracted from ES clones was digested with EcoRI. The external probe recognises a $16 \mathrm{~kb}$ band in case of wild type and $11 \mathrm{~kb}$ in recombinant.

\subsubsection{Electroporation of the ES cells and screening of ES cells for homologous recombination}

Brunol1 targeting vector was linearized with Nhe1 enzyme and $50 \mu \mathrm{g}$ of purified DNA was electroporated into RI embryonic stem cells, as it was described in section 2.2.15.1.3. Cells were plated on feeder layer and after 10 days of selection 98 clones resistant for neomycin were selected and cultured on 24 well plates. Genomic DNA was isolated from ES cells, as it was described in section 2.2.1.3, and used for Southern blot hybridization. DNA from each clone was digested with EcoRI enzyme, electrophoresed and blotted onto Hybond-XL membrane. Blots were then hybridized with radioactively labelled 3 'external probe. Two bands were recognized in case of homologous recombination (16 kb wild type allele and $11 \mathrm{~kb}$ recombinant allele). When no recombination has occurred or nonhomologous recombination had taken place, only wild type band could be detected (Fig 3.8 B). Total 290 clones were screened, out of which three were recombinant. These results were confirmed using Neo probe, which detected $13.5 \mathrm{~kb}$ expected recombinant band. Clone No.128, rehybridized with external probe again and was chosen for blastocyst injection. 

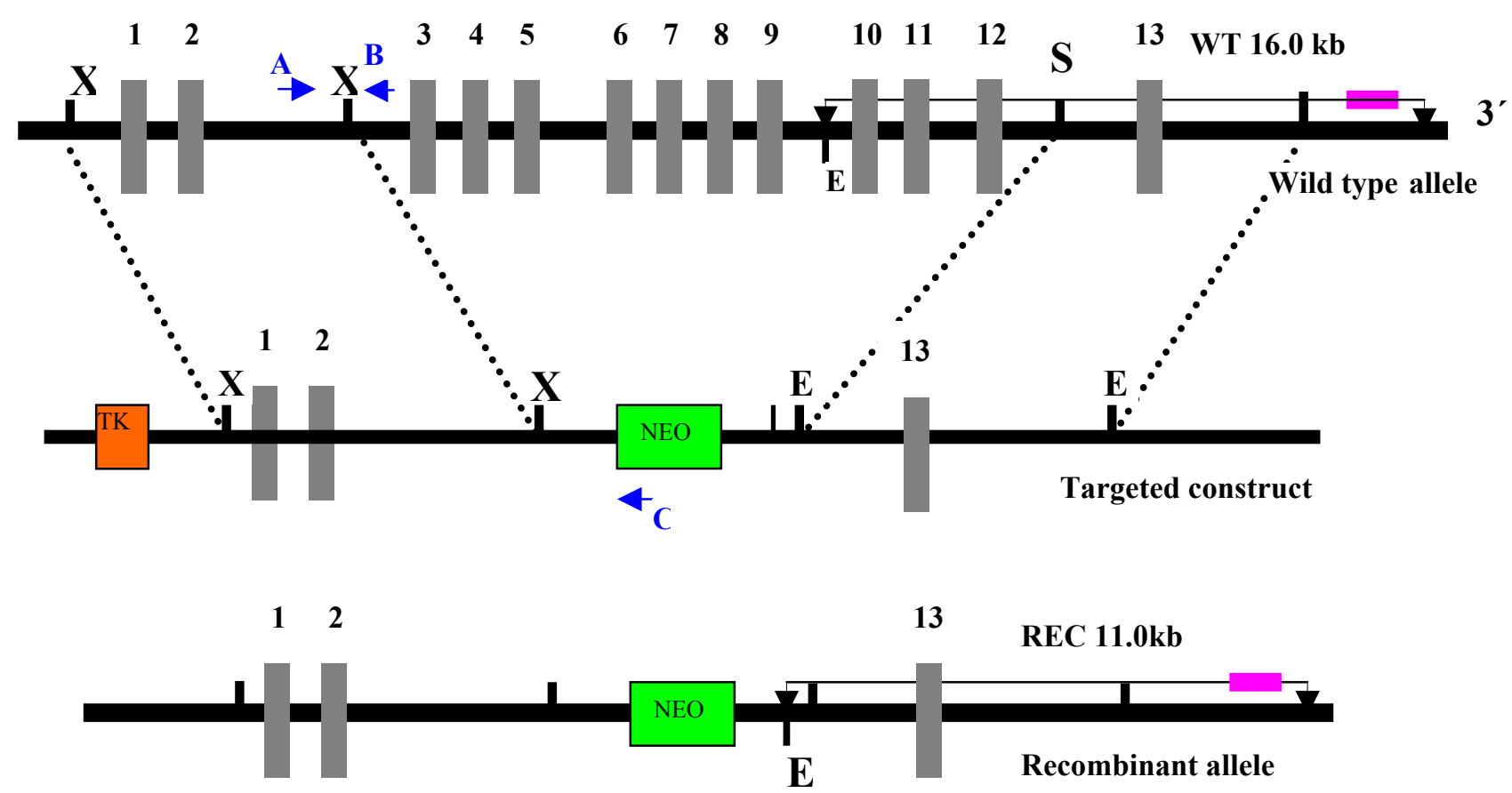

B

C
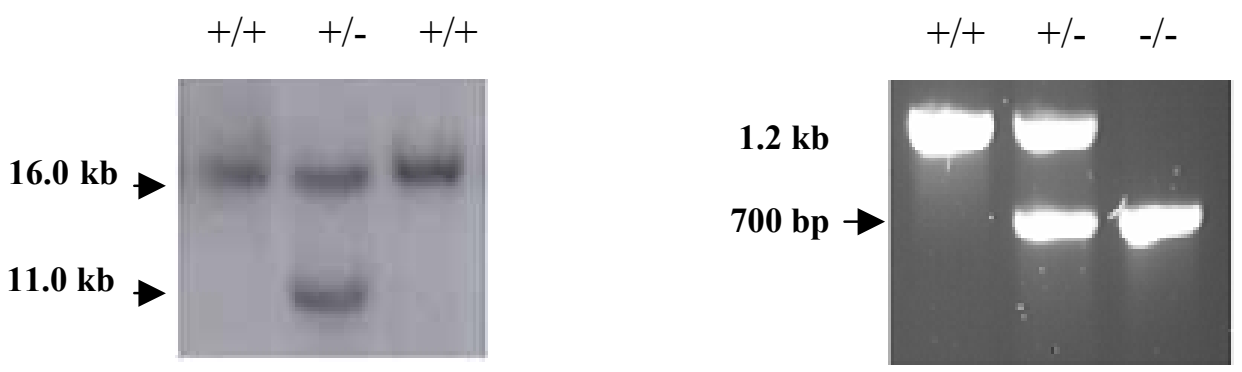

Figure 3.8 Generation of Brunol1 knockout line. A: Schematic representation of the targeting strategy for Brunol1construct. Wild-type Brunol1 locus (top), targeting construct (middle), and mutated allele (bottom) are shown. The Pgk-Neo cassette replaced exon 3 to exon 12 of the Brunol1. The external probe (Ext-probe) shown as a pink block at the $3^{\prime}$ end of Brunol1 locus. The location of various primers are represented by blue arrows, A; Brunol1-F; B, Brunol1-R; C. pGK-NeoR. The exons are shown as numerical numbers. Neo stand for Pgk-Neo cassette The restriction site abbreviations are. X, XhoI; E. EcoRI; S. SacI 


\subsubsection{Generation of chimeric mice}

The recombinant ES cells were injected into 3.5 dpc blastocysts derived from C57BL/6J mice. The blastocysts were implanted into pseudopregnant CD-1 mice to generate the chimeric mice. Total 29 chimeras were obtained by four independent injections of recombinant ES clones. The chimeras were scored according to the coat color (in percentage), 22 male chimeras with 1x 95\%, 3x 85\%, 1x 75\%, 6x 50\%, 3x 25\%, 2x 20\%, $2 \times 15 \%, 4 \times 10 \%$ and 7 female chimeras with $1 \times 45 \%, 1 \times 25 \%, 2 \times 20 \%, 1 \times 20 \% 2 \times 15 \%$, and $2 \times 10 \%$ were obtained. Four high percentage male chimeras $1 \times 95 \%$, 3x 85\%, were bred with C57BL/6J and 129X1/SvJ mice, respectively to obtain F1 animals in respective background (C57BL/6J x 129/Sv) and in (129X1/SvJ). Germ line transmission was detectable by all the four male chimeras on C57BL/6J x Sv/129 and on inbred 129/Sv background after one and half month breeding. The germ line transmission of the mutant allele was verified by genomic PCR. Mutated allele generates an $700 \mathrm{bp}$ PCR product by using Bruno1-Geno-F, Bru-1 Del-R and pGKK-325R primers and wild type yield a PCR product of $1.2 \mathrm{~kb}$ by using the Bruno1-Geno-F, Bru-1 and Del-R primers on DNA isolated from tail biopsies of the offspring (Fig 3.8C).

\subsubsection{Generation and analysis of Brunol1 knockout mice}

F1 animals, heterozygous for Brunol1 were used for further crossing in order to obtain F2 animals and to establish knockout lines on both C57 BL/6J x 129/Sv and 129/Sv background.

\subsubsection{Transcriptional analysis}

In order to assess the Brunol1 transcript in the Brunol1 knockout mice, a Northern blot analysis was performed using testicular RNA from wildtype, heterozygous and homozygous mice of about 50 days of age. The filter was hybridized with the Brunol1 3' UTR cDNA probe. To check the integrity of RNA, the filter was rehybridized with a HEF probe. Northern blot analysis showed the absence of Brunol1 transcript in the Brunol1 ${ }^{-/}$. mice, indicating that, owing due to the integration of the neomycin cassette, the expression of Brunol1 is hampered (Figure 3.9A). By RT-PCR analysis using the testicular RNA from Brunol1 ${ }^{-/}$, heterozygous and wild type mice, PCR product was obtained when RNA from wild type and heterozygous males was used, but not any product was visible in case of RT- 
PCR performed with RNA from homozygous mice. It proves that in homozygous Brunol1 knockout mice the whole Brunol1gene was disrupted (Fig 3.9 B).

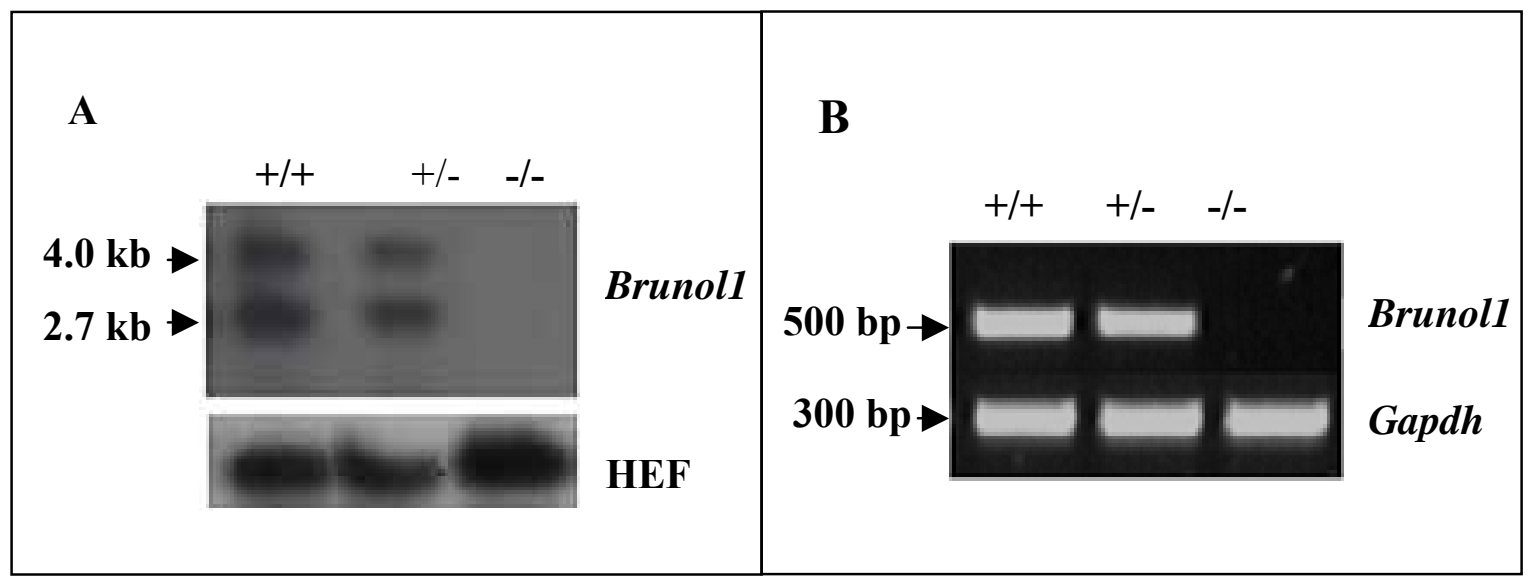

Figure 3.9 Transcriptional analyses of Brunol1 deficient mice. (A) Northern blot analysis of testicular RNA from Brunol1 wild type, heterozygous and homozygous, 50 days old mice. The Brunol1 3'UTR cDNA probe (500 bp) detected a specific transcript of about 3.0 and $4.0 \mathrm{~kb}$. Variation of the loaded RNA was checked by hybridising the same blot with a HEF cDNA probe. (B) RT-PCR analysis for Brunol1 expression in testis. Brunol1 specific product (500 bp) was detected both in the wild type and heterozygous mice, while in Brunol1 ${ }^{-/}$mice no PCR product was detected. Integrity of RNA was verified by Gapdh primers amplification.

\subsubsection{Phenotypic analysis of Brunol1 knockout mice}

\subsubsection{Mode of inheritance}

F1 heterozygous mice were intercrossed to obtain F2 generation. Mice were genotyped using DNA obtained from tail biopsies. Breeding of heterozygous mice with wild type mice were performed for a control. No change in the sex ratio of the offspring of the heterozygous matings was noted in both backgrounds (C57BL/6J x 129/Sv and129/Sv), (Table 3.1A and 3.1C). In addition, there seemed to be no reduction in litter size 9.1 on C57BL/6J x 129/Sv and 5.9 on $129 / \mathrm{Sv}$ in comparison to matings of wildtype animals. The ratio of wildtype, heterozygous and homozygous was approximately 1:2:1 (Table 3.1B). Among the 107 offspring, 35 (31\%) were wild type, 52 (47\%) were heterozygous and 20 (18\%) were homozygous mice (Table 3.1B) in the C57BL/6J x 129/Sv genetic background, 
while in case of 129/Sv inbred background, 27 were wild type, 42 were heterozygous and 30 were homozygous mice out of 97 animals genotyped (Table 3.1D).

A

HE $q$ x WT $̋$ on C57 BL/6J x 129/Sv background

\begin{tabular}{|l|c|c|}
\hline \multirow{2}{*}{ WT } & female & male \\
\cline { 2 - 3 } & $14=53 \%$ & $12=46 \%$ \\
\hline \multirow{2}{*}{ HE } & $13=39 \%$ & $26=44 \%$ \\
\cline { 2 - 3 } & \multicolumn{2}{|c|}{$33=55 \%$} \\
\hline & $27=45 \%$ & $32=54 \%$ \\
\hline
\end{tabular}

B

HE x HE on C57 BL/6J x 129/Sv background

\begin{tabular}{|c|c|c|}
\hline \multirow{2}{*}{ WT } & female & male \\
\cline { 2 - 3 } & $16=16 \%$ & $18=16 \%$ \\
\hline \multirow{2}{*}{ HE } & $29=15 \%$ & $23=24 \%$ \\
\cline { 2 - 3 } & \multicolumn{2}{|c|}{$35=31 \%$} \\
\hline HO & $13=12 \%$ & $10=17 \%$ \\
\cline { 2 - 3 } & $59=53 \%$ & $51=46 \%$ \\
\hline
\end{tabular}

C

HE x WT on 129 SV background

\begin{tabular}{|l|c|c|}
\hline \multirow{2}{*}{ WT } & female & male \\
\cline { 2 - 3 } & $12=22 \%$ & $10=34 \%$ \\
\hline \multirow{2}{*}{ HE } & $17=19 \%$ & $11=25 \%$ \\
\cline { 2 - 3 } & $28=53 \%$ \\
\hline & $29=56 \%$ & $21=41 \%$ \\
\hline
\end{tabular}




\begin{tabular}{|c|c|c|}
\hline \multirow{2}{*}{ WT } & female & male \\
\cline { 2 - 3 } & $12=44 \%$ & $15=56 \%$ \\
\hline \multirow{2}{*}{ HE } & $17=40 \%$ & $25=60 \%$ \\
\cline { 2 - 3 } & \multicolumn{2}{|c|}{$27=27 \%$} \\
\hline HO & $18=60 \%$ & $12=40 \%$ \\
\cline { 2 - 3 } & \multicolumn{2}{|c|}{$30=30 \%$} \\
\hline & $47=48 \%$ & $52=52 \%$ \\
\hline
\end{tabular}

Table 3.1 Statistical analysis of genotype distribution of Brunol1 in HE $x$ WT and HE $x$ HE breeding on C57 BL/6J x 129/Sv and 129/Sv backgrounds. (A) Breeding of heterozygous animals with wild type ones on mixed background did not show significant statistical differences, as it was shown by chi ${ }^{2}$ test. 59 animals in 8 throws were genotyped. (B) Crossing of heterozygous animals on mixed background also did not show deviation from Mendelian ratio. 107 animals in 12 throws were analyzed. (C) On 129/Sv background no deviations from expected numbers were observed when heterozygous animals were crossed with wild type ones. 50 animals in 7 throws were genotyped. (D) No statistically significant difference was observed by chi $^{2}$ test, when breeding of heterozygous animals on 129/Sv background was analyzed. 99 animals in 17 throws were genotyped. Abbreviations are: WT: wild type, HE: heterozygous, HO: homozygous.

\subsubsection{Analysing the fertility of Brunol1 deficient males}

To evaluate consequences of Brunol1 disruption, fertility of homozygous males on both backgrounds were tested by mating them with homozygous and wild type females. All of the matings were performed for four months and usually after one month first litter was obtained. Number of born mice and mean litter size of these breedings together with results of breedings of heterozygous mice are summarized in Table 3.2. Average litter size of offspring of $\mathrm{HO}$ x $\mathrm{HO}$ mating on both backgrounds was not significantly different from litter size of HE x WT and HO x WT matings on the mixed background and from HE x WT mating on $129 / \mathrm{Sv}$ background. The average litter size on $\mathrm{C} 57 \mathrm{Bl} / 6 \mathrm{~J}$ was 7.9 and 7.6 on 
129/Sv background. Eight males from C57 BL/6J x 129/Sv background and 5 males from $129 / \mathrm{Sv}$ background were used for the fertility test. All of the males from both backgrounds were fertile

\begin{tabular}{|c|c|c|c|}
\hline Type of breeding & $\begin{array}{l}\text { No. of mice } \\
\text { born }\end{array}$ & No. of litters & Average litter size \\
\hline \multicolumn{4}{|l|}{ C57BL/6J x 129Sv } \\
\hline$+/-9 \times \mathrm{x}+/+\hat{0}$ & 59 & 8 & 7.3 \\
\hline$+/-x \quad x \quad+/-$ & 110 & 12 & 9.1 \\
\hline$-/-\hat{0} \mathrm{x}+/+q$ & 71 & 8 & 8.8 \\
\hline $\begin{array}{lll}-/- & x & -/-\end{array}$ & 79 & 10 & 7.9 \\
\hline $129 / \mathrm{Sv}$ & & & \\
\hline$+/-\quad \mathrm{x} \quad+/+$ & 51 & 7 & 7.2 \\
\hline$+/-\quad x \quad+/-$ & 117 & 17 & 6.8 \\
\hline$-/-0^{-1} \times \quad+/+q$ & 99 & 16 & 6.1 \\
\hline $\begin{array}{lll}- & x & -/-\end{array}$ & 61 & 8 & 7.6 \\
\hline
\end{tabular}

Table 3.2 Fertility of Brunol1 +/- and Brunol1 -/- mice on C57BL/6J x 129/Sv and 129/Sv backgrounds. Numbers of born mice, number of litters and average litter sizes are given. Average litter size from both backgrounds was not affected.

\subsubsection{Sperm count, acrosome reaction and analysis of sperm morphology of}

\section{Brunol1 deficient mice}

Total sperm count in the cauda epididymes of Brunol1 homozygous, heterozygous and wild type males was determined. Four homozygous, three heterozygous and three wild type males from both genetic backgrounds were used for sperm count. A statistically significant difference in total sperm count was observed between knockout and wild type animals (Table3.3), as determined by Mann-Whitney U-test with a confidence value of $<0.01$. To analyse sperm morphology, slides were prepared as it was described in section 2.2.17 No abnormalities were observed in sperm shape in Brunol1 mutants as compared to wild type 
(Figure 3.10A \& 3.10B). To analyse the acrosome reaction, we examined the response of spermatozoa of Brunol1 $^{+/+}$and Brunol1 $1^{-/-}$to the calcium ionophore A 23187. There was no significant difference in the assay for acrosome reaction between Brunol1./+ $(84 \%)$ and Brunol1 $^{-/-}(79 \%)$ mice.

\begin{tabular}{|c|c|c|}
\hline No of sperm & \multicolumn{2}{|c|}{$\begin{array}{c}\text { Genotype of male } \\
+/+\end{array}$} \\
\hline $\begin{array}{c}\text { C 57BL/6 J x 129Sv } \\
\text { Epididymis }\end{array}$ & $7.0 \pm 0.8 \times 10^{7}$ & $2.0 \pm 0.4 \times 10^{7}$ \\
\hline $\begin{array}{c}129 / \mathrm{Sv} \\
\text { Epididymis }\end{array}$ & $7.2 \pm 1.3 \times 10^{6}$ & $3.0 \pm 1.8 \times 10^{6}$ \\
\hline
\end{tabular}

Table 3.3 Sperm count in the cauda epididymes of $-/-$ and $+/+$ mice from both $\mathbf{C}$ 57BL/6J x 129Sv and 129/Sv backgrounds. Statistically significant differences were observed as compared to wild type.

A

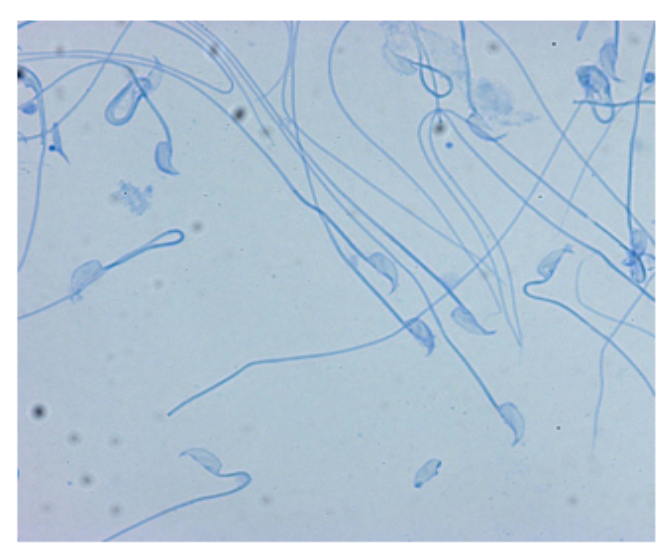

$\mathbf{B}$

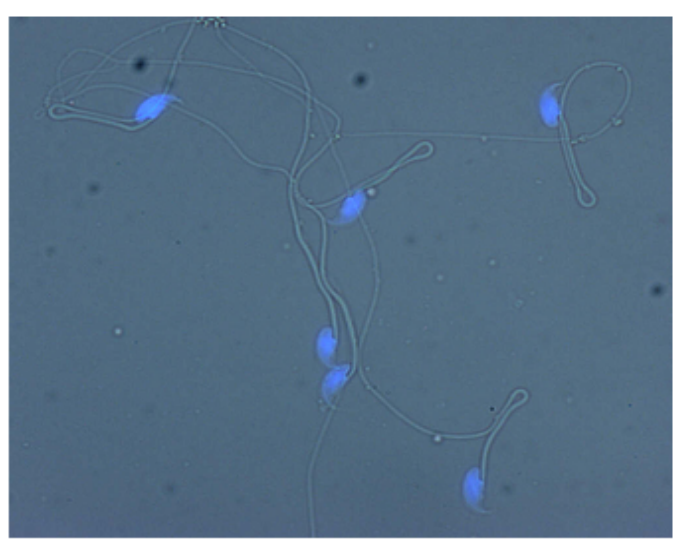

Figure 3.10. No sperm morphology abnormalities were observed with sperm isolated from cauda epididymes of males from (A) C 57BL/6J x 129/Sv and (B) 129/Sv backgrounds 


\subsubsection{Sperm motility assay}

Analysis of sperm motility of Brunol1 ${ }^{-/}$. mice was done on the C57BL/6J x 129/SvJ and 129/Sv backgrounds (Table 3.5). The sperm motility of 2 wildtype males and four mutant males was measured at 1.5, 3.5 and $5.5 \mathrm{hrs}$ incubation in vitro, using the Hamilton Thorne computer assisted sperm analyser, as it was described in section 2.2.22.3. Significant differences in motility and progressive movement of sperm of Brunol1 deficient mice were observed, as compared to wild type. Percentage of motile sperms and sperms showing progressive movement of mutant mice was always 15 - $20 \%$ lower than wild type like $24 \%$ of motile sperm of mutant vs. $58 \%$ of wild type at $1.5 \mathrm{hrs}$ and $36 \%$ of progressive moving sperm of mutant vs. 65 . \% of wild type at $3.5 \mathrm{hrs}$ on mixed background. On 129/Sv background $44 \%$ of motile sperm of mutant vs. $70 \%$ of wild type at $3.5 \mathrm{hrs}$ and $27 \%$ of progressive moving sperm of mutant vs. $38 \%$ of wild type at $3.5 \mathrm{hrs}$ was observed. This data is summarized in Table 3.5.

For further investigation of sperm motility, the following parameters were evaluated more in details: straight forward movement (STR), lateral head amplitude (ALH) curvilinear velocity (VCL), average path velocity (VAP), straight line velocity (VSL) and beat frequency (BCF) (Fig. 3.11). Mann-Whitney U-Test was done and statistically significant differences were observed for almost each parameter with $p<0.001$, with few exceptions. On C57 BL/6J x 129/Sv background significant differences were observed for BCF with $\mathrm{p}=0.004$ at $1.5,3.5$ and at $5.5 \mathrm{hrs}$, significant differences were found for STR at 3.5 hrs with $\mathrm{p}=0.004$. On $129 / \mathrm{Sv}$ background statistically significant differences were found for STR at $1.5 \mathrm{hrs}, \mathrm{BCF}$ at $3.5 \mathrm{hrs}$ and STR at $5.5 \mathrm{hrs}$. Differences were especially high for all velocities and lateral head amplitude. This finding indicates that motility of Brunol1 deficient mice sperm is significantly reduced. 
A

\begin{tabular}{|c|c|c|c|}
\hline Genotype & $\begin{array}{c}\text { Incubation } \\
\text { time (hr) }\end{array}$ & $\begin{array}{c}\text { Percentage of } \\
\text { motile } \\
\text { spermatozoa }\end{array}$ & $\begin{array}{c}\text { Percentage of } \\
\text { spermatozoa } \\
\text { with } \\
\text { progressive } \\
\text { movement }\end{array}$ \\
\hline \multirow{2}{*}{$-/-$} & 1.5 & 24 & 25 \\
\cline { 2 - 4 } & 3.5 & 53 & 36 \\
\hline \multirow{2}{*}{$+/+$} & 5.5 & 58 & 30 \\
\cline { 2 - 4 } & 1.5 & 58 & 65 \\
\cline { 2 - 4 } & 3.5 & 64 & 49 \\
\hline & 5.5 & 71 & 66 \\
\hline
\end{tabular}

B

\begin{tabular}{|c|c|c|c|}
\hline \multirow{2}{*}{ Genotype } & $\begin{array}{c}\text { Incubation time } \\
\text { (hr) }\end{array}$ & $\begin{array}{c}\text { Percentage of } \\
\text { motile } \\
\text { spermatozoa }\end{array}$ & $\begin{array}{c}\text { Percentage of } \\
\text { spermatozoa } \\
\text { with } \\
\text { progressive } \\
\text { movement }\end{array}$ \\
\hline \multirow{2}{*}{$-/-$} & 1.5 & 48 & 30 \\
\cline { 2 - 4 } & 3.5 & 44 & 27 \\
\cline { 2 - 4 } & 5.5 & 35 & 20 \\
\hline \multirow{2}{*}{$+/+$} & 1.5 & 70 & 38 \\
\cline { 2 - 4 } & 3.5 & 67 & 27 \\
\cline { 2 - 4 } & 5.5 & 71 & 42 \\
\hline
\end{tabular}

Table 3.5 Motility analysis of sperm from Brunol1 deficient males on (A) C57 BL/6J x 129/Sv background and (B) 129/Sv background. 


\section{Average path velocity (VAP)}
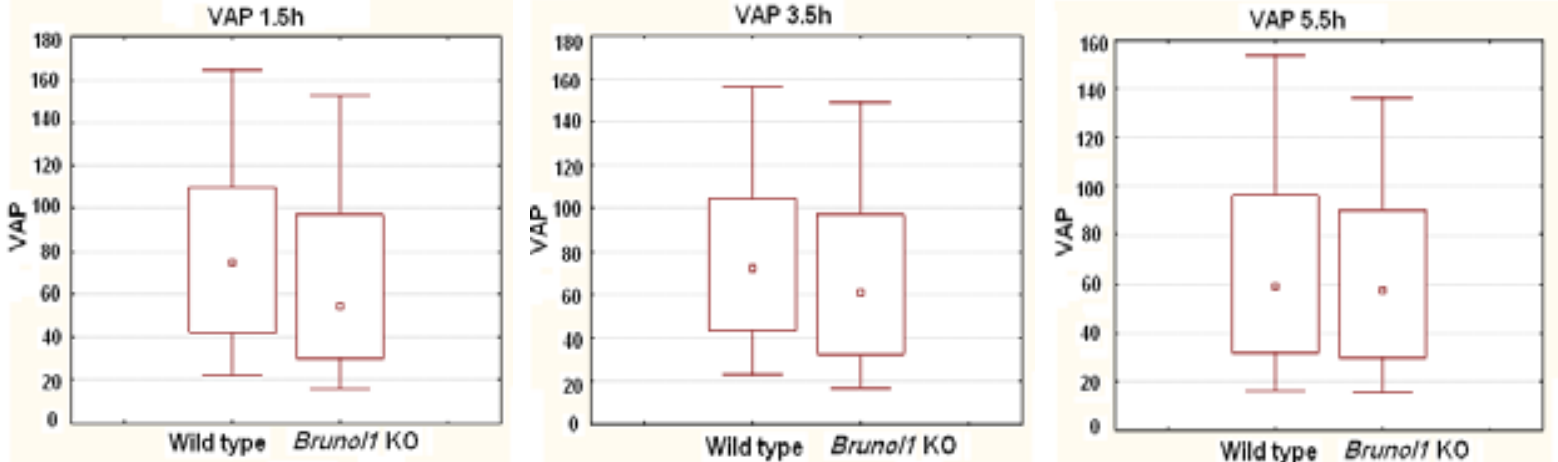

\section{Straight Line Velocity (VSL)}
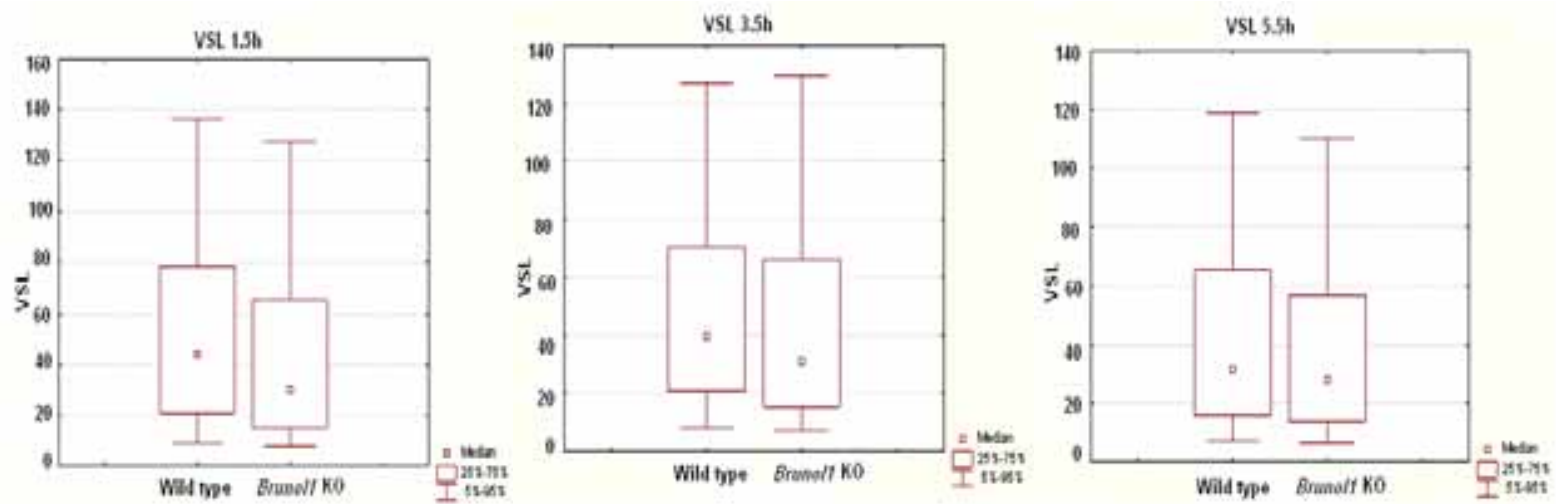

\section{Curvilinear Velocity}
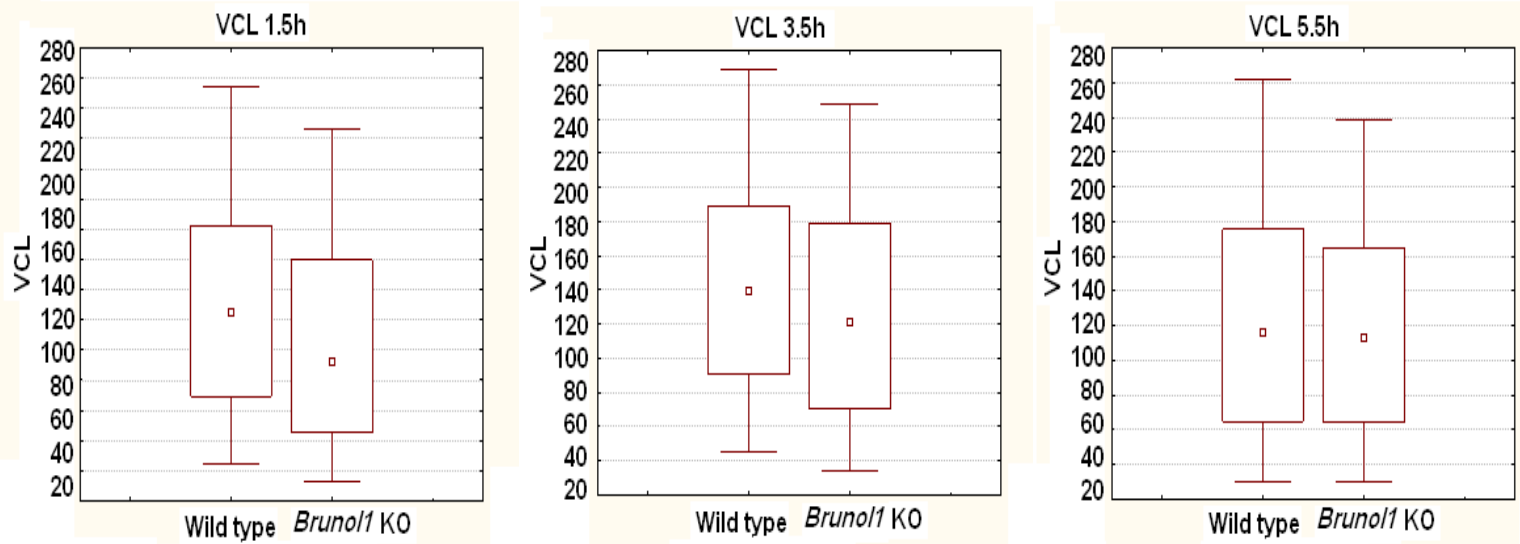


\section{Beat Frequency (BCF)}
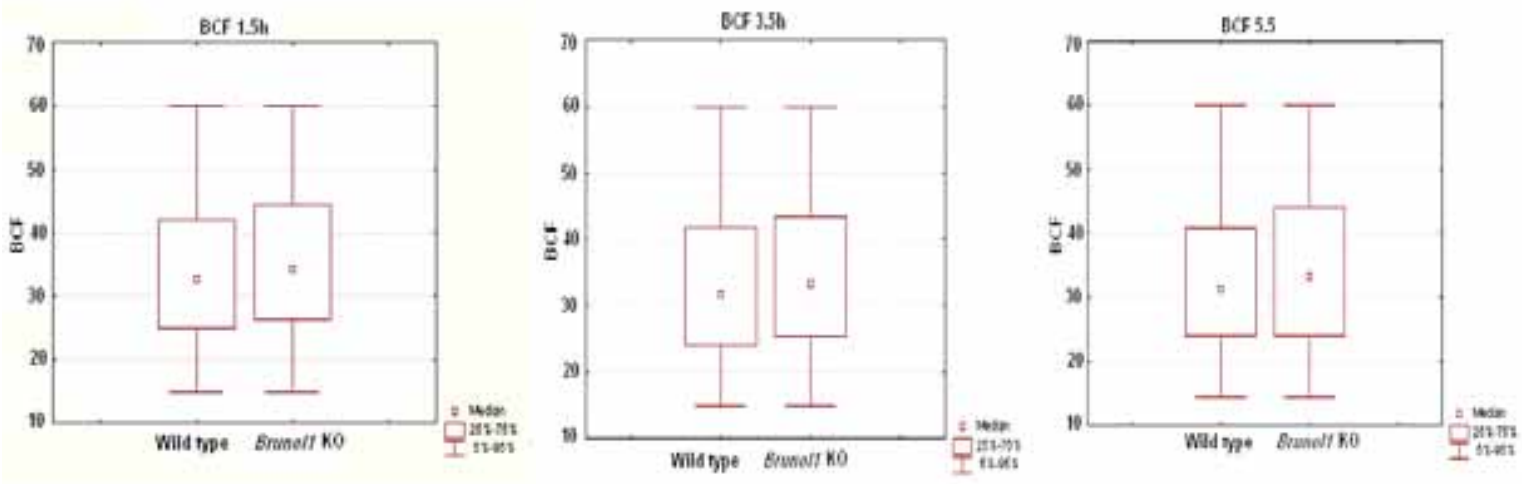

\section{Straight Forward Movement}
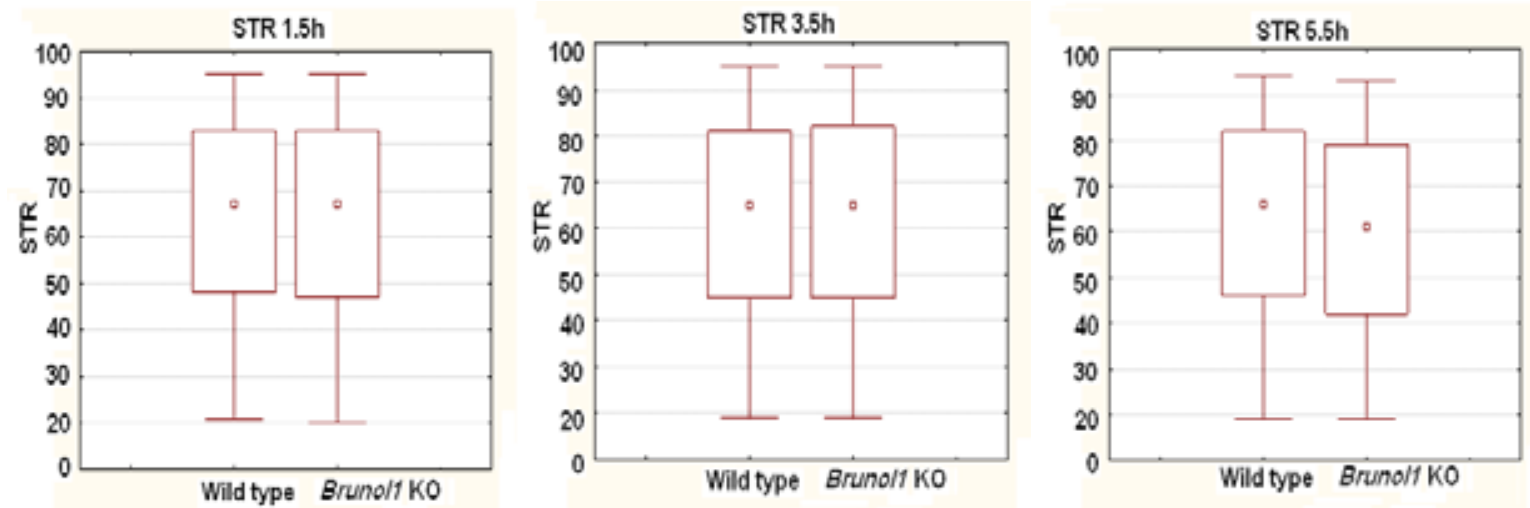

\section{Lateral Head Amplitude}
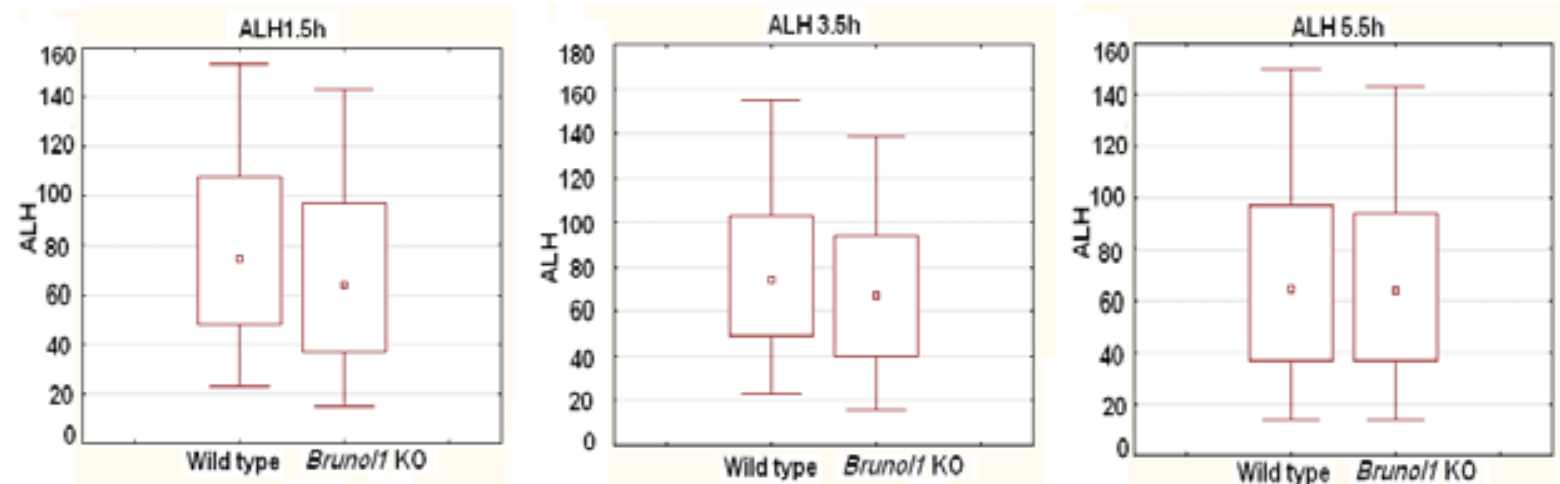
Figure 3.11 Computer assisted analysis of sperm motility. The results of analysis of wild type and knockout spermatozoa on C57 BL/6J x 129/Sv and 129/Sv backgrounds are shown. Sperm velocities (micrometers/second), forward movement (percent), lateral amplitude of the sperm head (micrometers) and beat frequency (hertz) were measured after 1.5, 3.5, and 5.5 hrs. The means and appropriate standard deviations for each parameter are shown. The Brunol1-deficient spermatozoa exhibit statistically significant reduction in all parameters, as compared to wild-type sperm, as it was shown by Mann - Whitney U Test (p< 0.001). Average Path Velocity (VAP), Straight Line Velocity (VSL), Curvilinear Velocity (VCL), Beat Frequency (BCF) and Lateral Head Amplitude (ALH), Straight Forward Movement (STR).

\subsubsection{Histological analysis of Brunol1 deficient males testes}

Testes of Brunol1 ${ }^{--}$and Brunol1 ${ }^{+-}$, males were of normal size and weight. No abnormalities were noticed in their shape. Testes of three Brunol1 ${ }^{-/}$. and two wild type males were fixed in Bouin's solution; paraffin sections were prepared and stained with hematoxylin/eosin, as it was described in section 2.2.14. Histological sections of homozygous male testes on C57 BL/6J x 129/Sv and 129/Sv (Fig 3.12A \& 3.12B) backgrounds revealed normal spermatogenesis; no difference in cellular type or cell number was observed in Brunol1 mutant mice as compared to wild type.

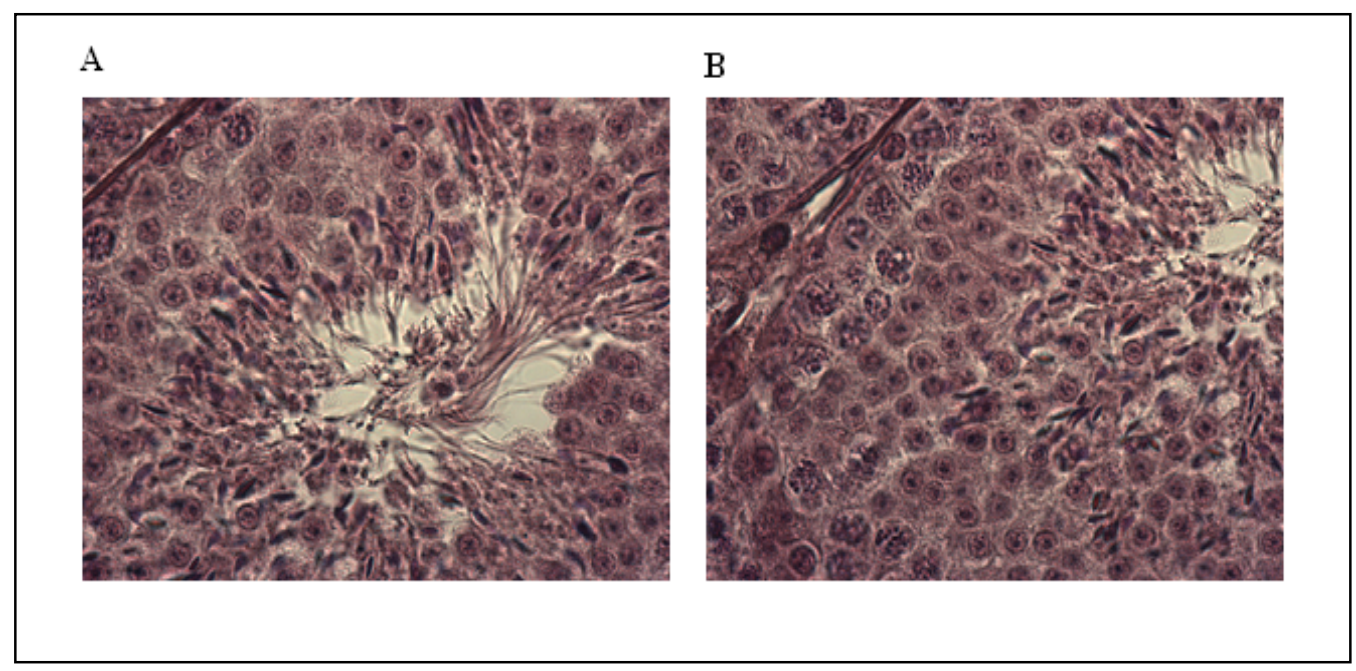


Figure 3.12 Histological sections of testes of Brunol1 mutant males. Paraffin sections of testes of Brunol1 deficient mice reveal normal spermatogenesis. No difference in cellular type or cell number was observed in Brunol1 knockout mice as compared to wild type. Section of testes of Brunol1 deficient male of (A) C 57 Bl/6J x 129/Sv background and (B) 129/Sv background.

\subsubsection{Expression analysis of Brunol6 by Northern blot in Brunol1 deficient mice testis}

In order to determine whether the expression of the Brunol6 (a member of Elav/Bruno family expressed in testis) is increased in testis of the Brunol1 ${ }^{-/}$mice, we performed Northern blot analysis on total testicular RNA isolated from the Brunol1 ${ }^{+/+}$, Brunol1 ${ }^{+/}$and Brunol1 $^{-/}$mice by using 500 bp long 3'UTR of Brunol6 cDNA as probe. Same expression of Brunol6 was detected in all RNA samples and level of expression in the Brunol1 ${ }^{-/}$. was not significantly different from that of the Brunol $1^{+/+}$. mice (Figure.3.13). Integrity of RNA of Northern blot was shown by $28 \mathrm{~S}$ and $18 \mathrm{~S}$ RNA signals on Northern gel picture.

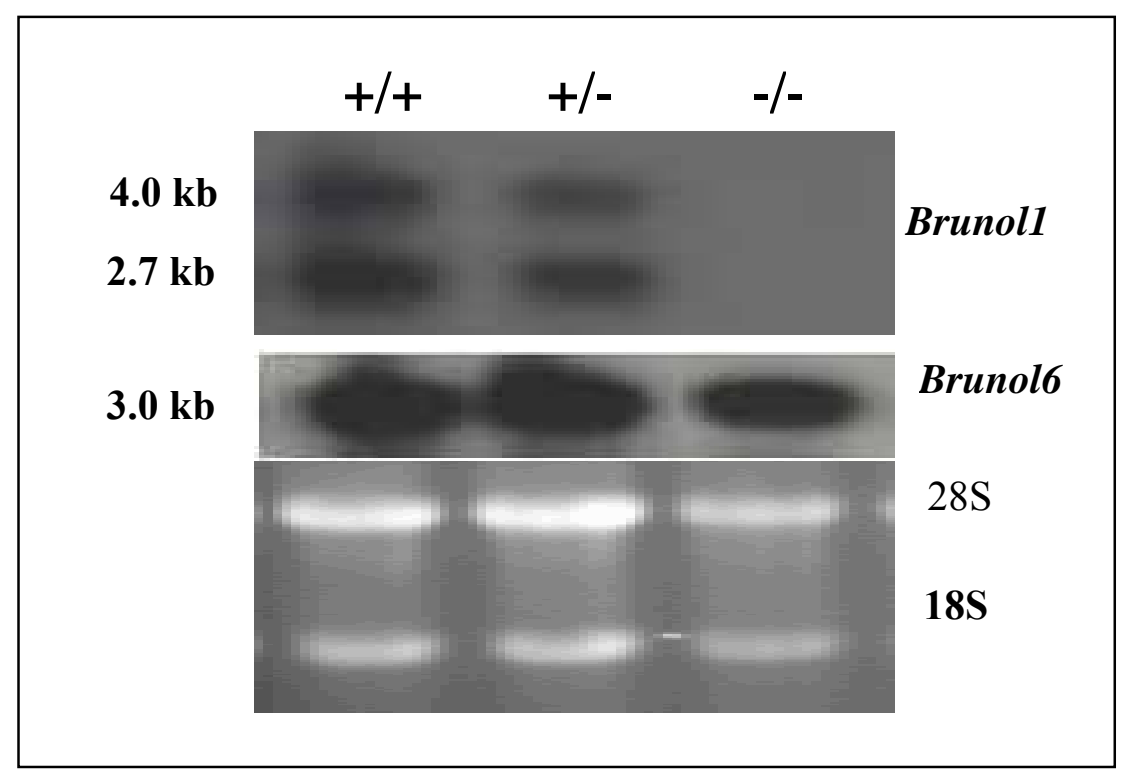

Figure 3.13 Testicular total RNA of the Brunol1 ${ }^{+/+}$, Brunol1 ${ }^{+/}$and Brunol1 ${ }^{-/}$mice was hybridized with ${ }^{32}$ P-labeled 500 bp long 3'UTR of Brunol1 cDNA. Strong expression of Brunol1 can be seen in Brunol1 ${ }^{+/+}$and Brunol1 ${ }^{+/-}$but not in Brunol1 ${ }^{-/-}$ mice. Northern blot analysis with total RNA from testes of Brunol1 ${ }^{+/+}$, Brunol1 ${ }^{+/}$and Brunol1 $^{-/}$mice using 600 bp long 3'UTR of Brunol6 cDNA as a probe showed no 
significant difference in Brunol6 expression between Brunol1 ${ }^{+/+}$, Brunol1 ${ }^{+/}$and Brunol1 ${ }^{-/-}$mice.

\subsubsection{Histological analysis of brain of Brunol1 deficient mice}

Macroscopic inspection of Brunol1 deficient mice brain showed a normal brain size. Histological section of neuronal tissue derived from Brunol1 deficient mice were made by Prof Schwegler at the Institute of Anatomy University of Madeburg. When paraffin embedded brain sagittal sections were stained with crystal violet and observed under microscope, all morphological subdivisions of brain were observed. No difference in cellular type or cell number was observed in Brunol1 mutant mice as compared to wild type. (Fig 3.14)

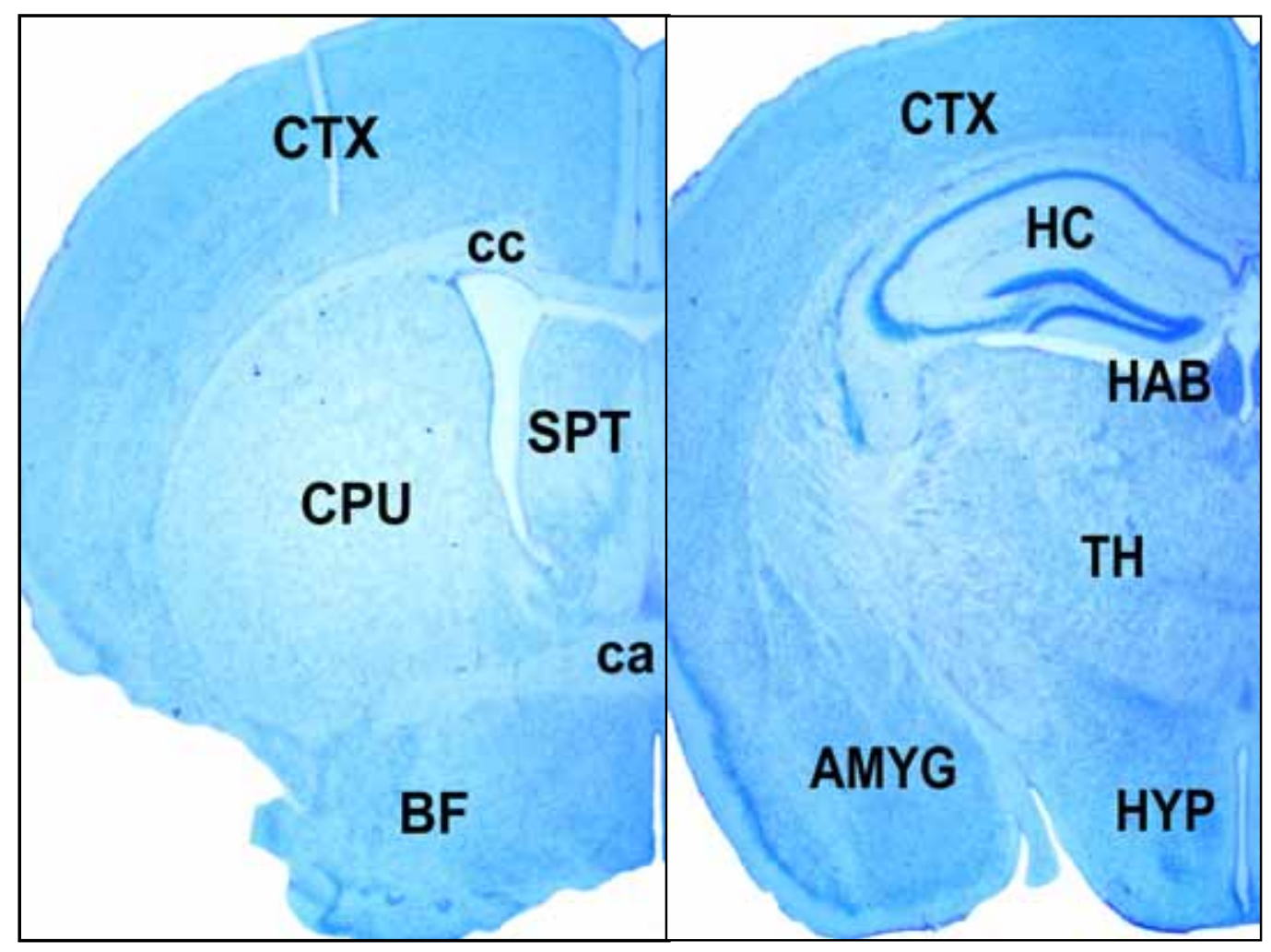

Figure 3.14 Nuclear staining of neuronal tissue derived from Brunol1 deficient mice. Abbrevations are CTX, Cortex; HC, Hippocampus; HAB, Habenula; TH, Thalamus; HYP, Hypothalamus; AMYG, Amygdala; cc, Corpus callosum; CPU, tamen/Nucleus caudatus = Striatum; SPT, Septum; ca, Commissura anterior; BF, Forebrain. 


\subsection{Isolation and characterization of the Brunol4 cDNA}

Brunol4 gene (AC010381) was cloned and characterized by Meins et al. (2002). Murine Brunol4 is a novel gene closely related to elav-type family of genes, which encodes for RNA binding protein. Brunol4 is localised in mouse near the centromere of chromosome 18. The Brunol4 cDNA has 13 exons. It encodes a protein consisting of 495 amino acids. The size of Brunol4 is around $250 \mathrm{~kb}$ due to large size of several introns. Like the other member of elav family, Brunol4 protein also has three RNA recognition motifs (RRM) and one variable motif (Fig.3.15A).

A

\begin{tabular}{|l||l|l|l|}
\hline RRM1 & RRM2 & Divergent Domain & RRM3 \\
\hline
\end{tabular}

B

1 atgtatataaagatggccacgttagcaaacggacaggctgacaacgcgagcctcagtacc

61 aacgggctaggcagcagcccgggcagcgccgggcatatgaacggat taagccacagcccg

121 gggaacccgtcgaccattcccatgaaggaccacgatgccatcaagctgttcattgggcag

181 atcccccgaaacctggatgagaaggacctcaagccctcttcgaggagttcggcaagatc

241 tacgagcttacggttctgaaggacaggttcacaggcatgcacaaaggctgcgctttcctc

301 acctactgcgagcgtgagtcagcgctgaaggcccagagcgcgctgcacgagcagaagacc

361 ctgccogggatgaaccggccgatccaggtgaagcctgcggacagcgagagccgaggaggt

421 agtagctgcctgcgccagccccttcacaagatagaaaactcttcgtgggtatgctcaac

481 aagcaacaatctgaggacgacgtgcgccgcctcttcgaggccttcgggaacatcgaggag

541 tgcactatcctgcgcgggccggacggcaacagcaaggggtgcgcctttgtgaagtactcc

601 tcccatgccgaggcacaagccgccattaacgctctacatgcagccagaccatgcctggaa

661 gcctcctccagcctggtggtcaagtt tgcagacactgacaaggagcgcacaatgcgacgg

721 atgcagcagatggctggccagatgggcatgttcaaccccatggccatcccttcggagcc

781 tatggcgcctatgctcaggcactgatgcagcagcaagcagccctcatggcatcggtcgcg

841 caaggaggctacctgaatcccatggctgccttcgctgccgccaaatgcagcagatggcg

901 gccctcaacatgaatggcctggcagccgcacctatgaccccaacctcaggtggcagcacc

961 cctccaggcatcactgcaccagctgtgcctagcatcccatccccattggggtgaacggc

1021 ttcacgggcctccccctcaggccaatgggcagcctgctgcggaagctgtgtt tgccaat

1081 ggcattcaccctacccagcacagagccccaccgcagccgacccctgcagcaggcctac

1141 gctggagtgcagcagtatgcaggacctgcctaccctgctgcctatggtcagattagccag

1201 gcctttcctcagccaccgccaatgat tccccagcaacagagagaagggcccgagggctgt

1261 aacctgctcatctaccatctgcccaggagtttggggacgctgagctgatgcagatgttc 
1321 ctccetttcggcttcgtgagcttcgacaaccoggccagcgcacagaccgccatccaggcc

1381 atgaacggcttccagataggcatgaagaggctcaaggtgcagctgaagcggcccaaagac

1441 gccaatcgccogtactga

Figure 3.15 (A) Schematic representation of Brunol4 protein domain. (B) Nucleotide sequence (from NCBI) of Brunol4 cDNA. ATG codon, indicating start of translation and TGA terminating codon are bold and coloured blue.

\subsubsection{Expression analysis of mouse Brunol4 gene}

\subsubsection{RT PCR analysis of Brunol4 during development}

To examine the expression of Brunol4 during development, RT-PCR analysis was performed with RNA range from embryonic stages including preimplantation stages $(2,4$ and 8 cell stages) (Fig 3.16 A). Brunol4 expression was detected as early as two cell stage and continued up to blastocysts stage. In postimplantation stages, Brunol4 expression is detected as early as 7.5 days post coitum (dpc) and continues to express at all the stages of embryonic development (Fig. 3.16 B).

\subsubsection{RT PCR analysis of Brunol4 in adult mouse}

To analyse the expression of Brunol4 in adult mouse at the RNA level, total RNA was isolated from different adult mouse tissues including brain, eye, muscle, kidney, liver, heart, lung, spleen, testis and ovary. By RT-PCR analysis, a Brunol4 transcript could be detected from samples of brain and ovary, Integrity of the RNA used for RT-PCR. was proved by amplification of the Gapdh transcript. (Fig. 3.16 C).

$\mathbf{A}$

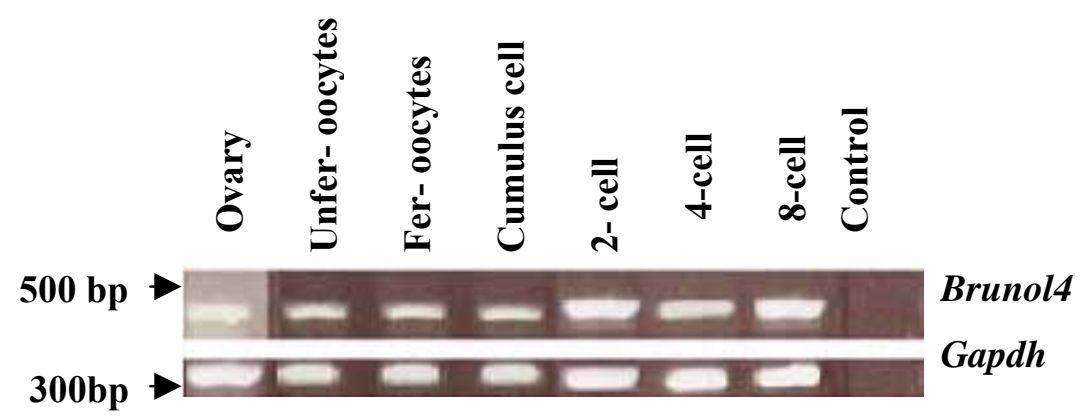



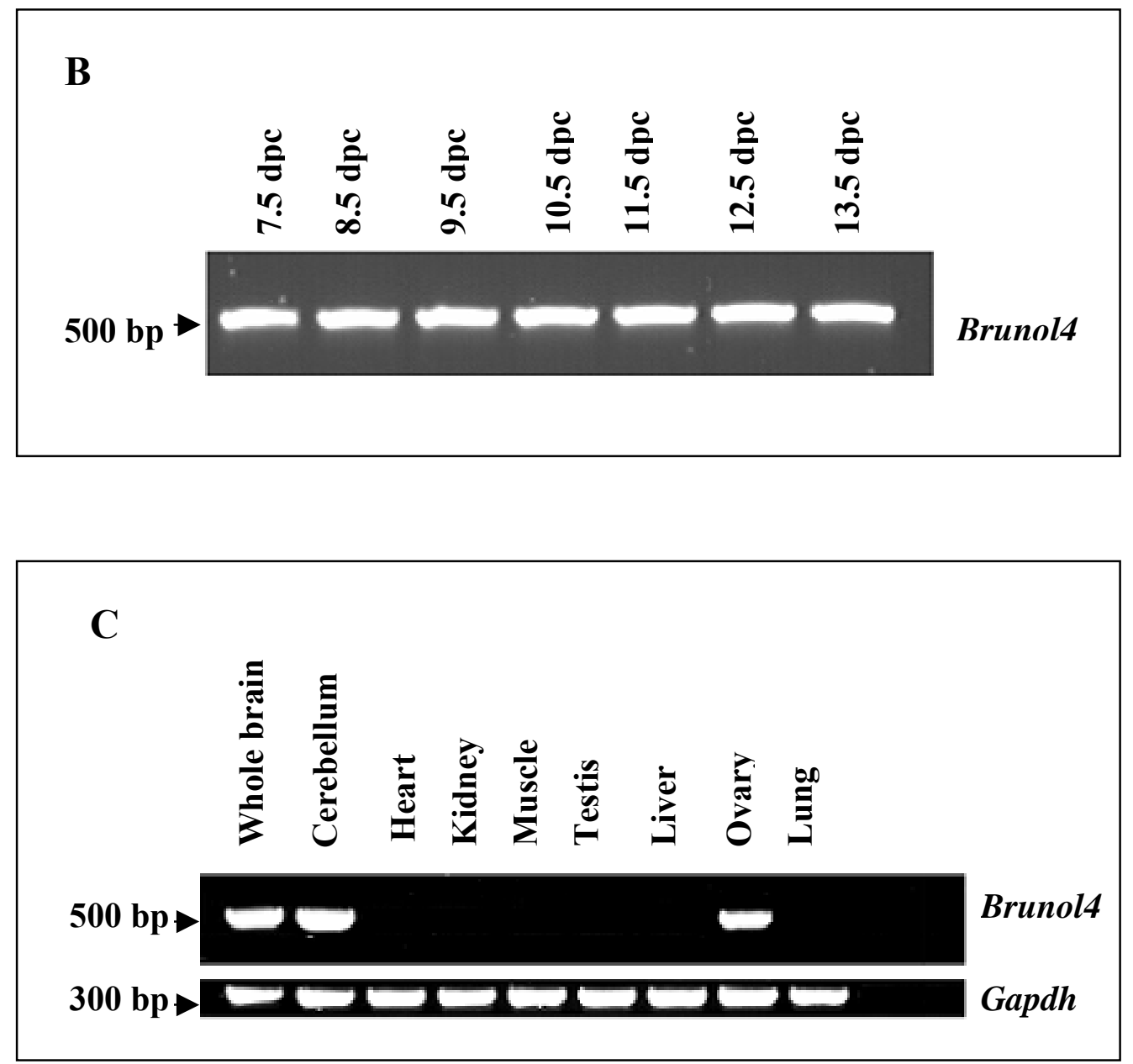

Figure 3.16 RT-PCR expression analysis of Brunol4 during development by using Brunol4F and Brunol4R specific primers (A) Preimplantation stages of development. (B) Postimplantation stages of development. (C) Different adult tissues. Expression of Brunol4 is restricted to brain and ovary. Gapdh served as a control.

\subsubsection{Northern Blot analysis of Brunol4 in adult mouse}

To determine the expression of Brunol4 at the Northern blot level, total RNA from heart, lung, muscle, testis, liver, kidney, ovary, cerebellum and whole brain was size fractioned in a 1\% agarose/MOPS gel containing 5.5\% formaldehyde and blotted onto Hybond-XL membrane. The Northern blot was hybridised with a ${ }^{32} \mathrm{P}$-labelled 500-bp fragment from the $3^{\prime}$-end of the murine Brunol4 cDNA probe, which detected approximately $3.0 \mathrm{~kb}$ strong hybridisation signal in whole brain sample and cerebellum. 
No signal was visible in other adult tissues tested. Integrity of RNA was checked by hybridization with HEF probe (Fig. 3.17).

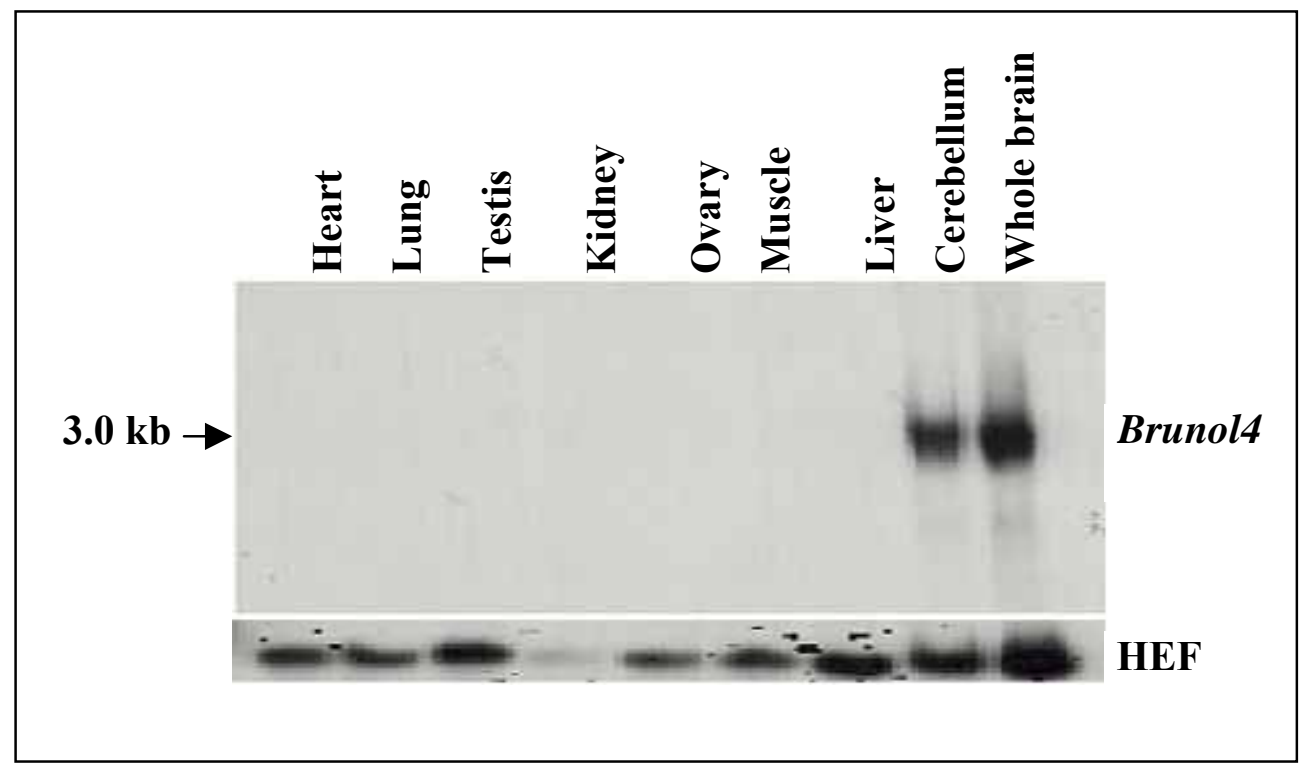

Figure 3.17 Northern Blot analysis of Brunol4 in different tissues, using 3' UTR specific probe. Expression of Brunol4 is restricted to the brain.

\subsubsection{Targeted inactivation of mouse Brunol4 gene}

One of the best ways to elucidate gene function is the generation of a knockout animal model. For this purpose, Brunol4 knockout mouse was generated in this study. Analysis of the phenotype of mice with targeted disruption of Brunol4 gene could help in understanding the role of the Brunol4 gene during development.

\subsubsection{Generation of the Brunol4 knockout construct}

A cosmid clone (MPMGc121D15262Q2) containing the 5' region of Brunol4 gene was isolated and characterised by restriction analyses and sequencing reactions (Meins et al., 2002). In order to generate the Brunol4 targeting vector, a region of 800 bp of the Brunol4 gene containing part of exon1 and intron1 was replaced by GFP and Neomycin phosphotransferase gene cassette under the control of phosphoglycerate kinase promoter. In this construct, neomycin was used as marker for positive selection while two copies of thymidine kinase from Herpes simplex virus were used as a negative selection marker (Fig $3.18)$. 


\subsubsection{Subcloning of 5' wing of the Brunol4 knockout construct into the pBlueScriptII SK vector}

The clones that were designated as positive during cosmid library screening were digested with KpnI and SalI enzyme. A $3.8 \mathrm{~kb}$ KpnI and SalI fragment containing the 5'flanking region with part of exon1 and intron1 of the Brunol4 gene (Figure 3.18) was isolated from the cosmid clone (MPMGc121D15262Q2) and purified from agarose gel. This fragment was subcloned into pBlueScript SK vector using the KpnI and SalI sites. To tag the EGFP open reading frame with 5'wing of Brunol4 knockout construct, primers were designed having XhoI restriction site at the 3'end. The complete ORF of EGFP was amplified and the fully sequenced EGFP PCR product was cloned in to pBlueScriptII SK vector by using the XhoI. Finally the $5^{\prime}$ fragment fused with EGFP was digested with XhoI and SalI from pBlueScriptII SK+ vector and was cloned into pTKNeo vector.

\subsubsection{Subcloning of 3' wing of the Brunol4 knockout construct into the pBlueScriptII SK vector}

For the generation of 3' wing of the construct, a $5.3 \mathrm{~kb} \mathrm{XbaI} \mathrm{fragment} \mathrm{containing} \mathrm{a} \mathrm{part}$ of intron1 of the Brunol4 gene (Figure 3.18) was isolated from the cosmid clone (MPMGc121D15262Q2) and purified from the agarose gel. This fragment was subcloned into pBlueScript SK vector using the XbaI site. Then the $5.3 \mathrm{~kb}$ fragment was again extracted from pBlueScript vector by SpeI and NotI enzyme and cloned into the pTKNeo vector using the same sites. In order to check positive orientation of both wings in the vector, GFP-1374-F, Bru4-3'GenomicR, Neo-R and Neo-F primers, specific for the construct, were used for sequencing. The construct was linearized at the PvuI site present at the backbone of pTKNeo vector and in ampicillin cassette.

\subsubsection{Generation of the 5 ' external probe}

The 5' probe for screening of ES cells was generated to distinguish between wild type and recombinant clones. For this purpose, a fragment of 900 bp was amplified by PCR, using primers Bru-4-Ext-Probe-F and Bru-4-Ext-Probe-R.The PCR fragment was cloned in pGEM T-Easy vector and sequenced, then digested with EcoRI restriction enzyme. This external probe recognizes a $7.6 \mathrm{~kb}$ fragment in case of wild type and a $6.0 \mathrm{~kb}$ fragment in case of recombinant clone in Southern blot hybridization after digestion of genomic DNA with AfIII enzyme (Fig 3.18B). 
A
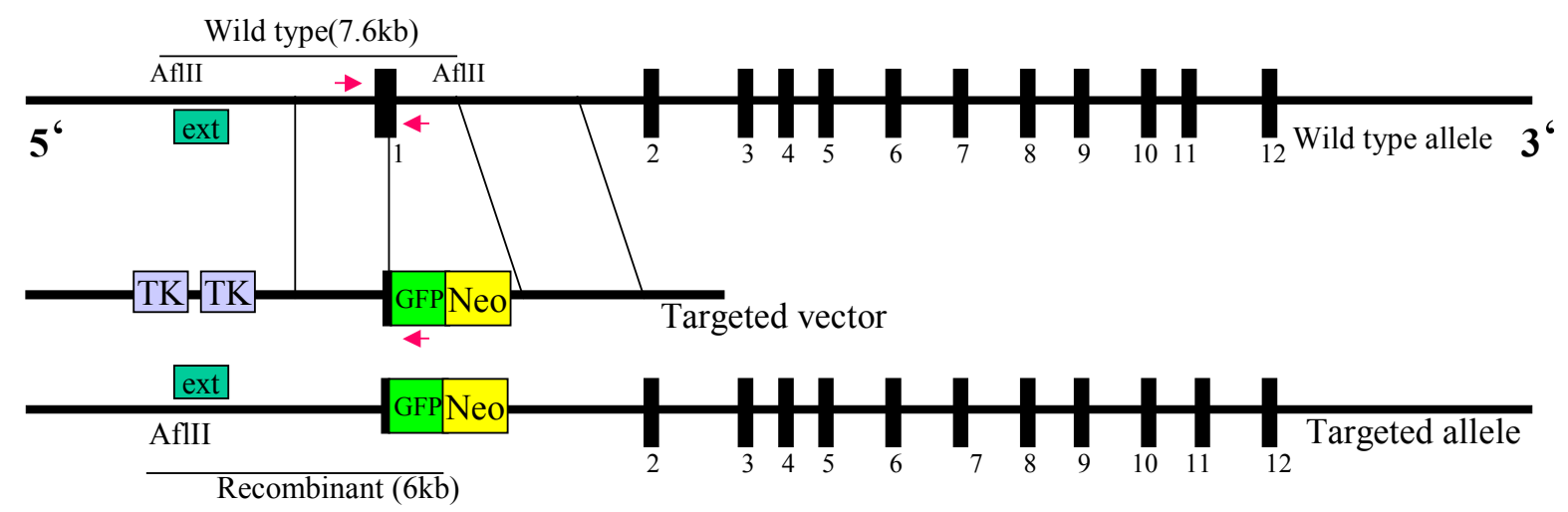

B

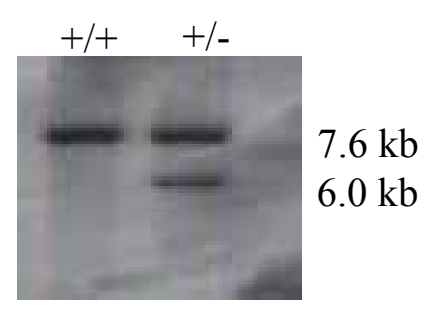

C

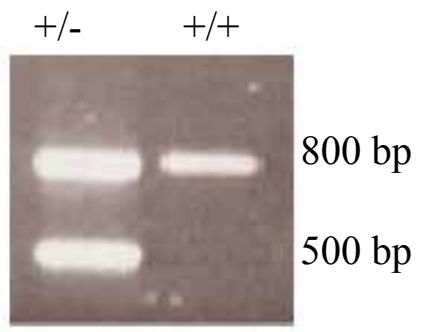

Figure 3.18 Mouse Brunol4 gene and targeting vector. (A) Upon homologous recombination of the 5'and 3'arm of vector with the Brunol4 locus (top), a part of exon 1 is replaced by the coding sequence of GFP and Neo cassette. (B) Southern blot analysis of genomic DNA isolated from recombinanat ES cell upon digestion with AfIII. Wild type (+/+) allele gives rise to a 7.6-kb fragment, while the digested mutant allele (+/-) generates 7.6-kb and 6-kb fragments detected with a 5'external probe. (C) PCR genotyping of wild type $(800 \mathrm{bp})$ and heterozygous $(800 \mathrm{bp}+500 \mathrm{bp})$ mutant mice. Red arrows show the location of the primers for genotyping.

\subsubsection{Electroporation of the ES cells and screening of ES cells for homologous recombination}

Brunol4 targeting vector was linearized with PvuI enzyme and $50 \mu \mathrm{g}$ of purified DNA was electroporated into RI embryonic stem cells, as it was described in section 2.2.19.1. Cells were plated on feeder layer and after 10 days of selection 98 clones resistant for neomycin 
were selected and cultured on 24 well plates. Genomic DNA was isolated from ES cells, as it was described in section 2.2.1.4, and used for Southern blot hybridization. DNA from each clone was digested with Afll II enzyme, electrophoresed and blotted onto Hybond-XL membrane. Blots were then hybridized with radioactively labelled 5'external probe. Two bands were recognized in case of homologous recombination, $7.6 \mathrm{~kb}$ wild type allele and $6.0 \mathrm{~kb}$ recombinant allele. When no recombination has occurred or non-homologous recombination had taken place, only wild type band could be detected (Fig.3.18 B). Total 90 clones were screened, out of 400 clones only one of them was recombinant, these results were confirmed, using GFP probe, which detected $6.0 \mathrm{~kb}$ expected recombinant band. Clone No. 55, rehybridized with external probe again and was chosen for blastocyst injection.

\subsubsection{Generation of chimeric mice}

The recombinant ES cells were injected into 3.5 dpc blastocysts derived from C57BL/6J mice. The blastocysts were implanted into the pseudopregnant CD1 mice to generate the chimeric mice. Total 4 chimeras were obtained by three independent injections of recombinant ES clones. The chimeras were scored according to the coat color (in percentage), $5 \%, 2 \times 15 \%$ and $25 \%$. All chimeras were bred with C57BL/6J mice, to obtain F1 animals in C57BL/6J background. Germ line transmission was detectable only by one $25 \%$ chimera after one and half month of breeding. The germ line transmission of the mutant allele was verified by genomic PCR by using Bruno4-Geno-F, Bru-4 Del-R and GFP-1405-R primers on DNA isolated from tail biopsies of the offspring (Fig 3.18 C).

\subsubsection{Generation and analysis of Brunol4 knock out mice}

F1 heterozygotes were intercrossed to produce the homozygous offspring. No change in the sex ratio of Brunol4 mice for the offspring of the heterozygous matings was noted in C57BL/6J background. Surprisingly, no homozygous (Brunol4 ${ }^{-/}$) mice were notified out of 255 offspring, derived from the heterozygous intercrosses. In addition, there seemed to be no reduction in litter size (7.5) in comparison to matings of wildtype animals. The ratio of wildtype to heterozygotes was approximately 1:3 and among the 255 live-born offspring, 90 were wildtype and 165 were heterozygous mice in the C57BL/6J x129/Sv genetic background (Table 3.6) 


\begin{tabular}{|c|c|c|}
\hline $\begin{array}{c}\text { C57BL/6J } x \\
129 / \mathrm{Sv}\end{array}$ & Female & Male \\
\hline \multirow[t]{2}{*}{ WT } & $49=54.5 \%$ & $41=45.5 \%$ \\
\hline & \multicolumn{2}{|c|}{$90=35 \%$} \\
\hline \multirow[t]{2}{*}{ HE } & $94=56 \%$ & $71=43 \%$ \\
\hline & \multicolumn{2}{|c|}{$165=65 \%$} \\
\hline \multirow[t]{3}{*}{ HO } & $00=00 \%$ & $00=00 \%$ \\
\hline & \multicolumn{2}{|c|}{$00=00 \%$} \\
\hline & $143=56 \%$ & $112=45 \%$ \\
\hline
\end{tabular}

Table 3.6 Result of the genotype analysis of the $\mathrm{F} 2$ generation in $\mathrm{C57BL} / 6 \mathrm{~J} \mathrm{x}$ 129/Sv background. Abbreviations are WT (wild type), HE (heterozygous) and HO (homozygous).

\subsubsection{Determination of the stage of embryonic death of Brunol4 homozygous mice}

While Brunol4 heterozygous mice were apparently healthy and fertile, no Brunol4 homozygous mice were identified. This result revealed that homozygous embryos might be lethal. To determine the stage when development of homozygous embryos is arrested, a detailed analysis of embryos at different stages of development was done including pre- and post-implantation stages. To analyse the post-implantation stages of embryonic death, Brunol4+/- mice were mated and the pregnant mice were sacrificed at $13.5 \mathrm{dpc}$. Among 31 embryos obtained, 10 were wild type and 21 were Brunol4 $^{+/-}$, but no Brunol4 ${ }^{-/-}$mice were obtained: We also examined 10.5 and $8.5 \mathrm{dpc}$ but none of embryo was homozygous (Table 3.7). To examine the embryos at 2-cell (E1.5) stage, 4-cell (E2.5) stage, 8-cell (E3.0) stage and blastocyst stage (E3.5), Brunol4 ${ }^{+/}$. mice were mated and the embryos were collected at two-cell stage (E1.5). To avoid any maternal contamination, embryos were cultured with the M16 medium (Sigma) to 4-cell stage (E2.5) and 8-cell stage (E3.0). From individual 2, 4 and 8-cell stage embryos, zona pellucida was dissolved and polar bodies were removed, 
before genotyping (Figure 3.19). Embryos were individually photographed and transferred directly to PCR cups and subjected to PCR. Genotyping results of embryos showed wild type and heterozygous embryos but none of them was homozygous (Table 3.7). Further we analysed one-cell stage embryos. To genotype the embryos at one cell stage, individual 1cell embryos were microscopically analysed to differentiate between fertilized and unfertilised embryos. From individual one-cell embryos, zona pellucida was dissolved and polar bodies were removed, before genotyping (Figure 3.19). We genotyped 61 one-cell stage embryos, all of them were heterozygous (Table 3.7) (Figure 3.20). To genotype the blastocysts, embryos at E3.5 were flushed out from the uteri of Brunol4 ${ }^{+/-}$. female mice and mated with Brunol4 ${ }^{+/}$. males. To avoid any maternal contamination, blastocysts were cultured for six days in ES cell medium containing leukaemia inhibitory factor (LIF). Under these conditions, embryos hatched from their zona pellucida and attached to the gelatine-coated dishes. All the blastocysts were morphologically normal and indistinguishable from wild type (Figure 3.21). Among the 52 blastocysts genotyped, 15 were wild type and 37 were heterozygous (Table.3.7)

\begin{tabular}{|l|c|c|c|}
\hline $\begin{array}{c}\text { Embryonic development } \\
\text { stage }\end{array}$ & \multicolumn{3}{|c|}{$\begin{array}{c}\text { Genotyping } \\
+/-\end{array}$} \\
\hline $13.5 \mathrm{dpc}$ & 10 & 21 & $-/-$ \\
$10.5 \mathrm{dpc}$ & 07 & 20 & 00 \\
$8.5 \mathrm{dpc}$ & 15 & 24 & 00 \\
E 3.5 (Blastocysts) & 15 & 37 & 00 \\
8-cell stage & 11 & 37 & 00 \\
4-cell stage & 15 & 77 & 00 \\
2 cell stage & 37 & 151 & 00 \\
1 cell stage & 00 & 61 & 00 \\
& & & 00 \\
\hline
\end{tabular}

Table 3.7 Genotyping of embryos obtained from intercroses between $\mathrm{Brunol}^{+/-}$mice. Embryos were examined by PCR analysis at different stages of embryonic development, 13.5, 10.5, 8.5, $3.5 \mathrm{dpc}, 8$-cell stage, 4-cell stage, 2-cell stage and 1-cell stage. Wild type (+/+) and heterozygous (+/-) embryos were obtained from Brunol4+/intercroses but none of them was homozygous (-/-) 
A

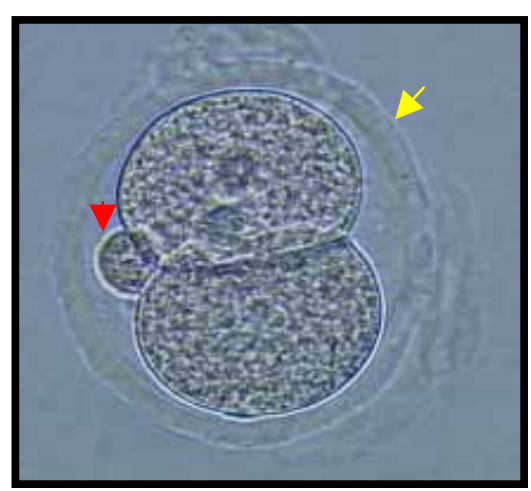

Removal of zona pellucida with the treatment of hyaluronidase

B

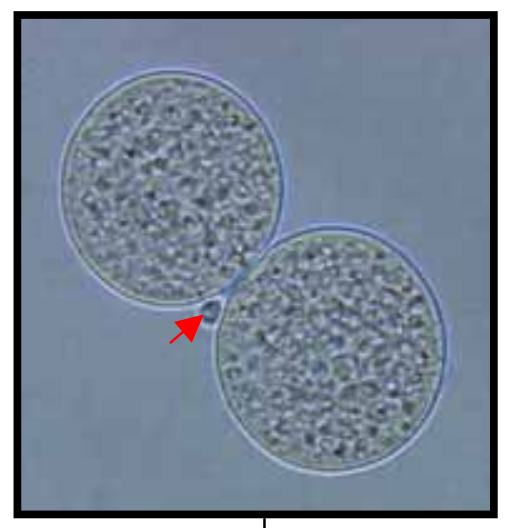

Removal of polar body with the treatment of Acutase

C

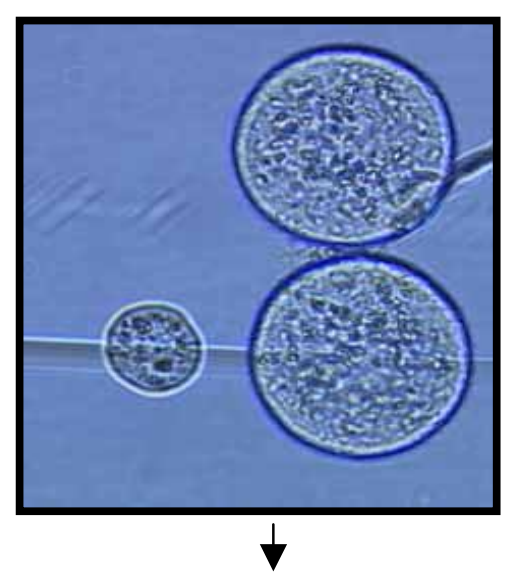

D
$+/-$
$+/+$
$+/-$

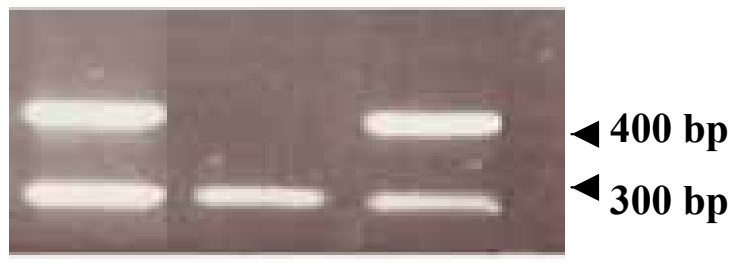


Figure 3.19 Genotyping of two-cell stage embryos. (A) 2-cell stage embryo with polar body and zona pellucida. (B) 2-cell stage embryo after removal of zona pellucida. (C) 2cell stage embryo after removal of polar body. (D) PCR results of 2-cell stage embryos genotyping, wild type (400bp) and heterozygous $(400 \mathrm{bp}+300 \mathrm{bp})$. Red arrows represents the polar body, yellow arrow represents the zona pellucida.

A

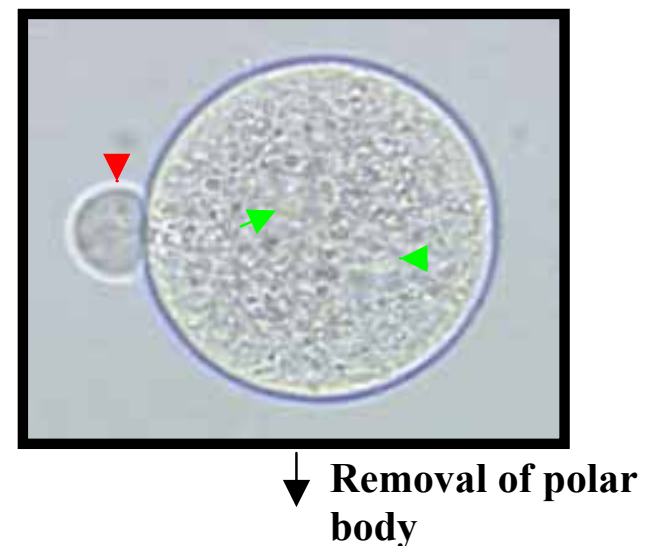

B

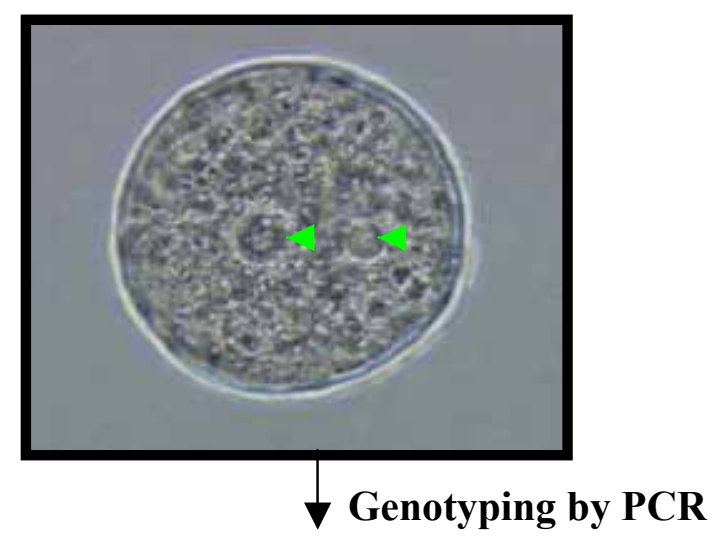

C

+/- +/- +/- +/- +/- +/- +/- +/- +/-

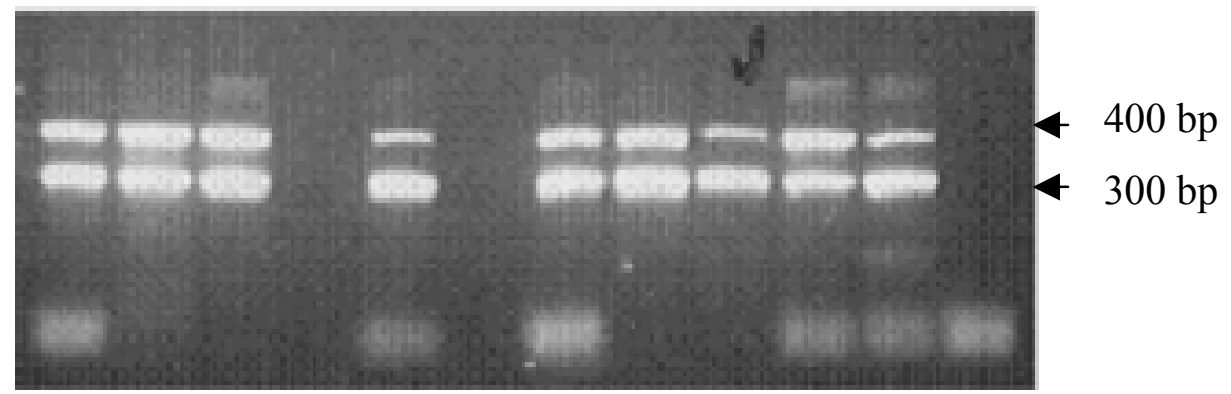


Figure 3.20 Genotyping of one-cell stage embryos. (A) One-cell stage embryo with maternal and paternal nucleus. (B) One-cell stage embryo after removal of polar body. (C) PCR results of one-cell stage embryos genotyping. Green arrows represents the maternal and paternal nuclei, red arrow represents the polar body.
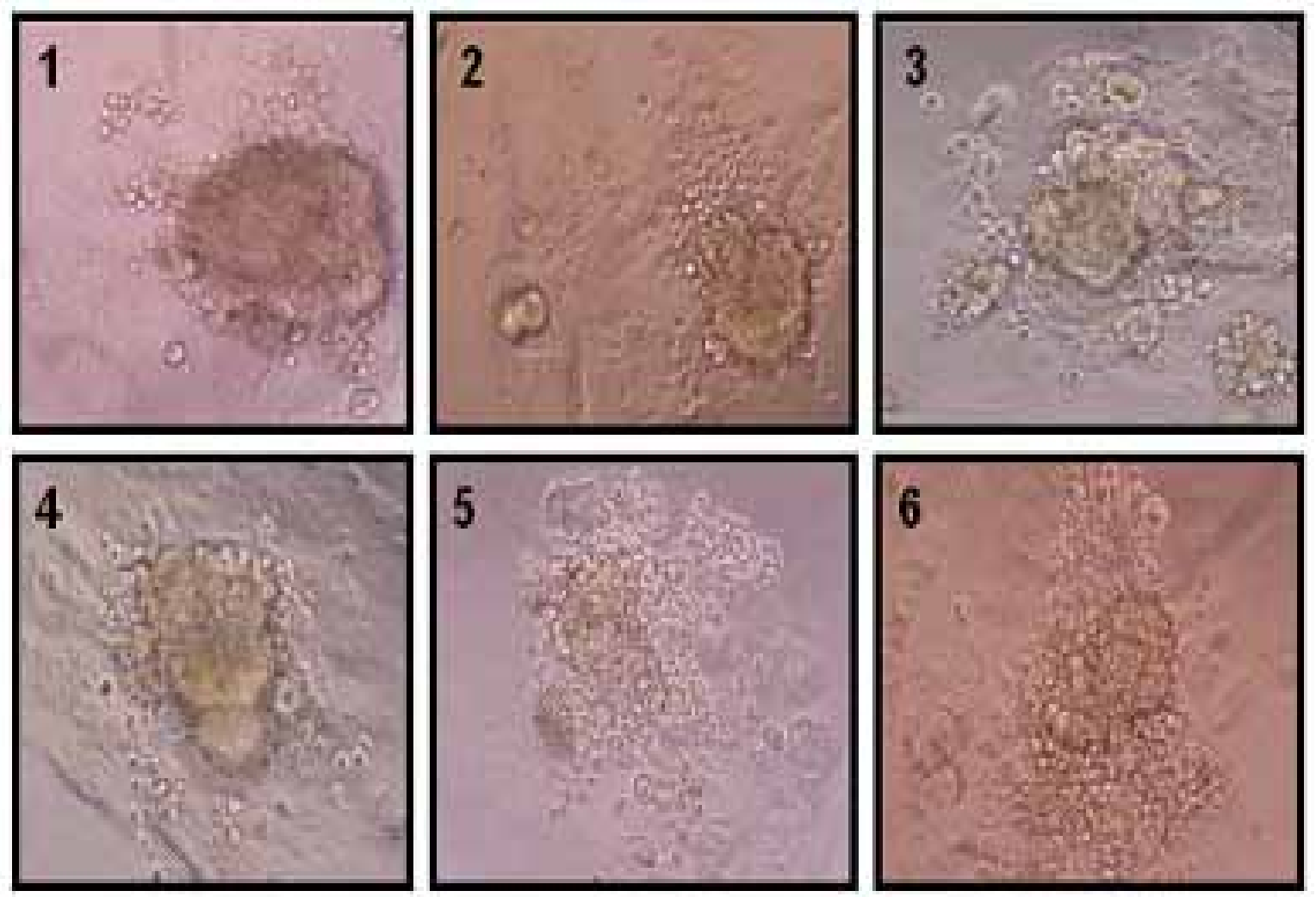

Figure 3.21 In vitro outgrowth of cultured blastocyst $(3.5+6)$. Isolated blastocysts were grown in vitro. Representative heterozygous blastocysts $(1,2,3,4,5)$ and wild type blastocyst (6) is shown.

\subsubsection{Murine Brunol4 is present in more than one copy}

Embryological analysis of Brunol4 ${ }^{+/-}$mating showed that there were wild type and heterozygous embryos but homozygous embryos were selectively missing even at one cell stage (Table 3.7). This result suggested that there might be two copies/duplication of Brunol4 gene. Brunol4 homozygous mutant was not identified by genotyping (PCR and Southern Blot). Then, 10 Brunol4 heterozygous mice were bred with wild type and four pairs gave all heterozygous offspring (Table 3.8). These results clearly indicated that there are in fact Brunol4 homozygous mice among heterozygous but they could not be identified 
by genotyping. Further, these homozygous mice were analysed by Northern Blot analysis but there was no reduction in Brunol4 transcript compared to wild type (Figure 3.22) Taken together these observations suggest that there are two copies of Brunol4 gene and the one, which is not transcribed, was deleted.

\begin{tabular}{|c|c|c|}
\hline \multicolumn{2}{|c|}{ Parents } & \multirow{2}{*}{$\begin{array}{c}\text { Offspring } \\
\text { HE \& WT }\end{array}$} \\
\hline $36{ }^{\lambda}$ & WT ㅇ & \\
\hline $37{ }^{\lambda}$ & WT $q$ & HE \& WT \\
\hline $39{ }^{\lambda}$ & WT $q$ & $\mathrm{HE}$ \\
\hline $92 \AA$ & WT q & HE \& WT \\
\hline $93 \widehat{\partial}$ & WT $q$ & HE \& WT \\
\hline $45 q$ & WT $\hat{\sigma}$ & HE \& WT \\
\hline $49 q$ & WT $\sigma^{\lambda}$ & $\mathrm{HE}$ \\
\hline $53 q$ & WT $\hat{0}$ & HE \& WT \\
\hline $77 q$ & WT $\widehat{0}$ & $\mathrm{HE}$ \\
\hline 83 웅 & WT $\hat{0}$ & $\mathrm{HE}$ \\
\hline
\end{tabular}

Table 3.8. Result of breeding of Brunol4 ${ }^{+-}$with wild type. Ten $\mathrm{Brunol}^{+/}$mice $(36 \overbrace{}^{\lambda}$,

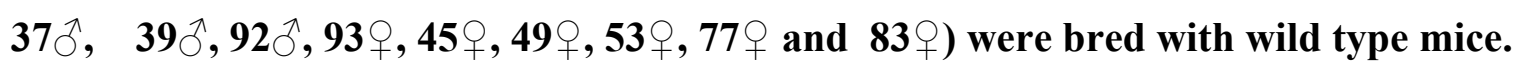
Out of 10 breeding pairs, 4 pairs $(93 \hat{\diamond}, 49 \hat{\diamond}, 53 \propto$ and $77+$ ) gave only heterozygous offspring. 


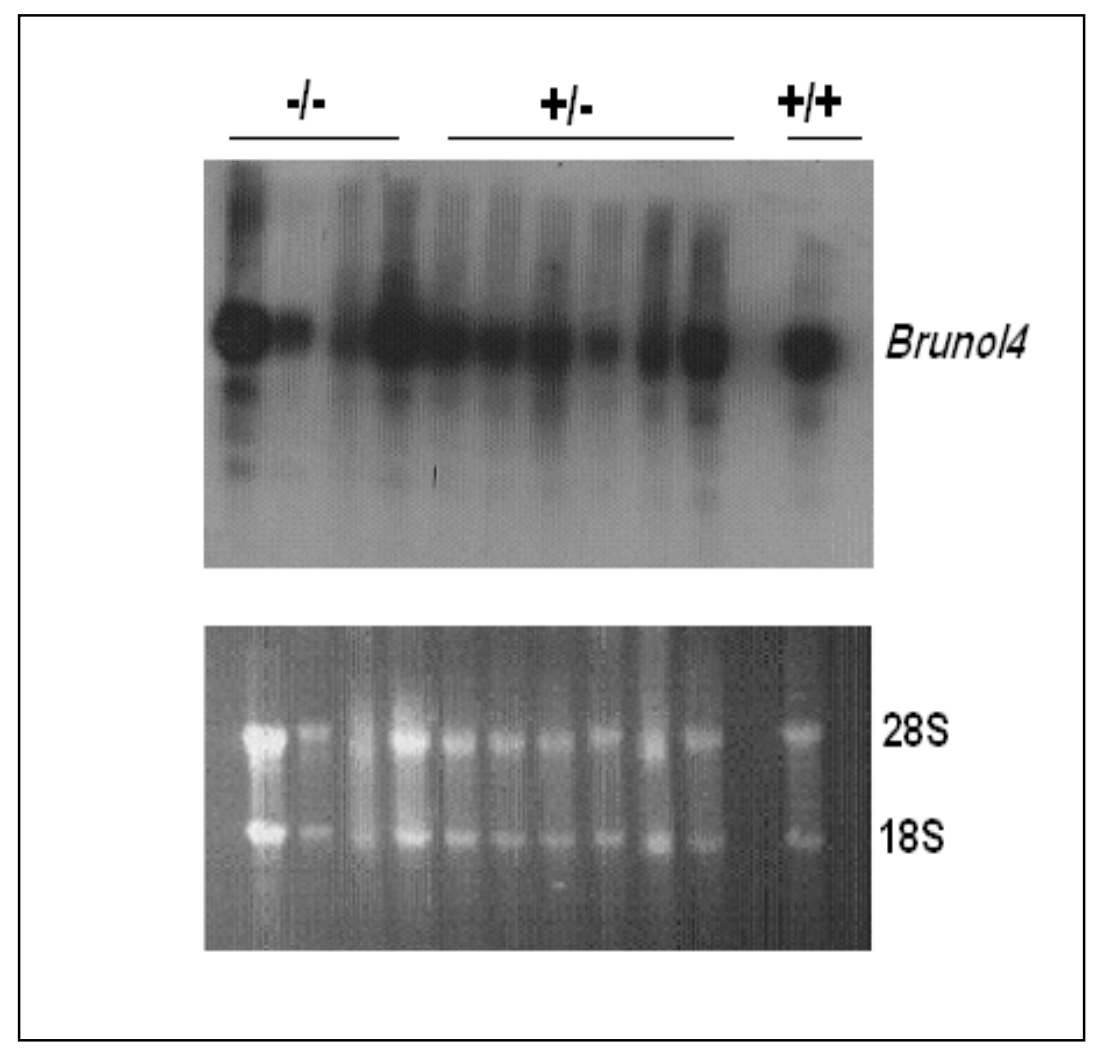

Figure 3.22 Northern blot analysis with total RNA of brain of different Brunol4 heterozygous, so-called homozygous and wild type mice by using $3^{\prime}$ UTR specific probe. There was no reduction of Brunol4 transcript in Brunol4 homozygous and heterozygous as compared to wild type mice. 


\subsection{Isolation of the Brunol6 cDNA}

Brunol6 gene (accession number BC052406) is a novel member of Elav/ Bruno family, encoding RNA binding protein. To obtain the actual coding region of Brunol6, full-length Brunol6 ORF was amplified from mouse brain cDNA by PCR using the primers that contained the predicted start and stop codon. Brunol6 has 13 exons. It encodes a protein consisting of 460 amino acids. Brunol6 is localised on mouse chromosome 9. As the other Brunol family members, the domain structure of Brunol6 is also the same, having three RNA recognition motifs (RRMs) and a divergent domain (linker) separating RRM2 and RRM3 (Fig 3.23 A)

$\mathbf{A}$

\begin{tabular}{l||l|l|l} 
RRM1 & RRM2 & Divergent Dom ain & RRM3 \\
\hline
\end{tabular}

B

1 atggccgcggcgcetggagggtctgcgccgccogccggccccagc $\begin{array}{lllllllllllllll}M & A & A & A & P & G & G & S & A & P & P & A & G & P & S\end{array}$

46 ccgcgcttggctttcagcaccgcggacagcggcggcggcatgagc $\begin{array}{lllllllllllllll}P & R & L & A & F & S & T & A & D & S & G & G & G & M & S\end{array}$

91 gggctgaacccaggtcccgcggtgcccatgaaggaccacgacgcc $\begin{array}{lllllllllllllll}G & L & N & P & G & P & A & V & P & M & K & D & H & D & A\end{array}$

136 atcaagctcttcgtggggcagatcccgcggggcttggacgagcag $\begin{array}{llllllllllllllll}I & K & L & F & V & G & Q & I & P & R & G & L & D & E & Q\end{array}$

181 gacctcaagccgctgttcgaggagttcggccgcatctacgagctg

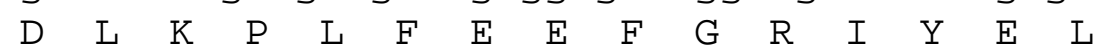

226 acggtgctgaaggaccggctcaccggcctccacaaaggctgtgcc $\begin{array}{lllllllllllllllllllll}T & V & L & K & D & R & L & T & G & L & H & K & G & C & A\end{array}$

271 ttcctcacctactgcgccogggactctgccctcaaggccoagagt

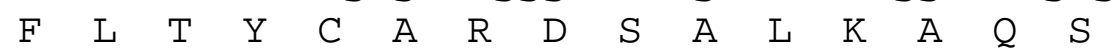

316 gcactgcatgagcagaagaccctgccagggatgaatcgtccgatc $\begin{array}{lllllllllllllll}A & L & H & E & Q & K & T & L & P & G & M & N & R & P & I\end{array}$

361 caagtgaagccggctgccagtgagggccgaggagaggaccggaag $\begin{array}{lllllllllllllll}Q & V & K & P & A & A & S & E & G & R & G & E & D & R & K\end{array}$

406 ctgtttgtggggatgttgggcaagcagcagggtgaggaggatgtc $\begin{array}{llllllllllllllll}L & F & V & G & M & L & G & K & Q & Q & G & E & E & D & V\end{array}$

451 agacgtctgttccagcccttcggccatatcgaggagtgcactgtc $\begin{array}{lllllllllllllllll}R & R & L & F & Q & P & F & G & H & I & E & E & C & T & V\end{array}$

496 ctgcggagtccggacggtaccagtaaaggctgtgcctttgtgaaa

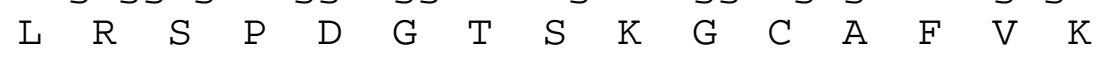

541 ttcggaagtcaaggggaagcccaagctgccatccagggactacac $\begin{array}{llllllllllllllll} & G & G & S & Q & G & E & A & Q & A & A & I & Q & G & L & H\end{array}$

586 ggtagccggacaatgacgggtgcctcctccagcctggtggttaag $\begin{array}{lllllllllllllllllllllll} & G & S & R & T & M & T & G & A & S & S & S & L & V & V & K\end{array}$ 
631 ctggcagacaccgaccgggagcgcgcgctgcgaaggatgcagcaa

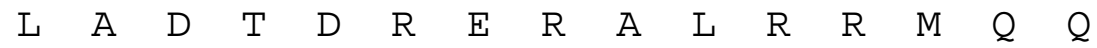

676 atggctggccagctgggtgccttccacccggcaccgctgccctc $\begin{array}{lllllllllllllll}M & A & G & Q & L & G & A & F & H & P & A & P & L & P & L\end{array}$

721 ggggcctgtggcgcctataccactgcgatcctacagcaccaggca $\begin{array}{llllllllllllllll}G & A & C & G & A & Y & T & T & A & I & L & Q & H & Q & A\end{array}$

766 gcgttgctggccgcagcgcagggtccggggttaggccaggtggcc $\begin{array}{llllllllllllllll}A & L & L & A & A & A & Q & G & P & G & L & G & Q & V & A\end{array}$

811 gcggtggccgcccagatgcagcacgtggcggccttcagcttggtg $\begin{array}{lllllllllllllll}A & V & A & A & Q & M & Q & H & V & A & A & F & S & L & V\end{array}$

856 gctgcaccgctgttgcccgcggcagccaatacatcccctggtggc A

901 aatggccctggtgcactccctggccttccagcgcccatgggagtc $\begin{array}{llllllllllllllllll}N & G & P & G & A & L & P & G & L & P & A & P & M & G & V\end{array}$

946 aatggattcggctccttgacccccagagcaacggacagccaggc $\begin{array}{lllllllllllllll}N & G & F & G & S & L & T & P & Q & S & N & G & Q & P & G\end{array}$

991 tccgacacgctctataacaacggggtttccccttacccagcagcc $\begin{array}{lllllllllllllll}S & D & T & L & Y & N & N & G & V & S & P & Y & P & A & A\end{array}$

1036 tatccctcggcctatgccccagcgagcacagctttttcccaacag $\begin{array}{lllllllllllllll}Y & P & S & A & Y & A & P & A & S & T & A & F & S & Q & Q\end{array}$

1081 ccttcagctctgcctcaacaacaaagagaaggccccgaaggctgt $\begin{array}{llllllllllllllll}P & S & A & L & P & Q & Q & Q & R & E & G & P & E & G & C\end{array}$

1126 aacctcttcatctatcacctgcctcaggagtttggggatgcagaa $\begin{array}{lllllllllllllll}N & L & F & I & Y & H & L & P & Q & E & F & G & D & A & E\end{array}$

1171 ctcatacagacattcctgccettcggagctgttgtctctgccaaa $\begin{array}{llllllllllllllll}L & I & Q & T & F & L & P & F & G & A & V & V & S & A & K\end{array}$

1216 gtttttgtggaccgtgccaccaatcagagcaagtgttttgggttt

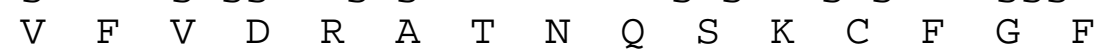

1261 gttagttt tgacaatccaaccagtgcccagaccgccatccaggcc $\begin{array}{lllllllllllllll}V & S & F & D & N & P & T & S & A & Q & T & A & I & Q & A\end{array}$

1306 atgaatggctttcaaatcggcatgaagaggctcaaggtccagcta $\begin{array}{llllllllllllllllllll}M & N & G & F & Q & I & G & M & K & R & L & K & V & Q & L\end{array}$

1351 aagagacctaaggatgccaacaggccttactga 1383

$\begin{array}{llllllllllllll}K & R & P & K & D & A & N & R & P & Y & *\end{array}$

Figure 3.23 (A) Schematic representation of Brunol6 protein domain. (B) Nucleotide sequence (from NCBI) of Brunol6 cDNA. ATG codon, indicating start of translation and TGA terminating codon are bold and coloured in blue.

\subsubsection{Expression analysis of mouse Brunol6 gene}

\subsubsection{Expression analysis of Brunol6 gene during embryonic development}

To examine the expression of Brunol6 gene during embryonic development, RT-PCR analysis was performed on RNA range of embryonic stages. Brunol6 expression was detected as early as 9.5 days post coitum (dpc) stages (Fig. 3.24 B). Interestingly, expression of Brunol6 was detected in ES cells, but not in early preimplantation stages; 2 
cell, 4-cell and 8-cell stages (Fig 3.24 A). Taken together, these data indicate that Brunol6 gene expression starts at $9.5 \mathrm{dpc}$ and is also observed in embryonic stem cells.

\subsubsection{RT- PCR analysis of Brunol6 in adult mouse}

To analyse expression of Brunol6 in adult mouse at the RNA level, total RNA was isolated from multiple adult mouse tissues including brain, heart, liver, lung, testis, ovary, muscle and kidney. By RT-PCR analysis, Brunol6 transcript could be detected from RNA samples of brain and testis. Integrity of the RNA used for RT-PCR was proven by amplification of the Gapdh transcript (Figure 3.24 C). RT-PCR was done also with RNA from testes of different mutants with spermatogenesis defects. Brunol6 transcript was detectable in Leyl-/-, olt/olt and qk/qk mutant but not in $\mathrm{W} / \mathrm{W}^{\mathrm{V}}$, and $\mathrm{Tfm} / \mathrm{y}$ mutants (Figure $3.24 \mathrm{D})$. This indicates that expression starts as early as in spermatocyte stage. Because there is no expression in $\mathrm{W} / \mathrm{W}^{\mathrm{V}}$ and $\mathrm{Tfm} / \mathrm{y}$ mutants, it can be concluded that expression of the gene is restricted to germ cells. Expression studies were also done in postnatal stages. Brunol6 transcript was detectable from day P20 to P40 in all tested postnatal stages (Figure $3.24 \mathrm{E})$.
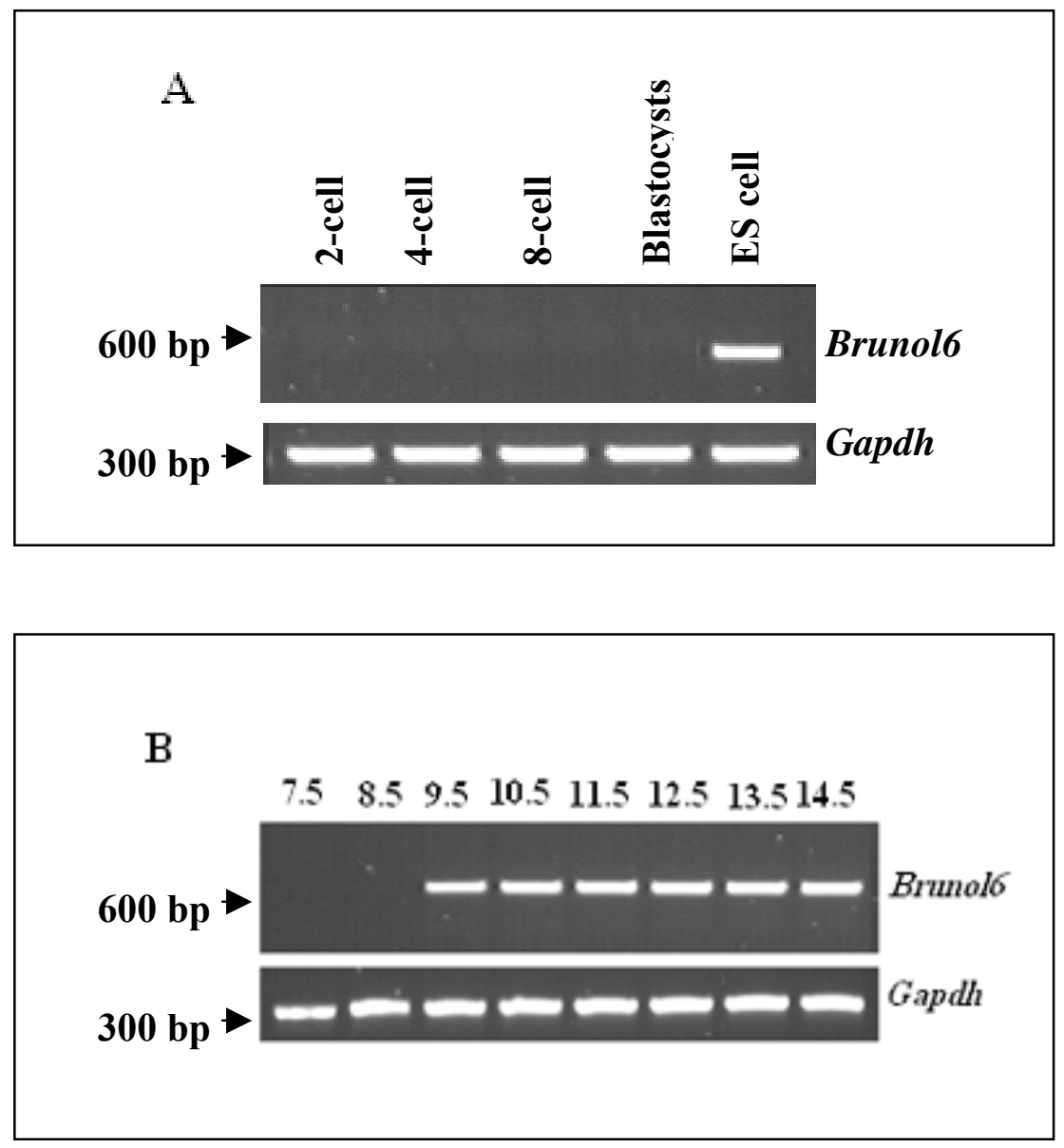
C

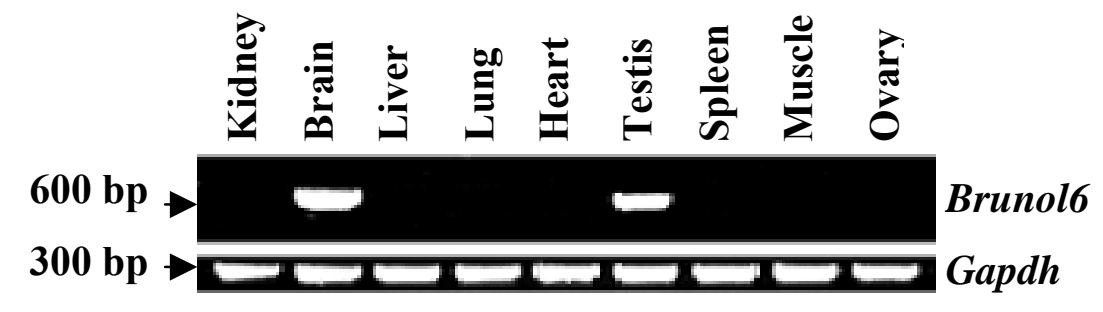

D

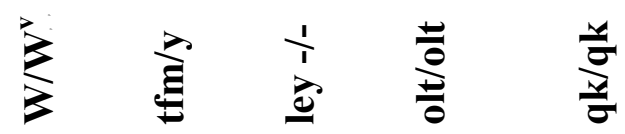

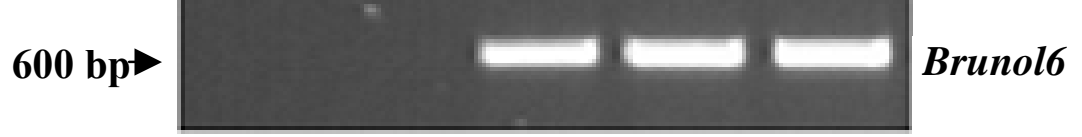

$300 \mathrm{bp} \rightarrow \square \square \square$ Gapdh

$\mathbf{E}$

5D $\quad 10$ D 15 D 20 D 25 D 30 D 60 D

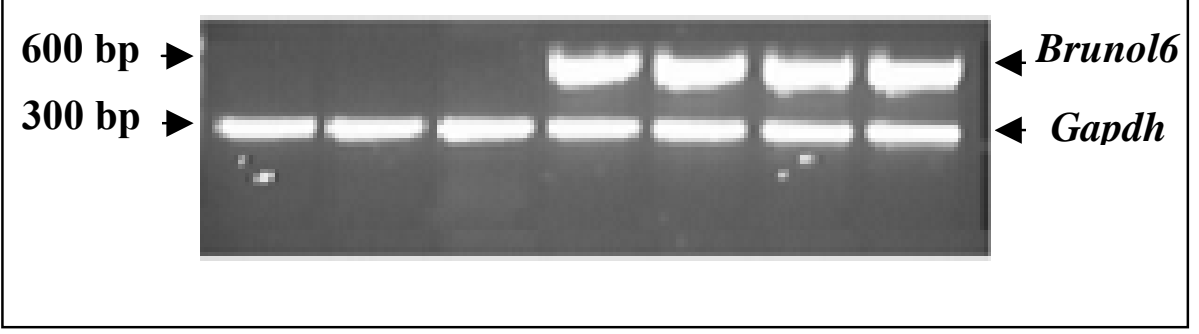


Figure 3.24 RT-PCR expression analysis of Brunol6, (A) In preimplantation stages of development, expression of Brunol6 was detected in ES cells but not in 2, 4 and 8-cell stages. (B) During embryonic development Brunol6 gene expression starts at least at $9.5 \mathrm{dpc}(\mathrm{C})$ In different adult tissues, Brunol6 expression is restricted to the brain and testis, (D) In testes of mutants, expression of Brunol6 is observed in testes of all mutants except $\mathrm{W} / \mathrm{W}^{\mathrm{V}}$ and $\mathrm{Tfm} / \mathrm{y}$ indicating that expression is restricted to germ cells. (E) In postnatal testicular developmental stages, Brunol6 expression is present from P20 onward and was observed in testes of all later stages (P20 to P40).

\subsubsection{Northern Blot analysis of Brunol6 in adult mouse}

To determine the expression of Brunol6 at the Northern blot level, total RNA from brain, liver, lung, muscle, heart, kidney, ovary and testis was size fractionated in an $1 \%$ agarose/MOPS gel containing $5.5 \%$ formaldehyde and blotted onto Hybond-XL membrane. The Northern blot was hybridised with a ${ }^{32} \mathrm{P}$-labelled $500 \mathrm{bp}$ fragment from the 3' UTR of the murine Brunol6 cDNA probe, which detected approximately $3.0 \mathrm{~kb}$ strong hybridisation signal in whole brain sample and testis. No signal was visible in other adult tissues (Fig 3.25).

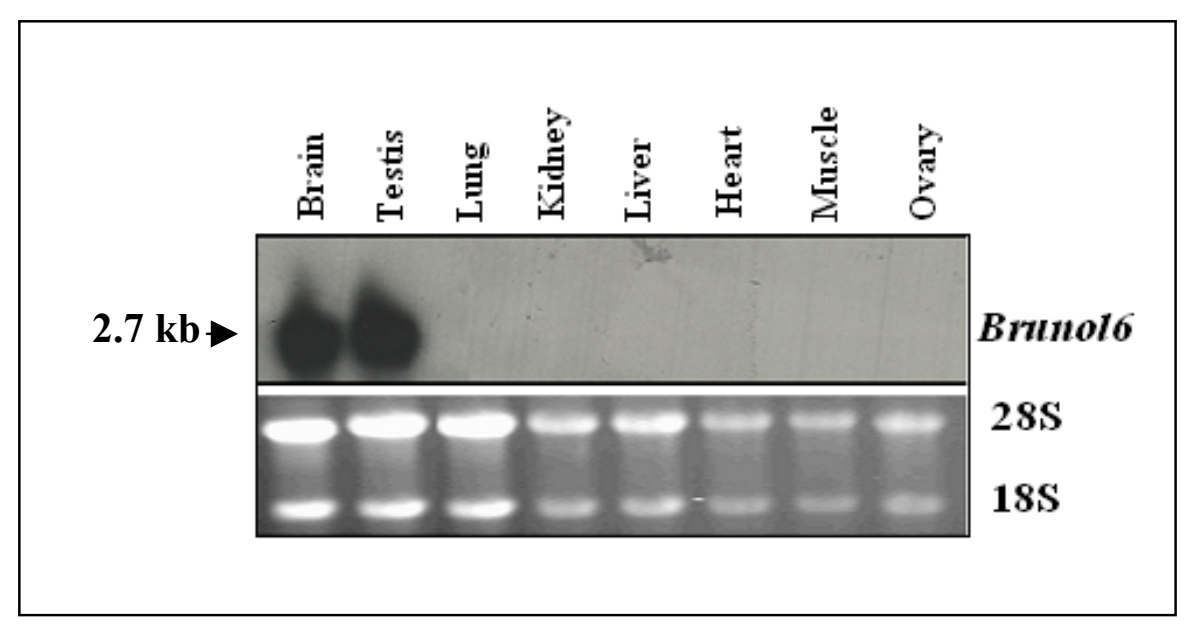

Figure 3.25. Northern Blot analysis of Brunol6 gene in different adult mouse tissues. Total RNA (20 $\mu \mathrm{g})$ was extracted from various tissues including muscle, kidney, ovary, lung, liver, heart, brain and testis of the adult mouse and subjected to Northern Blot hybridization using the 500 bp fragment from the $3^{\prime}$ UTR of Brunol6 as a probe. 


\subsection{Study of the activation of the Brunol4 gene in preimplantation development}

\subsubsection{Expression study of Brunol4 during embryonic development}

Expression analysis of Brunol4 during embryonic development showed that expression of Brunol4 starts at one cell stage and continue to all the stages of embryonic development including 2-, 4-, 8-cell stages and blastocysts (Fig 3.16 A). It is well known that transcripts are synthesised and stored during oogenesis for later use at various stages of oocytes maturation and early embryonic development. To differentiate between maternal transcripts and newly synthesised transcripts of Brunol4 at two-cell stage embryo, complete cDNA of Brunol4 of different mice strains (CD-1, C57 BL, NMRI, 129/Sv and FVB) was sequenced to search for any polymorphism that could differentiate between maternal and paternal transcript. One single nucleotide polymorphism was identified at the 3'UTR of Brunol4 transcript that could differentiate between C57BL and CD-1 mice strains. This polymorphism results in the restriction site for PmI1. By using the PmI1 restriction enzyme it is possible to differentiate between transcript arising from CD-1 or C57 BL mouse strains (Fig 3.26).

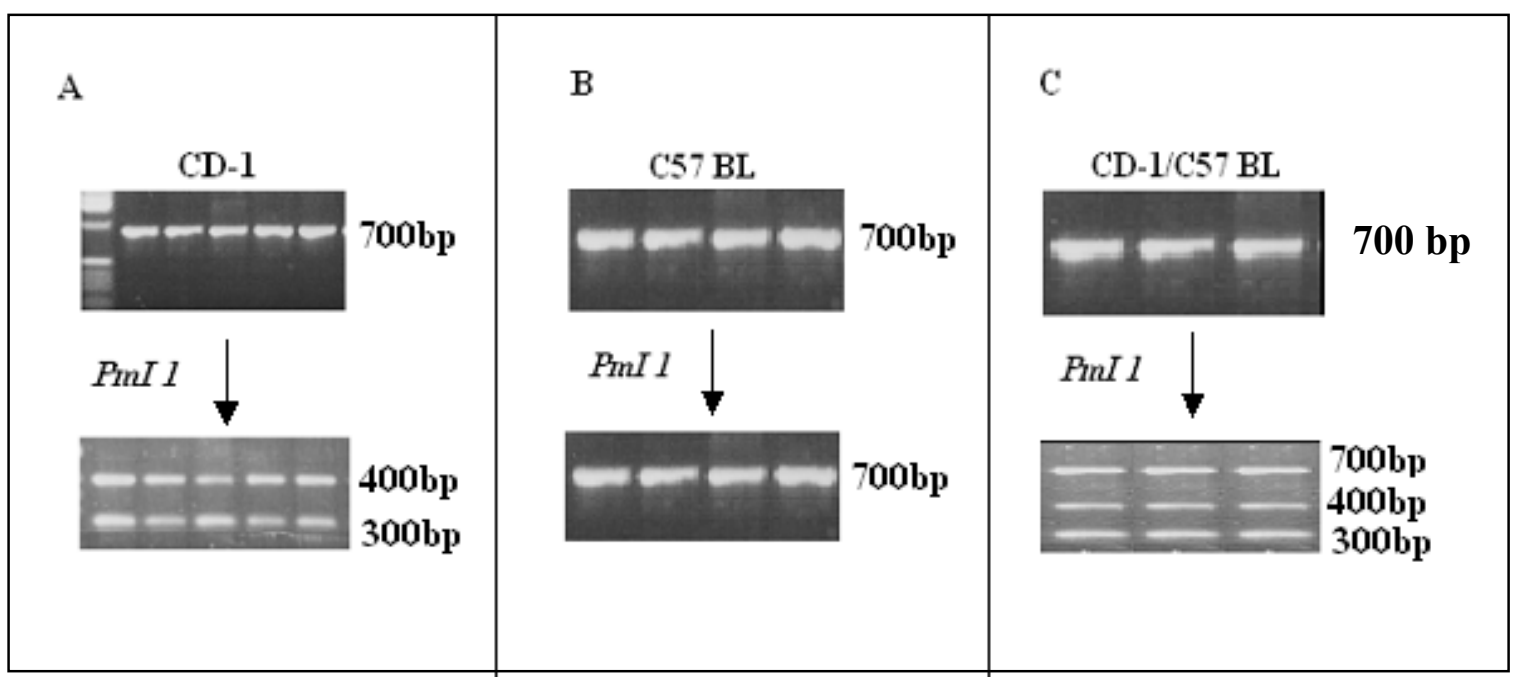

Figure 3.26 Strategy to differentiate between CD-1 and C57BL mouse strains. To differentiate between CD-1 and C57 BL mouse strains, cDNA of CD-1 and C57 BL was subjected to RT- PCR by using Bru4-Exo-13F and Bru4-3'UTR-R primers, which results in a 700 bp long PCR product. (A) When RT-PCR product of CD-1 (700 bp long) was treated with PmI1 restriction enzyme, it was digested and produced two bands (400 bp and 300 bp). (B) When RT-PCR product (700 bp) of C57BL was 
treated with PmI1 restriction enzyme, it was not digested. (C) When RT-PCR product of CD-1/ C57BL was treated with PmI1 restriction enzyme, it was digested and produced three bands $(700$ bp paternal and 400bp + 300bp maternal)

\subsubsection{Expression study of Brunol4 transcript of unfertilised oocytes}

To study the expression of Brunol4 transcript of unfertilised oocytes, we collected 150 unfertilised oocytes from CD-1 female mice. Total RNA was isolated from unfertilised oocytes and directly subjected to RT- PCR by using Bru4-Exo-13F and Bru4-3'UTR-R primers, which resulted in a $700 \mathrm{bp}$ long PCR product (Fig 3.26 A). To further prove our strategy (as described in Fig 3.26) PCR product (700 bp) was digested with PmII restriction enzyme and it resulted in expected $400 \mathrm{bp}$ and $300 \mathrm{bp}$ fragments (Fig 3.27 B).

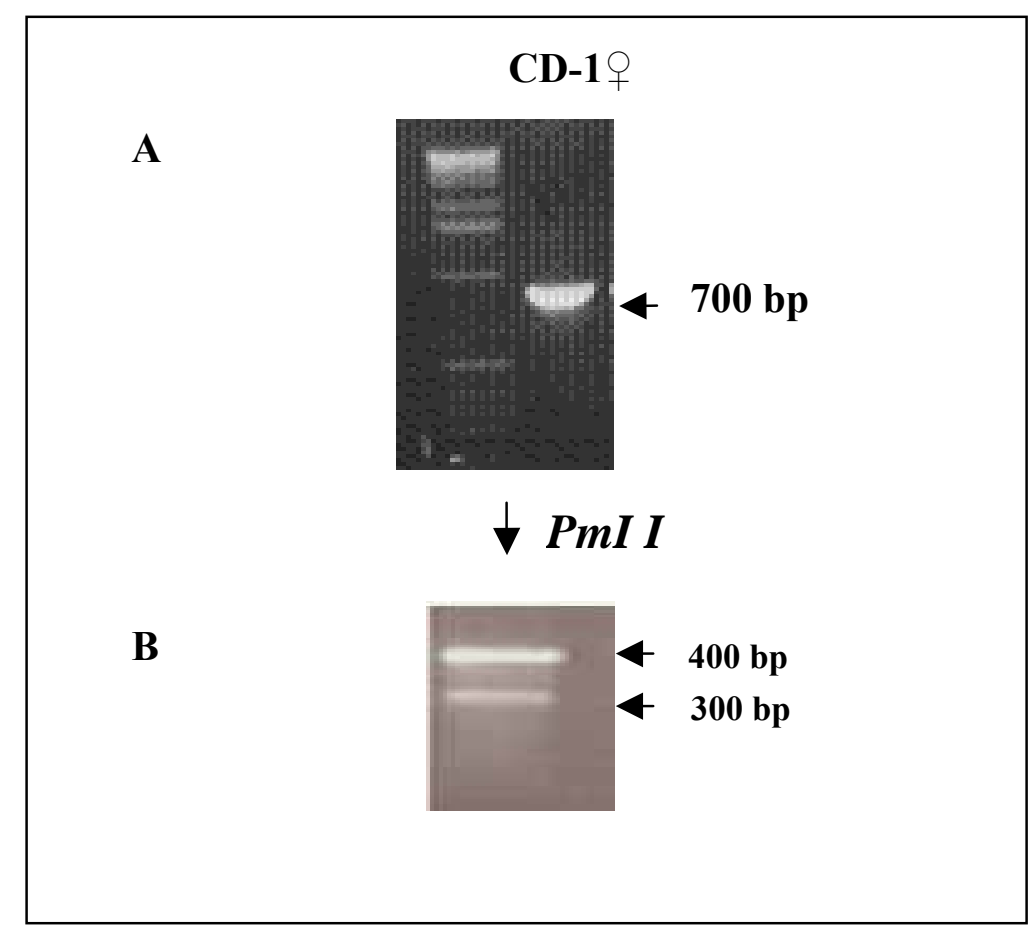

Fig 3.27 Expression study of the Brunol4 transcript of unfertilised oocytes from CD-1 female mice. (A) RT-PCR product (700 bp) was digested with PmI1 restriction enzyme and (B) it resulted in expected $400 \mathrm{bp}$ and $300 \mathrm{bp}$ fragments. 


\subsubsection{Study of the activation of Brunol4 gene at two-cell stage}

To study the activation of Brunol4 gene at two-cell stage, CD-1 male mice were mated with C57BL female and the embryos were collected at two-cell stage (E1.5). Total 220 embryos were collected and RNA was isolated. Isolated RNA was subjected to RT-PCR by using Bru4-Exo-13F and Bru4-3'UTR-R primers. PCR product (700 bp) was digested by PmI1 restriction enzyme to differentiate between maternal and paternal allele. At two-cell stage only maternal allele was found (Fig 3.28). Taken together these observations suggest that at two-cell stage Brunol4 transcript is only maternal

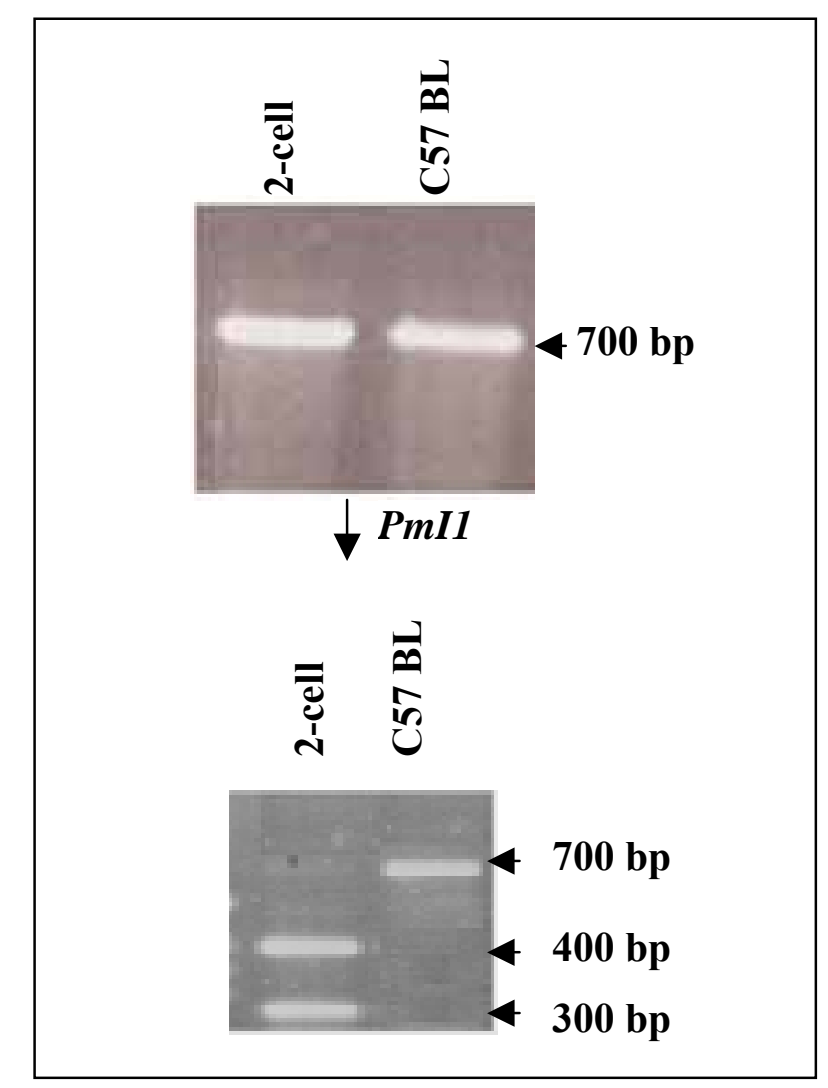

Figure 3.28 Study of the activation of Brunol4 gene at two-cell stage. (A) To differentiate the maternal and paternal allele at two cell stage of embryonic development, RT-PCR product (700bp) of two cell stage and C57BL adult mouse (as a control) was treated with PmI1 restriction enzyme (B) When RT-PCR of two cell stage embryos was treated with PmI1 restriction enzyme it was digested and produced two bands $(400 \mathrm{bp}+300 \mathrm{bp})$ while the RT-PCR product of C57BL adult mouse (as a control) treated with PmI1 restriction enzyme was not digested. 


\subsubsection{Study of the activation of Brunol4 gene at four- and eight-cell stage}

Activation study at two-cell stage showed only the maternally stored transcript of Brunol4. To study the activation of Brunol4 gene at four-cell stage, CD-1 male mice were mated with C57BL female and the embryos were collected at two-cell stage (E1.5). To avoid any maternal contamination, embryos were cultured with the M16 medium (Sigma) to 4 cell (E2.5) and 8-cell (E3.0) stages. Total 190 embryos were collected at 4-cell stage and 140 at 8-cell stage. Total RNA was isolated from 4-cell and 8-cell stages embryos. Isolated RNA was subjected to RT-PCR by using Bru4-Exo-13F and Bru4-3'UTR-R primers. PCR product was digested by PmI1 restriction enzyme to differentiate between maternal and paternal allele. At four-cell stage only paternal allele was observed and at 8-cell stage both maternal and paternal alleles were observed (Fig 3.29 A). Taken together these observations suggest that at four-cell stage of embryonic development only paternal allele of Brunol4 is transcribed while at 8-cell stage of embryonic development both maternal and paternal alleles are active.

To further prove this result of Brunol4 gene activation the breeding strategy was changed

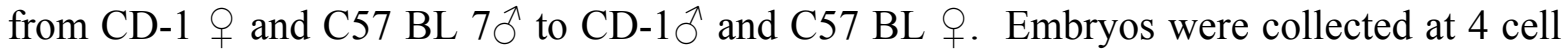
and 8 cell stages. Total RNA was isolated from 4-cell (180) and 8-cell (158) stage embryos. Isolated RNA was subjected to RT-PCR by using Bru4-Exo-13F and Bru4-3'UTR-R primers. PCR products were digested with PmI1 restriction enzyme to differentiate between maternal and paternal allele. At four-cell and 8-cell stage, both maternal and paternal alleles were observed. Interestingly at 4-cell stage of embryonic development, the intensity of paternal allele was very strong while the maternal allele was very weak (Fig 3.29 B). Result of activation of Brunol4 gene during early embryonic development is summarized in (Table 3.9). Taken together these observations suggest that the activation of Brunol4 gene starts at 4-cell stage but at this stage paternal allele is expressed preferentially (Fig 3.29B).

\begin{tabular}{|l|c|}
\hline $\begin{array}{c}\text { Stages of embryonic } \\
\text { development }\end{array}$ & $\begin{array}{c}\text { Activation of Brunol4 transcript } \\
\text { (maternal or paternal) }\end{array}$ \\
\hline Unfertilized oocytes & Maternal transcript \\
\hline 2-cell stage & Maternal transcript \\
\hline 4-cell stage & $\begin{array}{l}\text { Both maternal and paternal transcripts but } \\
\text { paternal allele is expressed preferentially }\end{array}$ \\
\hline 8-cell stage & Both maternal and paternal \\
\hline
\end{tabular}


Table 3.9 Result of activation of Brunol4 gene during early embryonic development. At unfertilized oocytes and 2-cell stages only maternal allele is transcribed. At 4-cell stage both maternal and paternal alleles are transcribed but paternal allele is expressed preferentially. At 8-cell stage both maternal and paternal alleles are expressed equally.
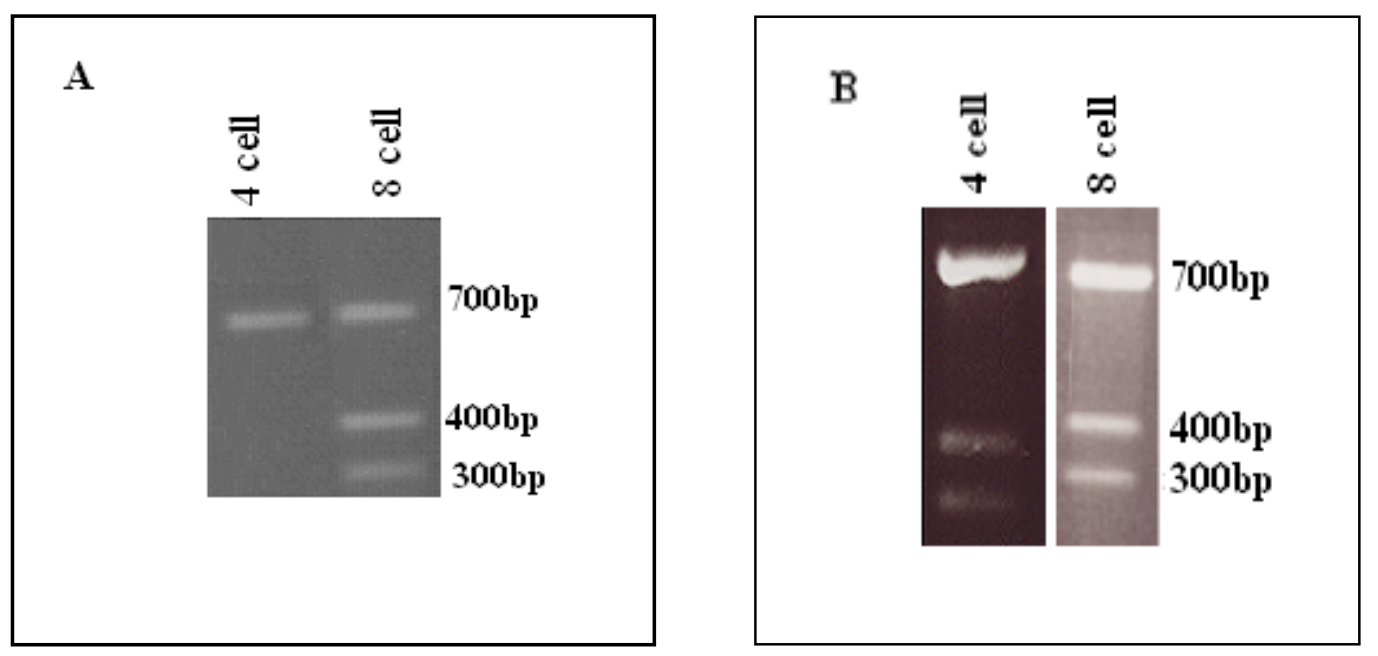

Figure 3.29 Strategy to differentiate between expression of maternal and paternal allele at four-cell and eight-cell stages of embryonic development. (A) RT-PCR product of 4- and 8- cell stages, (CD-1 $\bigcirc$ X C57BL $\odot$ ) was treated with PmI1 restriction enzyme; at 4-cell stage only a single band (700bp) represents the paternal allele and at 8-cell stage three bands represents both maternal $(400 \mathrm{bp}+300 \mathrm{bp})$ and paternal allele (700bp). (B) RT-PCR product of 4 and 8-cell stages (CD-1 $q$ X C57BL $\overbrace{}^{\Uparrow})$ was treated with PmI1 restriction enzyme. At 4-cell stage three bands could be observed, one strong band $(700 \mathrm{bp})$ represent the paternal allele, two-week bands $(400 \mathrm{bp}+300 \mathrm{bp})$ represents the maternal allele and at 8 -cell stage three bands represent both maternal and paternal allele. 


\section{Discussion}

RNA-binding proteins are the cog-wheels of molecular machines that regulate gene expression at the post-transcriptional level. As cog-wheels they interact also with other proteins and transmit specific packets of information. However, they do not always fulfil exclusive functions and according to their localization certain can enter into different molecular machineries that ensure different functions. The Elav/Bruno RBPs represent a superfamily of RNA binding proteins. The members of the elav gene family encode RNA binding proteins (RBPs) that contain a highly conserved structure of three RNA recognition motifs (RRMs). The prototype of this gene family, the elav gene, was identified in Drosophila as a neural specific gene (Yao et al.,1993). In human and mouse, six Bruno-like genes have been identified, whereas other species such as Drosophila, Xenopus laevis, and Caenorhabditis elegans have at least two members of this family, and related genes have also been detected in plants and ascidians. The importance of RBPs in development is underscored by the isolation of mutants with interesting developmental phenotypes where the defective gene encodes an RBP (Yao et al., 1993).

The initial aim of the present study was the elucidation of the mechanistic role of Brunol1 and Brunol4 (members of Elav/Bruno family) in cerebral development and spermatogenesis. For this purpose, knockout alleles of Brunol1 and Brunol4 were isolated to determine, whether these genes have unique or redundant function.

In the first part of this thesis, Elav/Bruno RBPs family and its evolutionary conservation is discussed. Results concerning about expression analysis of Brunol1, its subcellular localisation as well as functional analysis of Brunol1 by generating knockout mice are discussed. In the second part, expression analysis of Brunol4 gene, generation of the Brunol4 knockout mice and its possible duplication are discussed. Finally we discuss the results of expression analysis of Brunol6 and genome activation strategy of Brunol4.

\subsection{Evolutionary conservation of Elav/ Bruno family}

Elav is the superfamily of RBPs that contains a conserved domain, called the RNA recognition motif (RRM). The genes of Elav/Bruno family are conserved through evolution with members present in plants, worms, fruit flies, and vertebrates (Good et al., 2002). The RNA recognition motif (RRM) is highly conserved domain and contain a 80-90 amino acid domain (Siomi and Dreyfuss, 1997) The most highly conserved sequences within the RRM are the ribonucleoprotein motifs (RNP1 and RNP2) that are signature sequences for the 
RRM and have been shown to specifically interact with RNA (Nagai et al., 1994). A multiple sequence alignment of the putative mouse, human, and C. elegans of full-length Bruno family of proteins to the Drosophila Bruno and Xenopus BrunoL-1 is presented in figure 4.1. Most of the sequence conservation is within RNP of the RRMs. The aminoterminal and linker regions of the three RRMs are highly variable in different proteins. The third RRM has the most sequence conservation in the different proteins. The sequence of the linker region contains no identifiable motifs. However, several of the Bruno proteins have homopolymeric amino acid tracts such as the stretches of glutamine in mouse Brunol1, C. elegans Etr-1 and Xenopus BrunoL-1. The possible function of this domain is not known.

All members of the Bruno family share a common domain structure with the Elav family of proteins. A dendrogram based on a pair wise comparison of all members of the Bruno and vertebrate Elav family is presented in figure 4.2. The Elav proteins form a distinct group of proteins. A yeast protein, PUB1, has a domain structure similar to Bruno but is most similar to the Elav family of proteins. The vertebrate Bruno proteins fall into two subfamilies, one containing Brunol2 and Bruno3 and the other containing Brunol1, Brunol4, Brunol5, and Brunol6.

Comparison of the amino-terminal and linker regions of proteins within subfamilies reveals some sequence similarity in these regions. Orthologous proteins in Xenopus have been identified for BRUNOL1, BRUNOL2 and BRUNOL3; presumably the frog Brunol-4, Brunol-5, and Brunol-6 have not yet been identified. The similarity of the domain structure but divergence of the primary sequence from the Elav proteins that are involved in many different RNA processing events both during development and in normal cell function (Good, 1997; Antic and Keene, 1997) suggests that the Bruno proteins may have related roles in regulating target RNAs but bind to different subsets of mRNAs than the Elav-like proteins.

A

\begin{tabular}{|c||c|c|c|}
\hline RRM1 & RRM2 & Divergent Domain & RRM3 \\
\hline
\end{tabular}


B

Xenopusl.ETR-3 - - - - - - IKMFVGQIPRSWEKELKDLFEPYGAVYQINVLRDRSQNPPQSKGCCFVTFYTRKAALE Similar to ETR-1----AIKLFIGQIPRNLEKDLKPLFEEFGKIYELTVLKDRFT - MHKGCAFLTYCERESALK Human BRUNOL4 -- - - - AIKLFIGQIPRNLEKDLKPLFEEFGKIYELTVLKDRFT - MHKGCAFLTYCERESALK Mouse Brunol4--..-- AIKLFIGQIPRNLEKDLKPLFEEFGKIYELTVLKDRFT - MHKGCAFLTYCERESALK Mouse Brunol1--.---AIKLFVGQIPRHLEKDLKPIFEQFGRIFELTVIKDKYT--LHKGCAFLTYCARDSALK Mouse Brunol6--.- - - AIKLFVGQIPRGLDEQDLKPLFEEFGRIYELTVLKDRLT - LHKGCAFLTYCARDSALK Xenopusl.ETR-1 - - - - - AIKLFIGQIPRNLEKDLKPIFEQFGKIYELTVIKDKFT - MHKGCAFLTYCARESALK Danio rerio ETR-1--- -AIKLFIGQIPRNLEKDLKPIFEQFGKIYELTVIKDKYT - MHKGCAFLTYCARESALK Human BRUNOL5---.-- - AIKLFVGQIPRHLEKDLKPLFEQFGRIYELTVLKDPYT - MHKGCAFLTYCARDSAIK C.elegans ETR-1---- -AIKMFVGQIPRQWETDCRRLFEKYGSVFSCNILRDKS - - ASKGCCFVTFYHRKDAIE Consensus sequence

LFVGN

$\begin{array}{llcccc}\text { E } & \text { L } & \text { F } & \text { FG } & \text { I } & \text { I } \\ \text { D } & & & \text { V } & \text { V }\end{array}$

KGFGFVXF

A V

Xenopus1. ETR - 3 - - - - AQNALHNIKTLPGMHHPIQMKPADSEKSNAVE - - - - - - - - RKLFIGMVSKKCNENDIRV Similar to ETR-1--AQSALHEQKTLPGMNRPIQVKPADSESRGGSSCLRQPPS--HRKLFVGMLNKQQSEDDVRR Human BRUNOL4 - - - -AQSALHEQKTLPGMNRPIQVKPADSESRGGSSCLRQPPS - - DRKLFVGMLNKQQSEDDVRR Mouse Brunol4----AQSALHEQKTLPGMNRPIQVKPADSESRGGSSCLRQPPSH RKLFVGMLNKQQSEDDVRR Mouse Brunol1--.--AQSALHEQKTLPGMNRPIQVKPADSESRGD- - - - - - - - - KLFVGMLGKQQTDEDVRK Mouse Brunol6-- - - AQSALHEEQKTLPGMNRPIQVKPAASEGRGED - - - - - - - RKLFVGMLGKQQGEEDVR Xenopus 1. ETR-1--AQSALHEQKTLPGMNRPIQVKPADSESRGED-- - - - - - - LFVGMLGKQQTDEDVRR Danio rerio ETR-1-AQNALHEQKTLPGMNRPIQVKPADSEGRGD- - - - - - - - RKLFVGMLGKQLSDADVRK Human BRUNOL5 - - - - AQTALHEQKTLPGMARPIQVKPADSESRGGR - - - - - - - DRKLFVGMLNKQQSEEDVLR C. elegans ETR-1---AQGALHNIKVIEGMHHPVQMKPADTENRNE - - - - - - - KLFIGQLSKKHNEENLRE Consensus sequence

L G

LFVGNL E

I D

\section{RRM2}

Xenopus 1.ETR-3- - - - - FSPFGQIEECRILRGPDGLSRGCAFVTFSTRAMAQNAIKAMHQSQTMEGCSSPIVVKFA Similar to ETR-1---LFEAFGNIEECTILRGPDGNSKGCAFVKYSSHAEAQAAINALHGSQTMPGASSSLVVKFA Human BRUNOL4-- - - - LFEAFGNIEECTILRGPDGNSKGCAFVKYSSHAEAQAAINALHGSQTMPGASSSLVVKFA Mouse Brunol4--.-- LFEAFGNIEECTILRGPDGNSKGCAFVKYSSHAEAQAAINALHGSQTM GASSSLVVKFA Mouse Brunol1--.-- MFEPFGTIDECTVLRGPDGTSKGCAFVKFQTHAEAQAAINTLHSSRTLPGASSSLVVKFA Mouse Brunol6--..--MFQPFGHIEECTVLRSPDGTSKGCAFVKFGSGAEAQAAIQGLHGSRTMTGASSSLVVKFA Xenopusl.ETR-1 - - - - - FEPFGNIDECTVLRGPDGTSKGCAFVKFQTHTEAQAAINALHGSRTLPGASSSLVVKFA Danio rerio ETR-1--MFEPFGSIEECTVLRGPDGASKGCAFVKYQSNAEAQAAISALHGSRTLPGASSSLVVKFA Human BRUNOL5---.--LFQPFGVIDECTVLRGPDGSSKGCAFVKFSSHTEAQAAIHALHGSQTMPGASSSLVVKFA C.elegans ETR-1----IFAKFGHIEDCSVLRDQDGKSRGCAFVTFTNRSCAVAATKEMHHSQTMEGCSAPLVVKFA $\begin{array}{lllllr}\text { Consensus sequence } & \text { FG I } & \text { V } & \text { KGFGFVXF } & \text { A } & \text { L G } \\ & \text { I } & & \text { I }\end{array}$

Xenopusl.ETR-3-- - - - DTQKDKEQRRLQQQLAQ - - - - - - - QMQQLN-ATWGNLTGLGGLTPQYLALLQQ

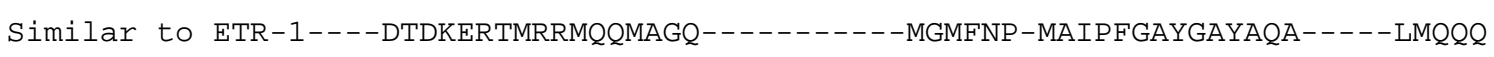




\section{DISCUSSION}

Human BRUNOL4 - - - - DTDKERTMRRMQQMAGQ - - - - - - MGMFNP - MAIPFGAYGAYAQA - - - LMQQQ

Mouse Brunol4- - - DTDKERTMRRMQQMAG - - - - - - - MGMFNPMAIPFGAYGAYAQA - - - - - LMQQQ

Mouse Brunol1 - - - - DTEKERGLRRMQQVATQ - - - - - - - - LGMFSP - - - - IALQFGAYSAYTQLMQQQ

Mouse Brunol6-..-- DTDRERALRRMQQMAGQ - - - - - - - LGAFHPAPLPLGACGAYTT - - - - LMQQQ

Xenopusl.ETR-1 - - - - DTEKERGLRRMQQVANQ - - - - - - - - LGMFSP - IALQFGAYSAYTQAVSDQLMQQQ

Danio rerio ETR-1--DTEKERGIRRMQQVASQ- - - - - - - - LGVISP-MNLHLGAYNAYTQA - - - LVQQQ

Human BRUNOL5 - - - - DTDKERTLRRMQQMVGQ- - - - - - - LGILTPSLTLPFSPYSAYAQA - - - LMQQQ

Xenopusl. ETR-3---ATTPSNLGAFSGIQQMAGMNALQLQNLATLA A A A AAAQTSATT-TNVNPLSTTA Similar to ETR-1---AALMASVAQGGYLNPMAAFAAAQMQQMAALNMNGLAAAPMTPT - - - - - SGGSTPPGITA Human BRUNOL4--.-- - AALMASVAQGGYLNPMAAF AAAQMQQMAALNMNGLAAAPMTPT - - - - SGGSTPPGITA Mouse Brunol4- - - - AALMASVAQGGYLNPMAAFAAAQMQQMAALNMNGLAAAPMTPT - - - - - SGGSTPPGITA Mouse Brunol1-..-.-AALVAAHSAYLSPMATM AA VHDAAHGCHQ C Q W PHRHPHHSI-LRNQHPSCHCC Murine Brunol6-..- - AALLAAAQGPGLGQVAAVAAQMQHVAAFSLVAA - - - - - PLLPAAANTSPGGNGPGAL Xenopus1. ETR-1----AALVAAHSAYLNPMATMAAVQMQQMATINPNGIIATPITQINPITSS--SGTSTPPTLTA Danio rerio ETR-1--AALV-----AQSAYLSPVATVAAVQMQQLAALNPSSIIATPIASIT SSGTSTPPTIAA Human BRUNOL5 - - - - - TTVLS - - - - - TSGSYLSPGVAFSPCHIQQIGAVSLNGLPATPVAPA-SGLHSPPLLGT C.elegans ETR-1----QGQQQ---QHQQQQNVLGILGTVLSALGKLTEGGDDASAKSSSEKPRHQALMTSPAPTAT

Xenopusl. ETR-3----SALGALTSPVAASTANS--SAGAAMNSLTSLGTLQGLAGATVGLNNINALAGTVNSMAAL

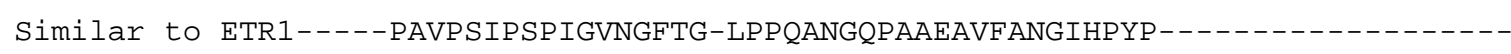

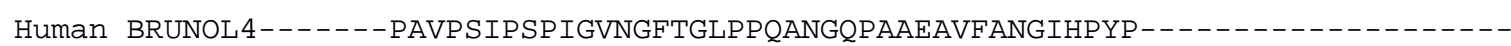

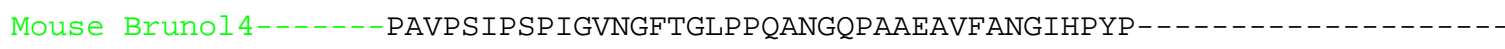
Mouse Brunol1 -----HARLCHPCCLGRQRLQPGAHPAYTGQPAPDALYPNGVHPYPDEALSAERSAGGVPIMSQA

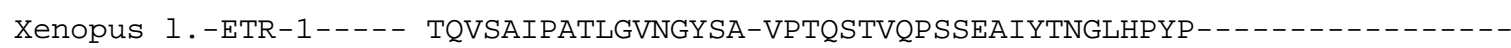
Danio rerio ETR-1 - - TPVPALPPPIAVNSYPP-VPAAPNGQSASEALYTNGVHPYQ - . - . - . - .

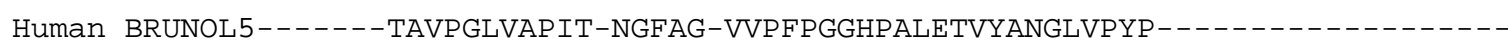
C.elegans ETR-1----SSTSSSASHHHQQHQQQLSQQQQQQQHPQQQGLGNPLLGNPAMAAQNQFDAITMAQIAHQ

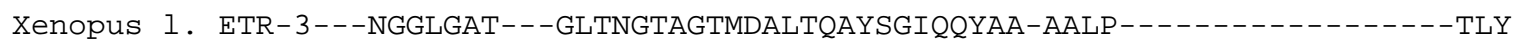

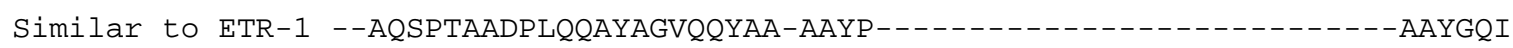
Human BRUNOL4 - . - AQSPTAADPLQQAYAGVQQYAGPAAYP $\ldots$ Mouse Brunol4.....AQSPTAADPLQQAYAGVQQYAGPAYP $\ldots \ldots$

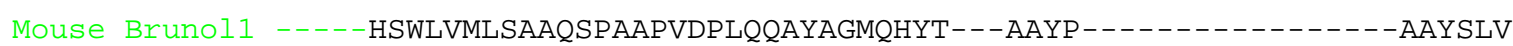
Mouse Brunol6 _..-GQLGAFHPAPLPLGACGAYTT - . Xenopus 1. ETR-1 --AQSPVAQLDPLQQAYAGMQHYT-AAYP

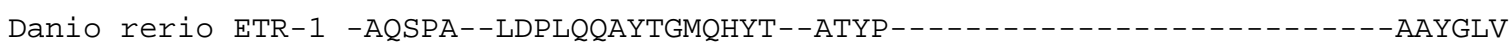

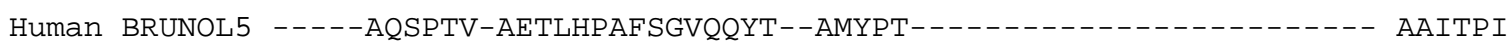
C.elegans ETR-1---QQMLALQGFAVQQGAPSQQQQGLAGGMAGAKTTSPVAASLANHQQIALTPFAGGAAAALDH

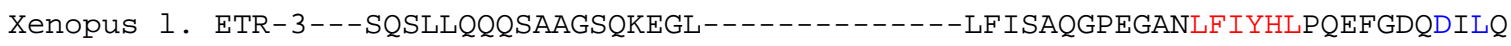
Similar to ETR-1 - SQAFPQPPPMIPQQ - - - - - - - - - Human BRUNOL4 - - - SQAFPQPPPMIPQQ - - - - - - - -

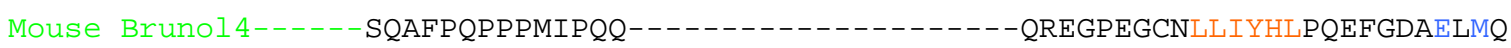
Mouse Brunol1-...- APAFPQPPALVAQQPPPPPQQQQQQQQQQQQQ-QREGPDGCNIFIYHLPQEFTDSEILQ 
Xenopus 1. ETR-1--SPAFTQPPAIIQQQPP-- - - - - - Q - - - Danio rerio ETR-1--GQPFPHQPTLVAQQPQQP-.-.-.-.-.QQLQQ-REGPEGCNIFIYHLPQEFTDSEMLQ

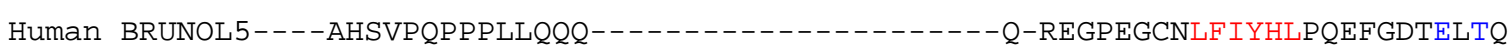
C.elegans ETR-1----FQAMQQYALLANLQATGGVGVQATTSAAQMVGNGDVKGPDGANLFIYHLPQDFGDSDLIN Consensus sequence IYIKGM

\section{RRM3}

Xenopus 1. ETR-3--- MFMPFGNVISAKVFIDKQTNLSKCFGFVSYDNPVSAQAAIQAMNGFQIGMKRLKVQLKRS

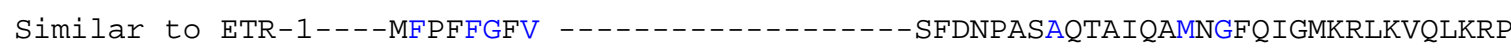

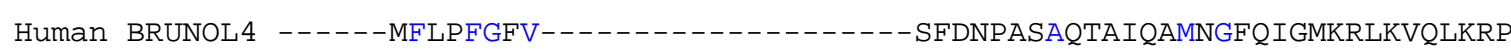

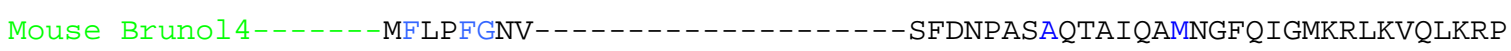
Murine Brunol1-..-- MFVPFGHVISAKVFVDRATNQSKCFGFVSFDNPASAQAAIQAMNGFQIGMKRLKVQLKRP Murine Brunol6--..--TFLPFGAVVSAKVFVDRATNQSKCFGFVSFDNPTSAQTAIQAMNGFQIGMKRLKVQLKRP Xenopus 1. ETR-1----MFLPFGNVISAKVFVDRATNQSKCFGFVSFDNPGSAQAAIQAMNGFQIGMKRLKVQLKRP Danio rerio ETR-1---MFLPFGNVISAKVFVDRATNQSKCFGFVSFDNPASAQAAIQAMNGFQIGMKRLKVQLKRP Human BRUNOL5--.- - MFLPFGNIISSKVFMDRATNQSKCFGFVSFDNPASAQAAIQAMNGFQIGMKRLKVQLKRP C.elegans ETR-1-- - -TFAPFGGILSAKVFIDKVTNLSKCFGFVSYENAQSATNAISAMNGFQIGSKRLKVQLKVD $\begin{array}{llllllll}\text { Consensus sequence } & F & F G V & R & Y & Y & A & M\end{array}$

Fig. 4.1 The Brunol family members are closely related. (A) All of the Brunol proteins possess the same domain structure: three RRMs and a divergent domain of unknown function between RRM2 and RRM3 (B) Evolutionary relationship of mouse Brunol1, Brunol4 and Brunol6 proteins, sequence alignment of Elav/Brunol family with other species are shown. The sequences of the RNP of motifs are coloured red, the consensus sequence of the motifs are coloured blue (Birney et al., 1993; Burd and Dreyfuss, 1994) 


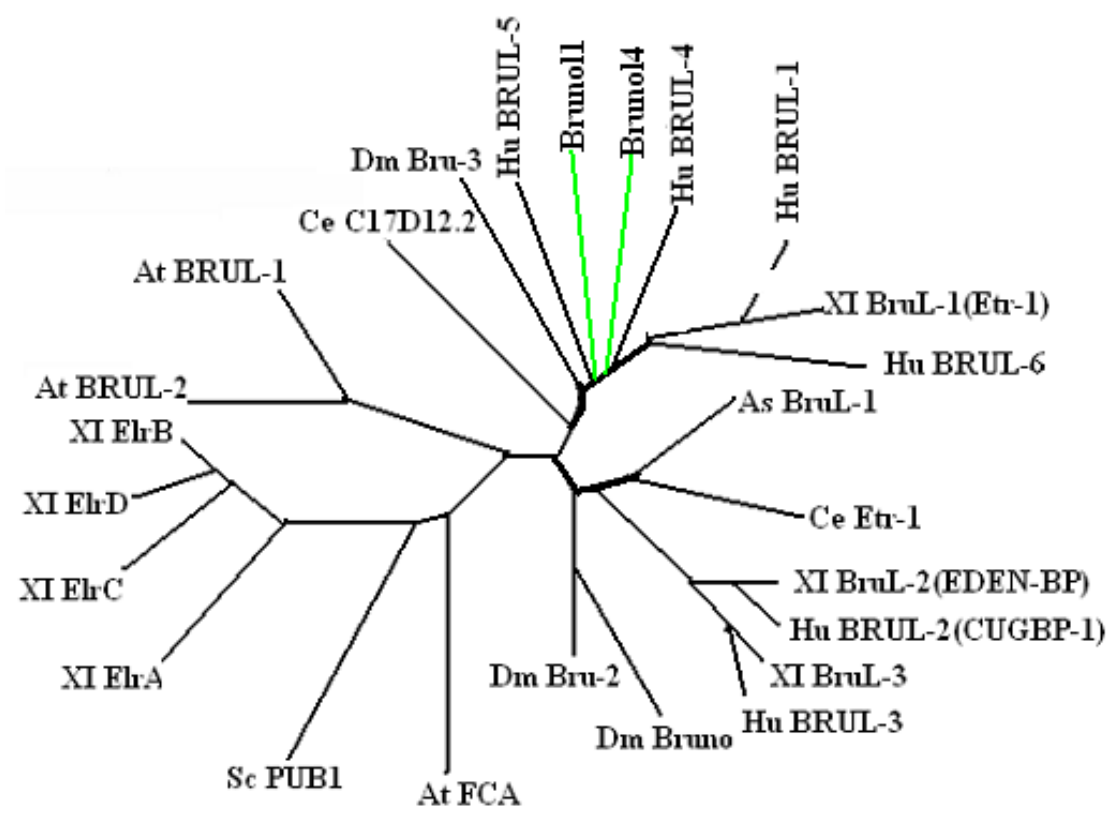

FIG. 4.2 Dendrogram of Bruno family multiple sequence alignments according to Good et al. (2002) extended by mouse protein Brunol1, Brunol4 and Brunol6. The well-known and predicted Bruno proteins (derived from the well-known EST clones) were compared with the program ClustalW and a radial tree displayed using Tree View. The proteins aligned are as follows: XI EDEN-BP/XI BruL-2 (AF003923), At (Arabidopsis) FCA (Z82989), At BruL-1, encoded by gene F21B7.26 (AC002560), At BruL-2, encoded by gene T4I9.1 (AF069442). Members of the Xenopus Elav family: EIrA, ElrB, EIrC, and EIrD and the yeast PUB1 (L20767) are included for comparison to the Bruno proteins. As, ascidian sequences from $H$. roretzi.

\subsection{Expression analysis of Brunol1 gene}

\subsubsection{RT-PCR analysis of Brunol1 during embryonic development}

RT-PCR analysis of Brunol1 during development shows that, its expression starts at 9.5 dpc. Although we also analysed the expression of Brunol1 during preimplantation stages of embryos, we could not detect the Brunol1 expression in preimplantation stages. 
Interestingly, Brunol1 RT-PCR signal was also observed in embryonic stem cells (ES cells). ES cells are derived from inner cell mass (ICM), a cluster of pluripotent stem cells, which exist only temporarily in blastocysts and have the capacity to differentiate into all types of embryonic tissues (Temple, 2003). Because ES cells are obtained from blastocysts, it suggests that Brunol1 could be expressed at such an early stage of mouse development. Similar situation is, for example, in the case of transcription factor Oct4, which is initially expressed in ICM (Schoeler et al., 1990). However, expression of Oct4 was observed also in preimplantation stages, which was not the case for Brunol1 (Fig.3.2). This early expression suggests, that Brunol1 might have a function during very early stages of embryonic development (blastocyst stage).

\subsubsection{RT-PCR analysis of Brunol1 in adult mouse}

In RT PCR analysis of Brunol1 in adult mouse tissues (brain, heart, liver, lung, testis, ovary, muscle and kidney) we have found that Brunol1 transcript is restricted to brain and testis. Additionally, RT-PCR was performed on RNA isolated from testes of different developmental mutants. Because the RT-PCR product was observed in all of the mutants except $\mathrm{W} / \mathrm{W}^{\mathrm{V}}$. mice and $\mathrm{Tfm} / \mathrm{y}$, it proves that expression of Brunol1 is restricted to germ cells and it is not expressed in Sertoli or Leydig cells of testis (Fig. 3.32B). We also performed RT-PCR on RNA isolated from the testes of males of different postnatal stages. Brunol1 signal was detected in testes of 20, 25, 30 and 40 days old males (Fig 3.3 C). Appearance of Brunol1 transcript in day 20 correlates with the appearance of secondary spermatocytes. It is known that post-transcriptional control is a major form of gene regulation during mammalian gametogenesis. In haploid spermatids, proteins required for sperm morphogenesis are synthesized from stores of polyadenylated mRNAs packaged as cytoplasmic ribonucleoprotein particles (RNPs). Unknown signaling events promote unmasking, translational activation, deadenylation and the eventual degradation of translationally repressed mRNAs. Several proteins have been proposed to function as translational regulators in spermatids.

Chromosome condensation in mammalian spermatids involves an initial displacement of the somatic histones with the testis-specific transition proteins TP1 and TP2, and their subsequent replacement by the protamines (Bellve, 1979). The protamine genes Prm1 and Prm2 encode small basic proteins first transcribed in haploid round spermatids (Mali et al., 1989). The protamine mRNAs are stored in translationally inert mRNP particles for up to 
10 days, until translational activation in elongated spermatids (Balhorn et al., 1984; Kleene et al., 1984; Kleene and Flynn, 1987). Translational regulation of the protamine mRNAs is mediated by sequences in their 3' untranslated region (3' UTR) (Braun et al., 1989; Fajardo et al., 1997; Zhong et al., 2001). Translation of the transition protein mRNAs, as well as that of other mRNAs required for spermatid differentiation, is also repressed during spermiogenesis (Balhorn et al., 1984; Mali et al., 1989). Translational repression occurs at a time when other mRNAs are actively being translated, indicating that repression is message specific (Braun, 1998). Several RNA binding proteins have been identified which are expressed in meiotic spermatocytes and postmeiotic spermatids for example like Msy1, Msy2 and Msy4 (Oko et al., 2001). It has been known that Msy2 interacts with Msy4 and binds to the 3'UTR of Prm1 mRNA and controls its regulation (Giorgini et al., 2001) Another RNA binding protein, Tarbp2, functions as a translational regulator during mouse spermatogenesis by binding to the Prm1 mRNA (Lee et al., 1996). The meiotic spermatocytes and postmeiotic spermatids specific expression of Brunol1 shows that it might also control the regulation of Prm1 or promote unmasking, translational activation, deadenylation and the eventual degradation of translationally repressed mRNAs. In order to know the exact role of Brunoll protein during spermatogenesis, the target mRNA is yet to be identified.

\subsubsection{Expression analysis of Brunol1 in adult mouse by Northern blot}

Expression analysis of Brunol1 in adult mouse tissues shows that a large transcript of approximately $4.0 \mathrm{~kb}$ and a smaller transcript of approximately $2.7 \mathrm{~kb}$ are exclusively restricted to brain and testis (Fig 3.4). The differentially spliced region of exon 10 is not enough to explain the difference in size between the two Brunol1 mRNA isoforms seen by Northern blotting. Size differences are usually attributable to differences in polyadenylation. Indeed, there are numerous mouse Brunol1 ESTs that extend beyond the polyadenylated end of 3'UTR of Brunol1 sequence in database suggesting that a down stream polyadenylation site is some time used. Brain and testis specific expression of Brunol1 is making it a new member of an expanding family of brain/testis protein. Other proteins with expressions restricted to the brain and testis have been shown to have a variety of functions including important role in neurogenesis and spermatogenesis (Noce et al., 1993; Connor et al., 1995; Martin et al., 1996; Josep et al., 1999) 


\subsubsection{Subcellular localization of Brunol1 protein}

We also studied the subcellular localisation of Brunoll protein. For that we have generated GfpBrunoll fusion protein by tagging GFP at $\mathrm{N}$ and $\mathrm{C}$ terminal of Brunoll, respectively (Fig.3.5). Microscopical observation of transiently transfected NIH 3T3 cells emitting a green signal shows that Brunoll is localised in cytoplasm and nucleus (Fig.3.6). Cytoplasmic and nuclear localization of Brunoll suggests that it might be involved in multiple functions within the cell affecting mRNA splicing, polyadenylation, transport, localization, stability, and translation. It has been suggested that Bruno-like protein moves between compartments to regulate both nuclear and cytoplasmic mRNA processing (Good et al., 2000; Ladd et al., 2001) Phylogenetic analysis shows that the Bruno family is closely related to the Hu proteins (Ladd et al., 2001), which contain multiple regions that determine its subcellular localization and contribute to its regulatory function of mRNA stability and translation (Knee et al., 1999). It is very likely that like Hu proteins, subcellular localization of Brunoll is also controlled by a set of elements that collectively drive a balance between a nuclear and cytoplasmic presence.

\subsection{Brunol1 deficient mice are fertile and undergo normal spermatogenesis}

To illustrate the function of the Brunol1 gene in spermatogenesis, we generated knockout mice of Brunol1 by homologous recombination in ES cells. Through Northern blot and RTPCR analysis on total RNA isolated from adult testis and brain, we clearly showed that the Brunol1 transcript was lacking in the Brunol1 ${ }^{-/-}$mice (Fig. 3.9). Thus, the Brunol1 deleted allele is a null mutation and Brunol1 ${ }^{-/}$, is a loss of function mouse model system. The homozygous male and female mice are fertile and we detected no abnormalities in the testicular (Fig 3.12) and brain (Fig 3.14) morphology or histology of Brunol1 deficient mice. To determine whether loss of Brunoll protein affects the properties of the mature sperm, we analyzed various sperm properties of Brunol1 ${ }^{-/-}$mice, for example: morphology, acrosome reaction, motility, and total sperm count in the cauda epididymis

A significant reduction in the total sperm count in Brunol1 ${ }^{-/}$. mice was observed as compared to Brunol1 ${ }^{+/+}$mice (Table 3.3). It suggests that Brunol1 deficiency can affect the normal progression of spermatogenesis thus resulting in reduced number of sperm in Brunol1 $^{-/}$. mice. However, Brunol1 ${ }^{-/}$. mice are fertile with comparable litter size to that of wild type mice. Therefore, this result indicates that the reduced sperm number is although statistically significant but is not enough to affect the fertility of the Brunol1 ${ }^{-/}$. mice. 
From the result of the Brunol1 knockout mice, we can conclude that Brunol1 is not essential for spermatogenesis in mice. As Brunoll is a member of the large Elav/Bruno family of RNA binding proteins, and it is known that different RNA binding proteins regulate posttranscriptional regulation during spermatogenesis, it is very likely that function of Brunol1 was compensated by either another member of Elav/Bruno family or by a similar RNA binding protein. Recently, we found another member of the Elav/Bruno family named Brunol6, which has a very high homology with Brunol1. Interestingly, Brunol6 shows exactly the same pattern of expression like Brunol1 (Fig 3.24). As the expression of Brunol1 in the testis is exactly similar to Brunol6, therefore, there is high probability that Brunol1 and Brunol6 share some function(s) during spermiogenesis. But Northern blot analysis with Brunol6 as a probe, did not detected any significant increase in Brunol6 expression in the Brunol1 $^{-/-}$. mice testis as compared to wild type mice (Fig 3.13). Since Brunol1 and Brunol6 belong to the same family and are highly similar, a minor increase in protein level of Brunol6 can significantly influence its function as a mediator in posttranscriptional regulation pathways; therefore, we cannot rule out that Brunol6 or any other RNA binding protein might compensate the function of the Brunol1 in Brunol1 ${ }^{-/-}$mice.

\subsection{Expression analysis of Brunol4 gene}

Brunol4 gene was cloned and characterized for the first time by Meins et al. (2002). They showed by RT-PCR that expression of Brunol4 starts at $7.5 \mathrm{dpc}$ and continues to later stages of embryogenesis. We confirmed this data and additionally performed RT-PCR on RNA isolated from different stages of embryonic development (unfertilized oocytes, preimplantation and postimplantation stages of embryonic development). By RT-PCR, we could detect the Brunol4 transcript at all the stages of embryonic development, including preimplanatation and postimplanatation stages. Therefore, Brunol4 gene expression starts in unfertilised oocytes and continue to all the later stages of embryonic development (Fig. $3.16 \mathrm{~A}-\mathrm{B}$ ). Expression analysis of Brunol4 in different adult mouse tissues (brain, heart, liver, lung, testis, ovary, muscle and kidney) by Northern blot shows that Brunol4 expression is restricted to brain. However, by RT-PCR, Brunol4 transcript could be detected in ovary also, besides brain (Fig. 3.16 C).

It has been known that several RNA binding proteins expressed during early embryonic development, control early posttranscriptional regulation during embryogenesis. One of the best-characterized examples of a RBP that regulates development is provided by the Bruno 
protein and its role as a translational repressor of oskar mRNA. In Drosophila, oskar is required for formation of germ cells and positioning of the posterior of the embryo (Lehmann and Nüsslein-Volhard, 1996). Both oskar mRNA and the encoded protein must be properly localized to the posterior pole of the oocyte for correct development (Ephrussi and Lehmann, 1992; Kim-Ha et al., 1995). Localized expression of Oskar protein is determined in part by translational silencing of the oskar mRNA outside of the posterior of the oocyte. This repression is mediated by 39 nucleotides long, cis-acting sequences in the untranslated region (UTR) of oskar mRNA called Bruno response elements (BREs), and a corresponding trans-acting factor, the Bruno protein (Fig 4.3). By regulating the localized expression of Oskar, Bruno has a key role in germ cell formation and early embryogenesis.

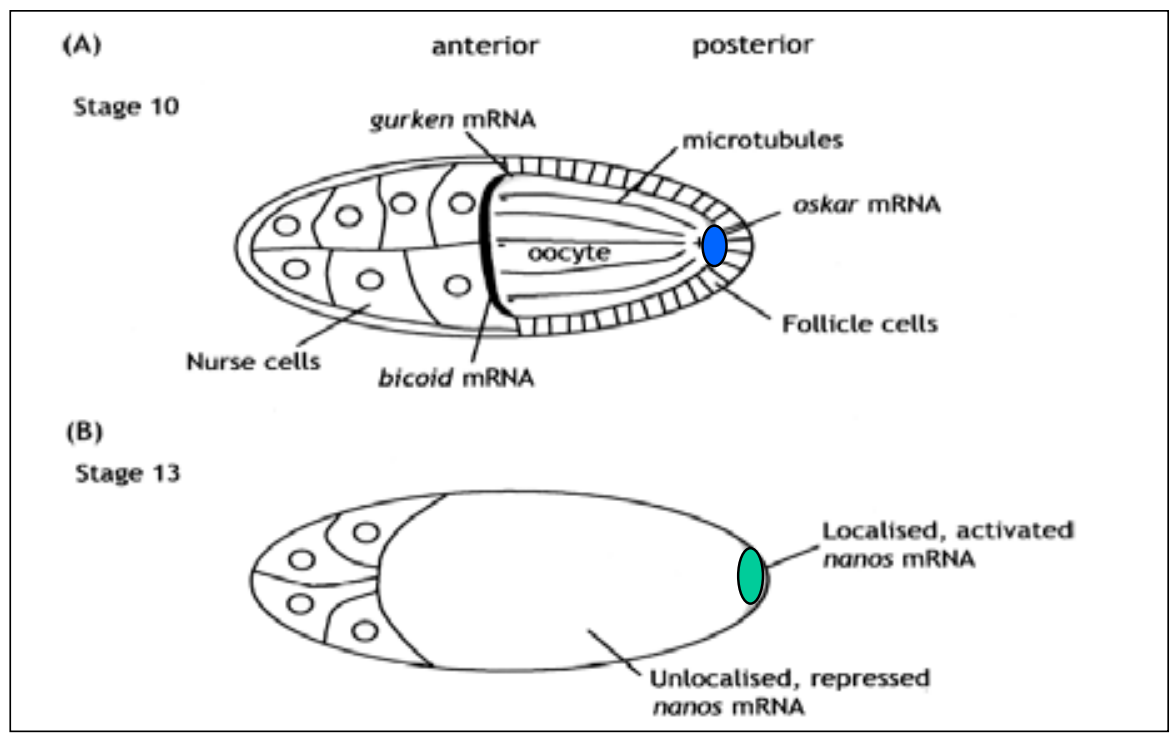

Fig 4.3 Localization of Drosophila mRNAs during oogenesis. (A) In stage 10 oocytes, oskar mRNA is localized to the posterior pole, bicoid to the anterior pole and gurken to the anterior-dorsal corner. Microtubules are oriented with their plus ends toward the posterior, allowing directional transport to occur (Theurkauf et al., 1992). (B) In stage 13 oocytes, a proportion of nanos mRNA has become localized to the posterior pole, in addition to the previously localized mRNA. Localised nanos mRNA is translationally activated while the majority of nanos mRNA, which is not localized, remains repressed (Bergsten and Gavis, 1999). 
Another example of RNA binding protein, Embryo deadenylation element binding protein (EDBEN), a homolog of Bruno identified in Xenopus laevis, has been shown to regulate mRNA deadenylation in early embryonic development (Paillard et al., 1998).

Interestingly, most of the members of Elav/Bruno family show early embryonic expression, which is later on restricted to brain. So, here a question arises that what is common between early embryonic development and brain. Elav is the family of RNA binding proteins and it is well known that RNA binding proteins play a crucial role in posttranscriptional regulation of maternally stored RNA until zygotic genome activation occurs. One of the mechanisms of posttranscriptional regulation is polyadenylation, which is characterized in lower animals. It is known that EDBEN (elav) protein regulates early polyadenylation in early embryo of Xenopus. Although cytoplasm polyadenylation is a hallmark of early metazoan development, there is virtually no evidence that it occurs in adult tissues. From a teleological point of view, this would seem very inefficient. That is, a significant genetic load is used to regulate translation by cytoplasmic polyadenylation, so in the last few years, mounting evidence has suggested that the brain might contain dormant mRNAs. In particular, specific mRNAs are present in dendrites (Crino et al., 1996; Steward et al., 1997), and synaptic spines (regions at the bases of synapses) have ribosomes and translation initiation factors (Steward and Levy, 1982). Most importantly, recent studies indicate that translational control in dendrites may be important for long-term changes in synaptic efficacy. Kang et al. (1996) and Wu et al.(1998) determined that CPEB is a factor present in the brain that regulates cytoplasmic polyadenylation. Although CPEB expression is quite restricted in the mouse (Gebauer and Richter, 1996), brain tissue contains readily detectable amounts. Furthermore, CPEB is present in the dendritic layers of the hippocampus, at synapses in cultured hippocampus neurons, and in postsynaptic densities (i.e., large networks of structural and regulatory proteins immediately beneath the postsynaptic membrane) of adult brain (Wu et al., 1998). One mRNA, which is present in dendrites and known to be essential for the long-lasting phase of long-term potentiation (LLTP) encodes Ca21-calmodulin-dependent protein kinase II (a-CaMKII). The 39 UTR of CaMKII mRNA contains UUUUUAU-type CPEs, which bind CPEB in vitro and drive polyadenylation-induced translation in injected Xenopus oocytes. This data demonstrate that this process also occurs in the brain. By assuming the phylogenetic conservation of Brunol4 with EDBEN of Xenopus, it might be possible that Brunol4 also controls the 
crucial regulation of dormant mRNA of neurons. Although to explain the exact mechanistic role of Brunol4, it is necessary to identify the target mRNA of Brunol4.

It is also known that neurons use various means to regulate posttranscriptional gene expression, including alternative splicing, RNA transport, local translation and RNA editing. Neural RNA-binding proteins are likely to play an essential role in mediating this regulation (Timchenko et al., 1996). The Mammalian ELAV-like neuronal RNA-binding proteins, $\mathrm{HuB}$ and $\mathrm{HuC}$, phylogenetically related to Bruno, promote neuronal development in both the central and the peripheral nervous systems (Ladd et al., 2004). Based on phylogenetic relation of Brunol4 with $\mathrm{Hu}$ protein and its expression being restricted to brain, it is more likely that Brunol4 also play important role in brain development.

\subsection{Functional analysis of Brunol4 gene by generation of Brunol4 deficient mice}

\subsubsection{Generation of Brunol4 knockout mice}

To elucidate the role of the Brunol4 gene, we decided to generate knockout mice for the Brunol4 gene. A region of 800 bp of exon1 including ATG was replaced by GFP/Neo cassette. To generate the knockout construct of Brunol4, a $3.8 \mathrm{~kb} 5^{\prime}$ arm and a $5.3 \mathrm{~kb} 3^{\prime}$ arm were cloned into pTKNeo targeting vector and the gene was replaced with a GFP/Neo cassette (Fig 3.18). The targeting vector was transfected into the ES cells and out of $400 \mathrm{ES}$ clones only one positive recombinant clone was obtained. The positive clone was injected into blastocysts. Four chimeras: 5\%,2x15\% and 25\% were obtained. All the four chimeras were bred with $\mathrm{C} 57 \mathrm{BL} / 6 \mathrm{~J}$ mice, to obtain $\mathrm{F} 1$ animals in $\mathrm{C} 57 \mathrm{BL} / 6 \mathrm{~J}$ background. Germ line transmission was detectable only by one $25 \%$ chimera after three and half month of breeding. Only two brown mice were obtained The germ line transmission of the mutant allele was verified by genomic PCR (Fig 3.18 C). While Brunol4 heterozygous mice were apparently healthy and fertile, no Brunol4 homozygous mice were identified. This result revealed that homozygous embryos might be lethal. To determine the stage when development of homozygous embryos is arrested, a detailed analysis of embryos at different stages of embryonic development, including up to one-cell stage embryos was done. But Brunol4 homozygous mutants could not be identified by genotyping (PCR and Southern Blot). These results indicate that there might be two copies/duplication of Brunol4 gene. 


\subsubsection{Murine Brunol4 is present in more than one copy}

We could not identify the Brunol4 homozygous mice by conventional genotyping (PCR and Southern blot). The analysis of Brunol4 transcript in heterozygous mice by Northern blot also showed that there is no reduction of Brunol4 transcript as compared to wild type. These results indicated that there might be Brunol4 homozygous mice among Brunol4 heterozygous mice but we cannot identify them by genotyping. Then, breeding strategy was used to identify the homozygous mice among Brunol4 heterozygous mice. To identify the Brunol4 homozygous mice, fifteen Brunol4 so called heterozygous mice were bred with wild type and the offspring of all the fifteen breeding pairs were genotyped by PCR. Interestingly, we found four pairs among these fifteen breeding pairs, which gave only heterozygous offspring (Table 3.8). So it is clear that the four parents, which gave all heterozygous offspring after breeding with wild type, are Brunol4 homozygous mice. Further, these homozygous mice were analysed by Northern Blot analysis but there was no difference in Brunol4 transcript compared to wild type (Fig 3.22).

To further prove that there are two or more copies of Brunol4, we performed Southern blot analysis of $129 / \mathrm{Sv}$ mice genomic DNA digested by different restriction enzymes. Southern blot analysis showed only one signal with each restriction enzyme similarly like single copy gene. This result indicates that Brunol4 is a recently duplicated gene with very similar or even identical sequences.

To investigate whether multiple copies of Brunol4 gene are transcribed in mice, RT-PCR experiment was performed using adult mouse brain RNA. Resulting PCR products were cloned into pGEM-T Easy vector. Fifty independent clones were sequenced and all of them showed the same sequence. This result suggests that only one copy of Brunol4 is transcribed or all possible copies of Brunol4 gene have the same sequence so that we could not differentiate between them by sequencing. Taking all the above observations together suggest that there are more than one copy of Brunol4 gene and the one, which is not transcribed, was deleted in our homologous recombination

In literature, a number of genes are known for duplication. Bolcun et al. (2003) reported duplication of murine testase 2 (ADAM 25). They found two different restriction patterns of subcloned fragments of the gene, indicating the presence of two different testase 2 transcripts. Celera database searches demonstrated that the two transcripts are the products of two testase 2 genes, which are located on mouse chromosome 8 in close 
distance of $24 \mathrm{~kb}$. They show high sequence similarity to the published testase 2 gene ( 87.8 and $95.5 \%$, respectively).

In our case extensive search of NCBI database did not show extra copy of Brunol4. A similar case was reported in case of murine Tcte3. Huw et al. (1995) suggested that Tcte3 exists in multiple copies, which are clustered in tandem array in the mouse genome. However, in the database, the sequence of only one gene is indicated (accession number: NT_039641).

It might be possible that the duplication of Brunol4 gene occurred in recombinant ES cell clone, which we used for blastocyst injection. Unfortunately, we had only one positive clone so we could not confirm the ES cell derived duplication by using other independent ES cell clones for generating Brunol4 knockout mice. Although, we again transfected the Brunol4 knockout construct into ES cell to find other Brunol4 recombinant ES cell clones and 280 ES cell clones were screened by Southern blot, none of them was recombinant. To answer all the open questions about possible Brunol4 duplication, further recombinant ES cell clones of Brunol4 must be identified.

\subsection{Activation of Brunol4 gene in preimplantation embryonic development}

Our study of Brunol4 expression by RT-PCR during early embryonic development shows that Brunol4 transcript is present at all stages of embryonic development (Fig 3.16A-B), including preimplantation and postimplanatation stages. As we could also detect the Brunol4 transcript in unfertilised oocytes, so it might be possible that at two-cell stage we amplified the maternally stored transcript of Brunol4 instead of newly synthesised transcript. It is known that in Drosophila and Xenopus, mRNAs stockpiled in the oocytes are stable after fertilization and regulate many aspects of embryonic development (Wolpert et al., 2002). Conversely, in mammals, oocyte derived mRNAs are degraded shortly after fertilization and cannot direct more than the first few cell divisions (Thompson et al., 1998). Therefore, zygotic genome activation (ZGA) must occur very early during mammalian development. (Fig 4.4) 

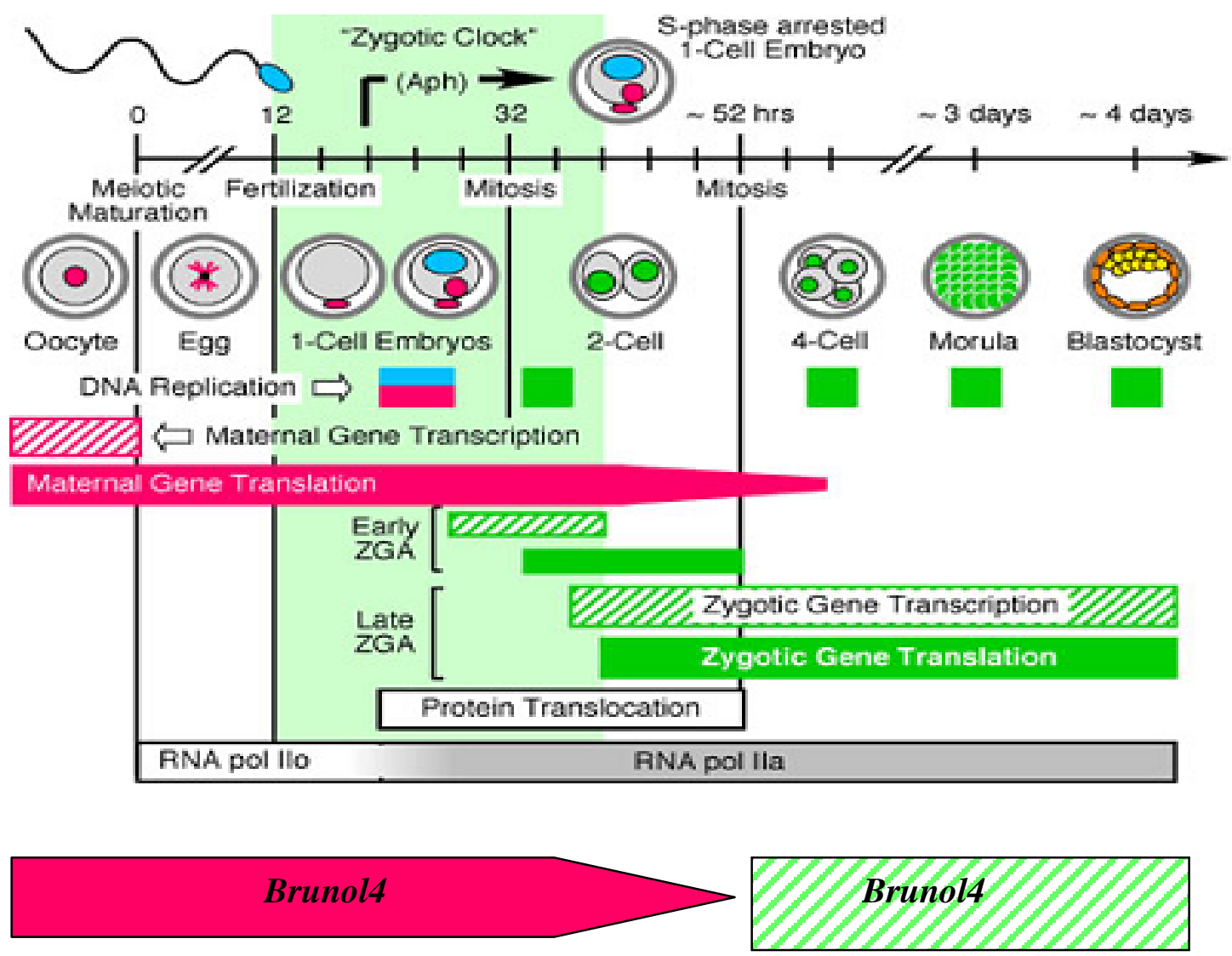

Figure 4.4. Maternal to zygotic gene transition in the mouse. Maternal events are indicated in RED, paternal events in BLUE, and zygotic events in GREEN. Open bars apply to both. Embryonic stem cells ("inner cell mass") are indicated in yellow; trophectodermal cells in orange. Periods of transcription are indicated by hatched bars; translation by solid bars.

To differentiate between the maternally derived transcript and newly synthesised transcript of Brunol4 at two-cell stage, we exploited the single base polymorphism present at 3' UTR of Brunol4 cDNA in different strains of mice (Fig 3.26). Our study for Brunol4 transcript shows that at two-cell stage only maternal transcript was present (Fig 3.28). At 4cell stage of embryonic development we observed both maternally and paternally derived transcript (Fig 3.29A). It means the ZGA of Brunol4 occurs at 4-cell stage. Interestingly at 4-cell stage paternally derived allele was expressed preferentially (Fig 3.29B) 
It is known that transcription from the embryonic genome occurs at roughly the 2-cell stage in mice, 4- to 8-cell stage in humans and the 8- to 16- cell stage in cattle (Telford et al., 1990; Memili and First, 2000). In mouse, a minor burst of ZGA towards the end of the one-cell stage is followed by a major burst during the two-cell stage (Latham et al., 1992; Vernet et al., 1992; Aoki et al., 1997; Thompson et al., 1998; Schultz, 2002). ZGA is required for continued development because mRNAs common to the oocyte and embryo (e.g., genes involved in the maternal- to-zygotic transition and housekeeping genes) are replenished and many genes not transcribed in the oocyte are expressed for the first time. The outcome of ZGA is a novel gene expression profile that establishes the totipotent state of each blastomere in the cleavage stage embryo. This step is a prerequisite for future cell lineage commitments and differentiation events that underlie pattern formation and organogenesis. Changes in chromatin structure are thought to play an important role in reprogramming gene expression during ZGA (Schultz and Worrad, 1995; Thompson et al., 1998; Kanka, 2003).

Indeed, in mammals zygotic genome activation (ZGA) occurs synchronously and till now there is no report about asynchronous ZGA. Asynchronous activation of parental alleles was reported only in interspecific hybrids and not in heterozygotes within the same species. Developmental analyses of interspecific hybrids frequently reveal perturbations of gene function. The relatively delayed expression of paternal allelic isozymes has been observed for chicken-quail hybrids (Castro-Sierra and Ohno, 1968; Meyerhof and Haley, 1975) and for interspecific hybrids of trout (Hitzeroth et al., 1968; Goldberg et al., 1969; Schmidtke et al., 1976; Yamauchi and Goldberg, 1974; Wright et al., 1975). Although many interspecific hybrids manifest preferential inhibition of the paternally derived alleles, the analyses of some F1 hybrids have revealed the selective repression of maternal allele expression and the expression of the paternal alleles (Pipkin and Bremner, 1970; Whitt et al, 1972, 1973a; Vrijenhoek, 1975). These observations suggest that a specific repression of either maternal or paternal alleles may occur in some interspecific hybrids. During the development of hybrids between closely related species, one would expect to detect little or no allelic asynchrony or inhibition (Ohno, 1969). If such is the case, the egg cytoplasm might have a role in recognizing individual gene loci within the zygotic nuclei and activating them at appropriate stages of development. Two alleles within the same species are expected to have a nearly identical base sequence, the difference being a few base substitutions. Thus, the egg cytoplasm would be able to recognize a paternally derived 
allele and a maternally derived allele of the heterozygote equally well. In the case of interspecific hybrids, on the other hand, a paternally derived allele from the alien species can have a base sequence considerably different from that of the maternally derived allele. Consequently, the egg cytoplasm might have difficulty in recognizing an alien allele. This phenomenon of preferential activation of maternally derived alleles might fall into the general category of nuclear-cytoplasmic incompatibility. 


\section{SUMMARY}

The subject of this study was the expression and functional analysis of two novel genes of Elav/Bruno RBPs family, namely Brunol1 and Brunol4. Brunol1 was described for the first time (Wilhelm et al., 2001) in a systematic search for genes responsible for neurodegenerative diseases. Expression analysis of Brunol1 by RT-PCR during embryonic development shows that its expression starts at $9.5 \mathrm{dpc}$. In adult mouse, the Brunol1 expression is restricted to brain and testis. Expression of Brunol1 was also observed in testes developmental mutants. Brunol1 transcript was detectable in Leyl-/-, olt/olt and $\mathrm{qk} / \mathrm{qk}$ mutant but not in $\mathrm{W} / \mathrm{W}^{\mathrm{V}}$. and $\mathrm{Tfm} / \mathrm{y}$ mutants. This implies that Brunol1 expression is restricted to the germ cells and not in other cell types of testis and its expression starts at spermatocyte stage. Subcellular localisation of Brunoll protein tagged with GFP shows that Brunoll protein is localized in both cytoplasm and nucleus. For the functional analysis, knockout mice for Brunol1 were generated on C57 BL/6J x 129/Sv and 129/Sv backgrounds. Males from both backgrounds were fertile, but the number of sperms in cauda epididymis was reduced as compared to the wild type. Statistically reduced motility and progressive movement of sperms on both backgrounds was also observed in comparison to wild type. Spermatozoa showed normal acrosome reaction. Histological sections of brain and testes of homozygous mice revealed no abnormalities in cellular type or cellular structure. From these data it can be concluded that Brunol1 may not be essential for embryonic viability, spermatogenesis and development of neural tissue.

In the second part of this study, expression and function of Brunol4 was analysed. This gene was described for the first time by Meins et al. (2002), as a brain specific gene. By Northern blot analysis, Brunol4 expression was found to be restricted to brain only. By RTPCR, the expression of Brunol4 was observed in brain, ovary and at all the stages of embryonic development including preimplantation and postimplantation stages. For the functional analysis, knockout mice for Brunol4 were generated. While Brunol4 heterozygous mice were apparently healthy and fertile, no Brunol4 homozygous mice were identified. This result revealed that homozygous embryos might be lethal. To determine the stage when development of homozygous embryos is arrested, a detailed analysis of embryos at different stages of development, including up to one-cell stage embryos was done, but no Brunol4 homozygous mutant was found. To identify the Brunol4 homozygous mice among heterozygous mice by breeding strategy, fifteen Brunol4 so-called heterozygous mice were bred with wild type and the offspring of all the fifteen breeding 
pairs were genotyped by PCR. Four pairs among these fifteen breeding pairs gave all heterozygous offspring and it was then clear that they are Brunol4 homozygous mice. These results clearly indicated that there are in fact Brunol4 homozygous mice among heterozygous but they could not be identified by genotyping. Further, these homozygous mice were analysed by Northern Blot but there was no difference in Brunol4 transcript compared to wild type. To investigate whether multiple copies of Brunol4 gene are transcribed in mice, RT-PCR experiment was performed and sequencing results of 15 independent PCR products showed that only one copy of Brunol4 is transcribed. So the present study shows that there are more than one copy of Brunol4 gene and the one, which is not transcribed, was deleted. It might also be possible that the possible duplication of Brunol4 gene was derived from recombinant ES cell clone, which was used for generation of Brunol4 knockout mouse. Retransfection of the Brunol4 knockout construct into ES cells yielded no recombinant ES cell clone. To solve the puzzle about possible Brunol4 duplication, further recombinant ES cell clones for Brunol4 must be identified.

In the third part of this study we identified Brunol6 as a novel member of elav/Bruno family. Expression of Brunol6 was analysed during embryonic development and in adult tissues. During embryonic development, expression of Brunol6 starts at $9.5 \mathrm{dpc}$ and continue to the later stages of embryonic development while in adult mouse tissues Brunol6 expression is restricted to brain and testis. Expression of Brunol6 was also observed in testes developmental mutants. Brunol6 transcript was detectable in Leyl-/-, olt/olt and $\mathrm{qk} / \mathrm{qk}$ mutant but not in $\mathrm{W} / \mathrm{W}^{\mathrm{V}}$. and $\mathrm{Tfm} / \mathrm{y}$ mutants.

Finally we studied the activation of mouse Brunol4 gene during early embryonic stages. Our study shows that at two-cell stage of embryonic development only maternal transcript storage of Brunol4 is present. Zygotic activation of Brunol4 gene transcript starts at 4-cell stage of embryonic development. Interestingly it was found that at 4-cell stage the paternal allele of Brunol4 is expressed preferentially. 


\section{REFERENCES}

Akamatsu W., Okano H. J., Osumi N., Inoue T., Nakamura S., Sakakibara S., Miura M., Matsuo, Burd C.G., Dreyfuss G. (1994) Conserved structures and diversity of functions of RNA-binding proteins. Science. 265: 615-621.

Antic D., Keene J.D. (1997) Embryonic lethal abnormal visual RNA-binding proteins involved in growth, differentiation, and posttranscriptional gene expression. Am J Hum Gen. 61: 273-278.

Antic D., Keene J. D. (1998) Messenger ribonucleoprotein complexes containing human ELAV proteins: interactions with cytoskeleton and translational apparatus. J Cell Sci. 111: 183-197.

Antic D., Lu N., Keene J. D. (1999) ELAV tumor antigen, Hel-N1, increases translation of neurofilament M mRNA and induces formation of neurites in human teratocarcinoma cells. Genes Dev. 13: 449-461.

Aoki F., Worrad D.M., Schultz R.M. (1997) Regulation of transcriptional activity during the first and second cell cycles in the preimplantation mouse embryo. Dev Biol. 181: 296307.

Ausubel F.M., Brent R., Kingston R.E., Moore D.D., Seidman J.G., Smith J.A., Struhl K. (1994) Current protocols in molecular biology. John Wiley \& Sons Inc., USA.

Bachinski, D. L., Roberts, L.L.R. (2001) Genomic organization and isoformspecific tissue expression of human NAPOR (CUGBP2) as a candidate gene for familial arrhythmogenic right ventricular dysplasia. Genomics 74: 396-401.

Balhorn R., Weston S., Thomas C., Wyrobek A. J. (1984) DNA packaging in mouse spermatids. Synthesis of protamine variants and four transition proteins. Exp Cell Res. 150: 298-308. 
Birney E., Kumar S., Krainer A. R. (1993) Analysis of the RNA-recognition motif and RS and RGG domains: conservation in metazoan pre-mRNA splicing factors. Nucleic Acid Res. 21: 5803-5816

Bolcun E., Rzymski T., Nayernia K., Engel W. (2003) ADAM family genes testase 2alpha and 2 beta are chromosomally linked and simultaneously expressed in male germ cells. Mol Reprod Dev. 65 (1): 19-22.

Bradford M.M. (1976) A rapid and sensitive method for the quantitation of microgram quantities of protein utilizing the principle of protein-dye binding. Anal Biochem. 72: 248254.

Braun R. E. (1998) Post-transcriptional control of gene expression during spermatogenesis. Semin Cell Dev Biol. 9: 483-489.

Burd C. G., Dreyfuss G. (1994) Conserved structures and diversity of functions of RNAbinding proteins. EMBO J. 13: 1197-1204.

Castro-Sierra E., Ohno S. (1968) Allelic inhibition at the autosomally inherited gene locus for liver alcohol dehydrogenase in chicken-quail hybrids. Biochem Genet. 1:323.

Chien A., Edgar D.B., Trela J.M. (1976) Deoxyribonucleic acid polymerase from the extreme thermophile Thermus aquaticus. J Bacteriol. 127: 1550-1557.

Chomczynski P., Sacchi N. (1987) Single-step method of RNA isolation by acid guanidinium thiocyanate-phenol-chloroform extraction. Anal Biochem. 162: 156-159.

Clark J.M. (1988) Novel non-templated nucleotide addition reactions catalyzed by procaryotic and eucaryotic DNA polymerases. Nucleic Acids Res. 16: 9677-9686.

Connor F., Wright E., Denny P., Koopman P. and Ashworth A. (1995) The Sryrelated HMG box-containing gene Sox6 is expressed in the adult testis and developing nervous system of the mouse. Nucleic Acids Res. 23: 3365-72. 
Costa G.L. and Weiner M.P. (1994) Polishing with T4 or Pfu polymerase increases the efficiency of cloning of PCR fragments. Nucleic Acids Res. 22: 2423.

Crino P. B. and Eberwine J. (1996) Molecular characterization of the dendritic growth cone: regulated mRNA transport and local protein synthesis. Neuron. 17:1173-1187.

Dalmau J., Gultekin S. H., Voltz R., Hoard R., Champs T. D., Balmaceda C., Batchelor T., Gerstner E., Eichen J., Frennier J., Posner J. B., Rosenfeld M. R. (1999)Ma1, a novel neuron- and testis-specific protein, is recognized by the serum of patients with paraneoplastic neurological disorders. Brain. 122 (1): 27-39

David G., Abbas N., Stevanin G., DuÈrr A., Yvert G., Cancel G. (1997) Cloning of the SCA7 gene reveals a highly unstable CAG repeat expansion. Nature Genet. 17: 65-70.

Denhardt D.T. (1966) A membrane-filter technique for the detection of complementary DNA. Biochem Biophys Res Commun. 23: 641-646.

Devos D., Schraen-Maschke S., Vuillaume I., Dujardin K., Naze P., Willoteaux C. (2001) Clinical features and genetic analysis of a new form of spinocerebellar ataxia. Neurology. 56: $234-8$.

Ding J., Hayashi M. K., Zhang Y., Manche L., Krainer A. R., Xu, R. M. (1999) article Crystal structure of the two-RRM domain of hnRNP A1 (UP1) complexed with singlestranded telomeric DNAGenes Dev. 13:1102-1115.

Ebersole T. A., Chen Q., Justice M. J., Artzt K. (1996) The quaking gene product necessary in embryogenesis and myelination combines features of RNA binding and signal transduction proteins. Nat Genet. 12: 260-265.

Ephrussi A., and Lehmann R. (1992) Induction of germ cell formation by oskar. Nature. 358: 387-392. 
Fajardo M. A., Haugen H. S., Clegg C. H., Braun R. E. (1997) Separate elements in the 3' untranslated region of the mouse protaminelmRNA regulate translational repression and activation during murine spermatogenesis. Dev Biol. 191: 42-52.

Feinberg A. P., Vogelstein B. (1989) A technique for radiolabeling DNA restriction endonuclease fragments to high specific activity. Anal Biochem. 123: 6-13.

Gebauer F., Richter J. D. (1996) Mouse cytoplasmic polyadenylation element binding protein: an evolutionarily conserved protein that interacts with the cytoplasmic polyadenylylation elements of c-mos mRNA. Proc Natl Acad Sci. USA 93: 14602-14607.

Gershoni J. M., Palade G.E. (1982) Electrophoretic transfer of proteins from sodium dodecyl sulfate-polyacrylamide gels to a positively charged membrane filter. Anal Biochem. 124: 396-405.

Giorgini F., Davies H. G., Braun R. E. (2001) MSY2 and MSY4 bind a conserved sequence in the $3^{\prime}$ untranslated region of protamine 1 mRNA in vitro and in vivo. Mol Cell Biol. 21: 7010-7019.

Good P. J. (1997) The role of elav-like genes, a conserved family encoding RNA-binding proteins, in growth and development. Semin Cell Dev Biol. 8: 577-584 32.

Good P. O., Chen S., Warner, Herring D. (2000) A family of human RNA-binding proteins related to the Drosophila Bruno translational regulator. J Biol Chem. 275: 28583-28592.

Hitzeroth H., Klose J., Ohno S., Wolf U. (1968) Asynchronous activation of parental alleles at the tissue-specific gene loci observed on hybrid trout during early development. Biochem Genet. 1: 287.

Hodge R. (1994) Preparation of RNA gel blots. Methods Mol Biol. 28: 49-54.

Huw L.Y., Goldsborough A.S., Willison K., Artzt K. (1995) Tctex2: a sperm tail surface protein mapping to the t-complex. Dev Biol. 170:183-194. 
Jain R. G., Andrews L. G., McGowan K. M., Pekala P. H., and Keene J. D. (1997) Ectopic expression of Hel-N1, an RNA-binding protein, increases glucose transporter (GLUT1) expression in 3T3-L1 adipocytes. Mol Cell Biol. 17: 954-962.

Joyner A. L. (2000) Gene Targeting. 2nd Edition., A Practical Approach. pp: 138. Oxford University Press, New York.

Kang H., Schuman E. M. (1996) A requirement for local protein synthesis in neurotropininduced hippocampal plasticity. Science. 273:1402- 1406.

Kanka J. (2003) Gene expression and chromatin structure in the pre-implantation embryo. Theriogenology. 59: 3-19.

Kasashima K., Terashima K., Yamamoto K., Sakashita E., Sakamoto H. (1999) Cytoplasmic localization is required for the mammalian ELAV-like protein HuD to induce neuronal differentiation. Genes Cells. 4: 667-683.

Kleene K. C., Distel R. J., Hecht N. B. (1984) Translational regulation and deadenylation of a protamine mRNA during spermiogenesis in the mouse. Dev Biol. 105: 71-79.

Knecht A. K., Good P. J., Dawid I. B., Harland R. M. (1995) Dorsal-ventral patterning and differentiation of noggin-induced neural tissue in the absence of mesoderm. Development. 121: $1927-1936$.

Ladd A.N., Cooper B.T. (2001) The CELF family of RNA binding proteins is implicated in cell-specific and developmentally regulated alternative splicing. Mol Cell Biol. 21: 12851296.

Ladd A.N., Nguyen N.H., Malhotra K., Cooper T.A. (2004) CELF6, a member of the CELF family of RNA-binding proteins, regulates muscle-specific splicing enhancerdependent alternative splicing. J Biol Chem. 279: 17756-1776. 
Laemmli U.K. (1970) Cleavage of structural proteins during the assembly of the head of the bacteriophage T4. Nature. 227: 680-685.

Laird P.W., Zijderveld A., Linders K., Rudnicki M.A., Jaenisch R., Berns A. (1991) Simplified mammalian DNA isolation procedure. Nucleic Acids Res. 19: 4293.

Latham K.E., Latham D., Solter R.M. (1992) Acquisition of a transcriptionally permissive state during the 1-cell stage of mouse embryogenesis. Dev Biol. 149: 457-462.

Lee K., Fajardo M.A., Braun R.E. (1996) A testis cytoplasmic RNA-binding protein that has the properties of a translational repressor. Mol Cell Biol. 16: 3023-3034.

Lehmann R., Nüsslein-Volhard C. (1986) Abdominal segmentation, pole cell formation, and embryonic polarity require the localized activity of oskar, a maternal gene in Drosophila. Cell. 47: 141-152.

Lie Y. S., Macdonald P. M. (1999) Translational regulation of oskar mRNA occurs independent of the cap and poly (A) tail in Drosophila ovarian extracts. Development. 126: 4989-4996.

Lundquist E. A., Herman R. K., Rogalski T. M., Mullen G. P., Moerman D. G., Shaw, J. E. (1996) The mec-8 gene of C. elegans encodes a protein with two RNA recognition motifs and regulates alternative splicing of unc-52 transcripts. Development. 122: 1601-1610.

Macknight R., Bancroft I., Page T., Lister C., Schmidt R., Love K., Westphal L., Murphy G. N., Darnell R. B., Okano H. (1999) FCA, a gene controlling flowering time in Arabidopsis, encodes a protein containing RNA-binding domains. Proc Natl Acad Sci. U. S. A. 96: 9885-9890.

Mali P., Kaipia A., Kangasniemi M., Toppari J., Sandberg M., Hecht N. B., Parvinen, M. (1989) Stage-specific expression of nucleoprotein mRNAs during rat and mouse spermiogenesis. Reprod Fertil Dev. 1: 369-382. 
Markert C., Vrijenhoek R. C. (1975) Gene dosage in diploid and triploid unisexual fishes (Poeciliopsis Poeciliidae). Genetics and Evolution In: Isozymes. Vol. 4: 463475.

Martin G.R. (1981) Isolation of a pluripotent cell line from early mouse embryos cultured in medium conditioned by teratocarcinoma stem cells. Proc Natl Acad Sci USA.78: 76347638.

Martin J.H., Mohit A.A., Miller C.A. (1996) Developmental expression in the mouse nervous system of the $\mathrm{p} 49^{3 \mathrm{~F} 12}$ SAP kinase. Mol Brain Res. 35: 47-57.

Meins M., Schlickum S., Wilhelm C., Missbach J., Glaser B., Grzmil M., Burfeind P., Laccone F. (2002) Identification and characterization of murine Brunol4, a new member of the elav/bruno family. Cytogenet Genome Res. 97 (3-4): 254-60.

Memili E., First N.L. (2000) Zygotic and embryonic gene expression in cow: a review of timing and mechanisms of early gene expression as compared with other species. Zygote 8: 87-96.

Merrill B. M., Stone K. L., Cobianchi F., Wilson S. H., Williams K. R. (1988) Phenylalanines that are conserved among several RNA-binding proteins form part of a nucleic acid-binding pocket in the A1 heterogeneous nuclear ribonucleoprotein. $J$ Biol Chem. 263: 3307-3313.

Nagai K., Oubridge C., Ito N., Avis J., Evans P. (1995) The RNP domain: a sequencespecific RNA-binding domain involved in processing and transport of RNA. Trends Biochem. Sci. 126: 4989-4996.

Nakamura K., Jeong S.Y., Uchihara T., Anno M., Nagashima K., Nagashima T. (2001) SCA17, a novel autosomal dominant cerebellar ataxia caused by an expanded polyglutamine in TATA-binding protein. Hum Mol Genet. 10: 1441-8. 
Noce T., Fujiwara Y., Ito M., Takeuchi T., Hashimoto N., Yamanouchi M. (1993) A novel murine zinc finger gene mapped within the tw18 deletion region expresses in germ cells and embryonic nervous system. Dev Biol. 155: 409-22.

Ohno S. (1969) The preferential activation of maternally derived alleles in development in interspecific hybrids. Wistar Inst Symp Monogr. 9:137.

Orr H.T., Chung M.Y., Ban S., Kwiatkowski T.J., Servadio J., Beaudet A. (1993) Expansion of an unstable trinucleotide CAG repeat in spinocerebellar ataxia type 1. Nature Genet. 4: 221-227.

Paillard L. F., Omilli V., Legagneux T., Bassez D., Maniey H.B. (1998) EDEN and EDEN$\mathrm{BP}$, a cis element and an associated factor that mediates sequence-specific mRNA deadenylation in Xenopus embryos. EMBO J. 17: 278-287.

Perez I., McAfee J. G., Patton J. G. (1997) Multiple RRMs contribute to RNA binding specificity and affinity for polypyrimidine tract binding protein. Biochemistry. 36: 1188111890.

Perron M., Furrer,M. P., Wegnez M., Theodore L. (1999) Misexpression of the RNAbinding protein ELRB in Xenopus presumptive neurectoderm induces proliferation arrest and programmed cell death. Int J Dev Biol. 43: 295-303.

Pipkin S. B., Bremner T. A. (1970) Aberrant octanol dehydrogenase isozyme patterns in terspecific Drosophila hybrids. J Exp ZooL. 175: 283.

Pontius B. W., Berg P. (1990) Renaturation of Complementary DNA Strands Mediated by Purified Mammalian Heterogeneous Nuclear Ribonucleoprotein A1 Protein: Implications for a Mechanism for Rapid Molecular Assembly Proc Natl Acad Sci. U. S. A. 87: 84038407.

Richter K. H., Grunz I. B., Dawid. (1988) Gene expression in the embryonic nervous system of Xenopus laevis. Proc Natl Acad Sci. USA. 85: 8086-8090. 
Saiki R.K., Gelfand D.H., Stoffel S., Scharf S.J., Higuchi R., Horn G.T., Mullis K.B., Erlich H.A. (1988) Primer directed enzymatic amplification of DNA with a thermostable DNA polymerase. Science. 239: 487-91.

Sanger F., Nicklen S., Coulson A.R. (1977) DNA sequencing with the chain terminating inhibitors. Proc Natl Acad Sci U S A. 74: 5463-5467.

Sanpei K., Takano H., Igarashi S., Sato T., Oyake M., Sasaki H. (1996) Identification of the spinocerebellar ataxia type 2 gene using a direct identification of repeat expansion and cloning technique. Nature Genet. 14: 277-84.

Schmidtke J., Kuhl P., Engel W. (1976) Transitory hemizygosity of paternally derived alleles in hybrid trout embryos. Nature. 25, 260(5549):319-20.

Schultz R. M. (2002) The molecular foundations of the maternal to zygotic transition in the preimplantation embryo. Hum Reprod Update. 8: 323-331.

Serin, G., Joseph, G., Ghisolfi, L., Bauzan, M., Erard, M., Amalric, F., and Bouvet, P. (1997) 13116Two RNA-binding Domains Determine the RNA-binding Specificity of Nucleolin J. Biol. Chem. 272:13109.

Shamoo Y., Abdul-Manan N., Williams K. R. (1995) Multiple RNA binding domains (RBDs) just don't add up. Nucleic Acids Res. 23: 725-728.

Siomi H., Dreyfuss G. (1995) A nuclear localization domain in the hnRNP A1 protein. $J$ Cell Biol. 129: 551-560.

Siomi H., Dreyfuss G. (1997) RNA-binding proteins as regulators of gene expression. Curr Opin Genet Dev. 7: 345-353.

Soong B.W., Lu Y.C., Choo KB., Lee H.Y. (2001) Frequency analysis of autosomal dominant cerebellar ataxia in Taiwanese patients and clinical and molecular characterization of spinocerebellar ataxia type 6. Arch Neurol. 58: 1105-1125. 
Southern E. M. (1975) Detection of specific sequences among DNA fragments separated by gel electrophoresis. J Mol Biol. 98: 503-517.

Steward O. (1997) mRNA localization in neurons: a multipurpose mechanism. Neuron 18: 9-12.

Steward O., Levy W. B. (1982) Preferential localization of polyribosomes under the base of dendritic spines in granule cells of the dentate gyrus. J Neurosci. 2: 284-291.

Suzuki H., Jin Y., Otani H., Yasuda K., Inoue K. (2002) Regulation of alternative splicing of alpha-actinin transcript by Bruno-like proteins. Genes Cells 7:133-141.

Takano H., Cancel G., Ikeuchi T., Lorenzetti D., Mawad R., Stevanin G. (1998) Close associations between prevalence of dominantly inherited spinocerebellar ataxias with CAGrepeat expansions and frequencies of large normal CAG alleles in Japanese and Caucasian populations. Am J Hum Genet. 63: 1060-1066.

Telfort N.A., Watson A.J., Schultz G.A. (1990) Transition from maternal to embryonic control in early mammalian development: a comparison of several species. Mol Reprod Dev. 26:90-100.

Thompson E.M., Legouy E., Renard J.P. (1998) Mouse embryos do not wait for the MBT: Chromatin and RNA polymerase remodeling in genome activation at the onset of development. Dev Genet. 22: 31-42.

Timchenko L. T., Miller J. W., Timchenko N. A., DeVore D. R., Datar K. V., Lin L., Roberts R., Caskey C. T., Swanson M. S. (1996) Nucleic Acids Res. 24: 4407-4414.

Vernet M., Bonnerot C., Briand P., Nicolas J.F. (1992) Changes in permissiveness for the expression of microinjected DNA during the first cleavages of mouse embryos. Mech Dev. 36: $129-139$.

Vogelstein B., Gillespie D. (1979) Preparative and analytical purification of DNA from agarose. Proc Natl Acad Sci U S A. 76: 615-19. 
Wakamatsu Y., Weston J. A. (1997) Sequential expression and role of Hu RNA-binding proteins during neurogenesis. Development. 124: 3449-3460.

Webster P. J., Liang L., Berg C. A., Lasko P., Macdonald P. M. (1997) Translational repressor bruno plays multiple roles in development and is widely conserved. Genes Dev. 11: $2510-2521$.

Whitt G. S., Childers W. F., Cho P. L. (1973) Allelic expression at enzyme loci in an intertribal hybrid sunfish. J Hered. 64:55.

Whitt G. S., Cho P. L., Childers W. F. (1972) Preferential inhibition of allelic isozyme synthesis in an interspecific sunfish hybrid. J Exp ZooL. 179:271.

Wilhelm C. (2001) Der cDNA und des Gens Metr-1 der Maus, einem Vertreter der Brunolike Genfamilie und Analysen zur Expression. Diploma thesis, Institute of Human Genetics, Goettingen

Yao K. M., Samson M. L., Reeves R., White, K. (1993) Gene elav of Drosophila melanogaster: a prototype for neuronal-specific RNA binding protein gene family that is conserved in flies and humans. J. Neurobiol. 24: 723-739.

Yamanchi T., Goldberg E. (1974) Asynchronous expression of glucose-6-phosphate dehydrogenase in splake trout embryos. Dev Biol. 39:63.

Zhang W. H., Han Liu. K., Grabowski P.J. (2002) Region-specific alternative splicing in the nervous system: implications for regulation by the RNA binding protein NAPOR. RNA. 8: $671-685$.

Zhong J., Peters A. H., Kafer K. Braun R. E. (2001). A highly conserved sequence essential for translational repression of the protamine 1 messenger RNA in murine spermatids. Biol Reprod. 64: 1784-1789. 


\section{Publication}

Nayernia K., Nolte J., Michelmann H.W., Lee J. H., Rathsack K., Drusenheimer N., Dev A.,Wulf G., Ehrmann I. E., Elliot D. J., Okpanyi V., Zechner U., Haaf T. Meinhardt A., Engel W. (2006) In vitro-differentiated embryonic stem cells give rise to male gametes that can generate offspring mice. Dev Cell. 11(1): 125-132.

Tseden K., Topaloglu O., Meinhardt A., Dev A., Adham I., Muller C., Wolf S., Bohm D., Schluter G., Engel W., Nayernia K. (2006) Premature translation of transition protein 2 mRNA causes sperm abnormalities and male infertility. Mol Reprod Dev. Epub: 2006, Sep 11. 


\section{ACKNOWLEDGEMENTS}

I would like to express my deepest gratitude to Prof. Dr. W. Engel for his support, encouragement, excellent scientific supervision and financial support for my Ph.D study. It has been a pleasure working in such an inspiring and friendly atmosphere as he has created at the Institute of Human Genetics.

I wish to express my appreciation to Prof. Dr. K. Nayernia for his help during the whole study, interesting discussions, editing my thesis and friendly relationship throughout this study

I sincerely thank PD Dr. S. Hoyer-Fender to be my co-referee. I also extend my sincere thanks to Prof Dr. W. Liebl and Prof Dr. R. Ficner for being my dissertation examiner.

I would like to thank all my institute colleagues for being so friendly and helpful during my stay; for their numerous advices, constant support and fantastic work atmosphere.

I would like to appreciate the current and former members of my lab: Iris, Ewelina, Jae Ho, Lukasz, Christian, Nadja, Jessica, Christina, Britta, Janine, Sandra, Birgit, Harald, Moneef, Irakali, Pandian and Prakasha.

I am glad indeed to my parents, to all my brothers and sisters; and especially to my best friend, Ashok.

Finally, and most importantly, this work would not have been possible without the love and support of my dear wife, Seema, my best friend and closest companion. Thank you for the encouragement and understanding during all those stressful hours. 


\section{Curriculum vitae}

Personals:

Name: $\quad$ Arvind Dev

Date of Birth: $\quad 3^{\text {rd }}$ August 1973

Sex: $\quad$ Male

Nationality: Indian

\section{Academics}

1980-1990:

Primary and High School, UP Board, Meerut, India.

1990-1992: $\quad$ Intermediate, UP Board, Meerut, India.

1992-1995: Bachelor of Science (B.Sc.), C.C.S. University, Meerut, India.

1996-1998: $\quad$ Master of Science (M.Sc.) C.C.S. University, Meerut, India.

2000-2002: $\quad$ M.Tech. (Master of Technology), Indian Institute of Technology (I.I.T.), Kharagpur, India.

Dissertation for M.Tech. Thesis: "Production, purification and characterization of proteolytic enzyme produced by Aspergillus parasiticus."

Since 2002: $\quad$ Doctorate of Philosophy (Ph.D.) Institute of Human Genetics, George August University, Göttingen, Germany.

Dissertation for Ph.D. Thesis: "Expression and functional analysis of murine Brunol1 and Brunol4, members of Elav/Bruno family”. 